\title{
Axial ligand binding equilibria as probes of the effective steric bulk of substituted tetraarylporphyrins
}

\author{
Michael Craig Thomas \\ West Virginia University
}

Follow this and additional works at: https://researchrepository.wvu.edu/etd

\section{Recommended Citation}

Thomas, Michael Craig, "Axial ligand binding equilibria as probes of the effective steric bulk of substituted tetraarylporphyrins" (2004). Graduate Theses, Dissertations, and Problem Reports. 2049.

https://researchrepository.wvu.edu/etd/2049

This Thesis is protected by copyright and/or related rights. It has been brought to you by the The Research Repository @ WVU with permission from the rights-holder(s). You are free to use this Thesis in any way that is permitted by the copyright and related rights legislation that applies to your use. For other uses you must obtain permission from the rights-holder(s) directly, unless additional rights are indicated by a Creative Commons license in the record and/ or on the work itself. This Thesis has been accepted for inclusion in WVU Graduate Theses, Dissertations, and Problem Reports collection by an authorized administrator of The Research Repository @ WVU. For more information, please contact researchrepository@mail.wvu.edu. 


\title{
AXIAL LIGAND BINDING EQUILIBRIA AS PROBES OF THE EFFECTIVE STERIC BULK OF SUBSTITUTED TETRAARYLPORPHYRINS
}

\author{
by \\ Michael Craig Thomas \\ Thesis submitted to the Eberly College of Arts and Sciences \\ at West Virginia University \\ in partial fulfillment of the requirements \\ for the degree of
Master of Science
in
Chemistry

Approved by

Alan M. Stolzenberg, Committee Chairperson Jeffrey L. Petersen

Harry O. Finklea

Bennett Department of Chemistry

Morgantown, West Virginia

2004

Keywords: tetraarylporphyrin, zinc(II) porphyrin, axial ligation Copyright 2004 Michael Craig Thomas 


\section{Abstract \\ AXIAL LIGAND BINDING EQUILIBRIA AS \\ PROBES OF THE EFFECTIVE STERIC \\ BULK OF SUBSTITUTED \\ TETRAARYLPORPHYRINS}

\section{by Michael Craig Thomas}

Equilibrium constants and thermodynamic data are reported for coordination of various axial ligands to the zinc(II) complexes of tetra( $p$-tolyl)porphyrin, tetra(3,5bis(biphenylmethoxy)phenyl)porphyrin, tetra(2,6-(perfluorobenzoxy)phenyl) porphyrin, and tetra(2,6-di(methoxy)phenyl)porphyrin in toluene at $25.0^{\circ} \mathrm{C}$. With respect to coordination of a planar ligand to a zinc(II) porphyrin, the equilibrium constant varied with the identity of the meso-substituent in the order 3,5-bis(biphenylmethoxy)phenyl $>p$-tolyl > 2,6-(perfluorobenzoxy)phenyl >> 2,6-di(methoxy)phenyl. With respect to coordination of a non-planar ligand to a zinc(II) porphyrin, the order was 3,5-bis(biphenylmethoxy)phenyl > p-tolyl >> 2,6(perfluorobenzoxy)phenyl $\approx 2,6-d i($ methoxy)phenyl. Thermodynamic data for the coordination of 3- and 4-phenylpyridine to zinc tetra(2,6-di(methoxy)phenyl) porphyrin show a greater loss of entropy than for the coordination of 3- and 4phenylpyridine to zinc tetra(2,6-(perfluorobenzoxy)phenyl)porphyrin. Space-filling models show that the 2,6-dimethoxy groups of zinc tetra(2,6-di(methoxy)phenyl) porphyrin's four-coordinate form have rotational degrees of freedom as opposed to the rotationally restricted 2,6-perfluorobenzoxy groups of zinc tetra(2,6-(perfluorobenzoxy)phenyl)porphyrin's four-coordinate form. The resulting loss of entropy due to coordination of an axial ligand (which restricts rotation of the mesosubstituents) causes the 2,6-di(methoxy)phenyl groups to, in effect, be more sterically demanding than 2,6-(perfluorobenzoxy)phenyl groups in terms of lower axial ligation equilibrium constants. Also, experimental data suggest that 3,5- 
bis(biphenylmethoxy)phenyl groups at the meso-positions of a metalloporphyrin are no more sterically demanding than $p$-tolyl groups at the meso-positions. 


\section{DEDICATION}

This thesis is dedicated to the loving memory of two family members who left us in the spring of 2002, F. J. Thomas and Judith Rose. 


\section{ACKNOWLEDGMENTS}

First and foremost, I would like to thank Professor Alan M. Stolzenberg for his guidance and support throughout this project. His enthusiasm as my research advisor and thesis committee chair was pivotal in my work. I would also like to thank the other members of my thesis committee: Professor Jeffrey L. Petersen and Professor Harry O. Finklea for their advice and constructive criticism over the course of this process. Additionally, I would also like to acknowledge Professor Robert Nakon for helpful discussions during the early stages of my research.

Although I could never include everyone who deserves to be on this list, I would like to thank those closest to me during the past three years for their unconditional support and encouragement, for without you l'd truly be lost: My parents - Mike and Rhonda Thomas, Brother - A. J. Thomas, Grandmother Helen Thomas, Lauren Klug, Roger Clegg, Mellissa Clegg, Brian Goddard, Chris Meier, William Knight, Timothy Potts, Terrance Marth, and Jack Kaminski.

I would also like to acknowledge West Virginia University and the Greater Kanawha Valley Foundation for their financial support during my time as a graduate student. 


\section{TABLE OF CONTENTS}

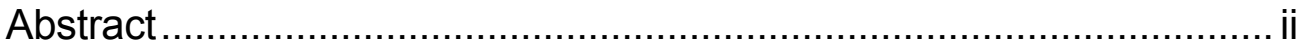



Acknowledgements..................................................................... iv

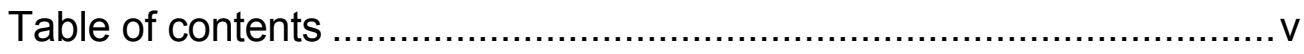

List of Figures ............................................................................ vii

List of Tables............................................................................... ix

List of Symbols / Nomenclature ......................................................

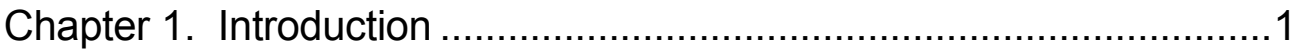

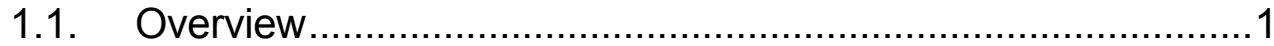

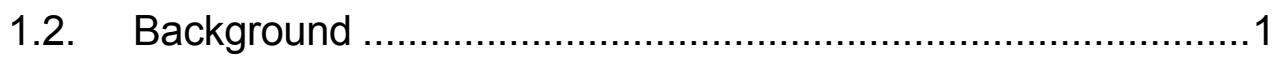

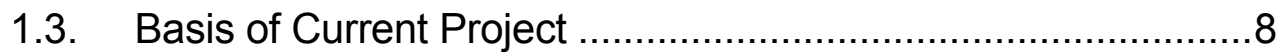

Chapter 2. Preparation of Compounds ...........................................14

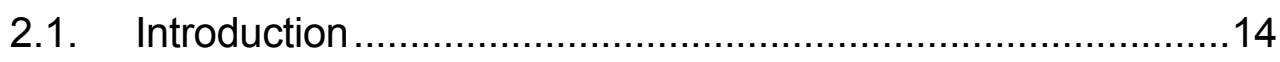



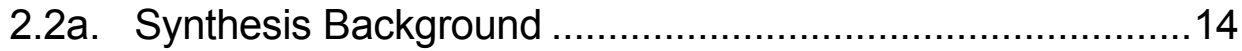

2.2b. Results and Discussion....................................................... 18

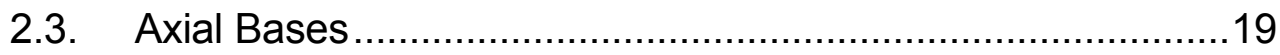



2.3b. Proazaphosphatranes-Background ..................................21

2.3c. Proazaphosphatranes-Results and Discussion ..................22

2.3d. Crystal Structure of $p-M e B z$ Azaphosphatrane Chloride.....24

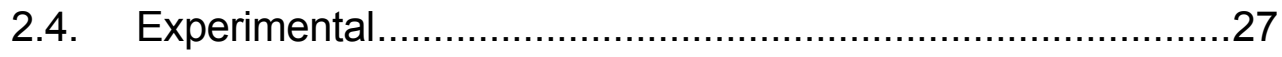

Chapter 3. Ligand Binding Experiments .............................................33

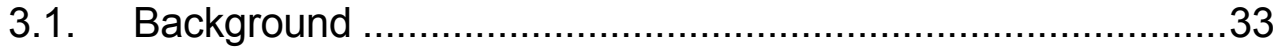

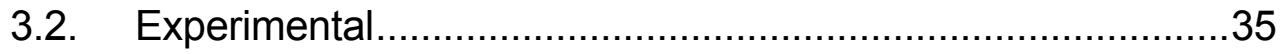

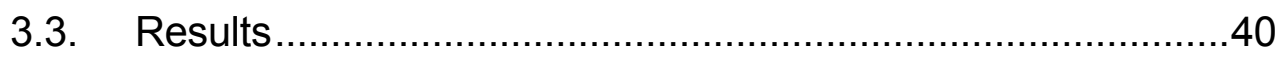

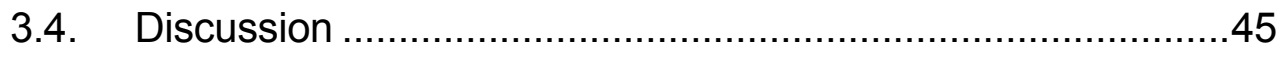

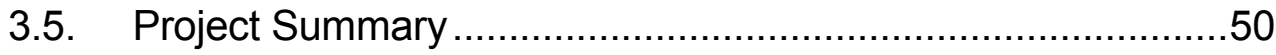


Appendix A - Selected Van't Hoff Plots ............................................52

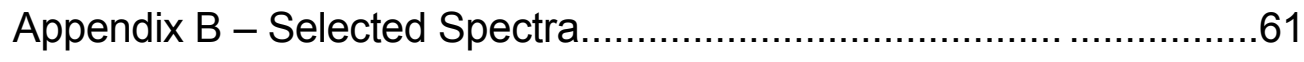

Appendix C - Comparison of Spectra .............................................

Appendix D - SQUAD Program Input File .........................................73

Appendix E - SQUAD Program Output File......................................74

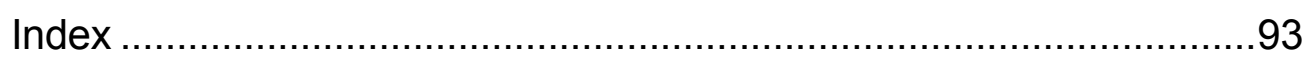




\section{LIST OF FIGURES}

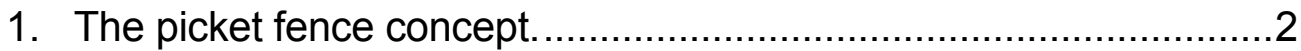

2. Synthesis of meso-tetra(o-aminophenyl)porphyrin..........................

3. Meso-tetra(o-aminophenyl)porphyrin synthesized by Collman and coworkers............................................................

4. Meso-tetra( $\alpha, \alpha, \alpha, \alpha-o-p i v a l a m i d o p h e n y l)$ porphyrin. ........................4

5. Example of the $\mathrm{O}_{2}$ binding $\mathrm{Fe}^{\|}$picket fence porphyrin.................... 4

6. Cyclam and cyclen capped, and TACN capped pyridine tailed pocket porphyrins ..............................................

7. Examples of porphyrins hindered on both faces..........................6

8. Example of a caged porphyrin.................................................. 7

9. Reaction of ( $m$-[G3]TTP)Co" with propargyl alcohol. ......................8

10. $S_{H} 2$ mechanism proposed for alkyl exchange between two cobalt(II) porphyrins. ........................................................

11. 3,5-bis(biphenylmethoxy)phenyl and 3,5-di(methoxy)phenyl

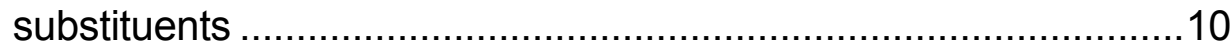

12. Meso-substituted and $\beta$-substituted porphyrins. ......................... 14

13. Adler method of synthesizing meso-substituted porphyrins..........15

14. Oxidation of chlorin impurity in Adler method..............................15

15. Two-step one-flask room temperature synthesis of



16. Modified Lindsey method......................................................... 17

17. Meso-substituents used in current project.................................. 18

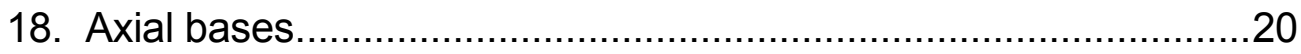

19. General structure of a proazaphosphatrane ..............................21

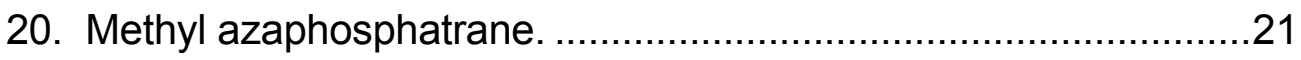

21. Various other azaphosphatrane analogues...............................22

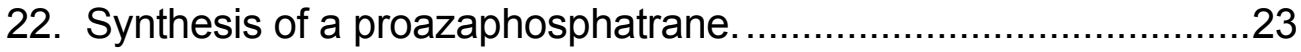


23. ORTEP drawing of the $p$-methylbenzyl azaphosphatrane chloride salt.

24. Example of a set of selected spectra from one temperature in a ligand binding experiment.

25. Plot of $\log K$ vs. $1 / T$ for coordination of 3-phenylpyridine to ZnTTP 40

26. Space-filling models of zinc tetra((2,6-perfluorobenzoxy)phenyl)porphyrin and zinc tetra((2,6-dimethoxy)phenyl)porphyrin.

27. Space-filling models of the coordination of 3-phenylpyridine to zinc tetra((2,6-perfluorobenzoxy)phenyl)porphyrin and zinc tetra((2,6-dimethoxy)phenyl)porphyrin 


\section{LIST OF TABLES}

1. Crystal data and structure refinement for $\left[\mathrm{HPN}\left(\mathrm{CH}_{2} \mathrm{CH}_{2} \mathrm{NCH}_{2} \mathrm{C}_{6} \mathrm{H}_{4} \mathrm{Me}\right)_{3}\right] \mathrm{Cl} \cdot \mathrm{H}_{2} \mathrm{O}$

2. Selected interatomic distances $[\AA]$ and bond angles [ [ ] for [ $\mathrm{HPN}\left(\mathrm{CH}_{2} \mathrm{CH}_{2} \mathrm{NCH}_{2} \mathrm{C}_{6} \mathrm{H}_{4} \mathrm{Me}\right)_{3} \mathrm{Cl} \cdot \mathrm{H}_{2} \mathrm{O}$

3. Equilibrium constants at $25^{\circ} \mathrm{C}$ for coordination of bases by zinc(II) porphyrin complexes in toluene..

4. Enthalpy data for the coordination of bases by zinc(II) porphyrin complexes measured over the range $15-70^{\circ} \mathrm{C}$ in toluene.

5. Entropy data for the coordination of bases by zinc(II) porphyrin complexes measured over the range $15-70^{\circ} \mathrm{C}$ in toluene. 


\section{LIST OF UNCOMMON ABBREVIATIONS}

1. OEP - octaethylporphyrin

2. TTP - tetra( $p$-tolyl)porphyrin

3. T3,5tBuPP - tetra(3,5-bis(t-butyl)phenyl)porphyrin

4. T2,6FBzOPP - tetra(2,6-bis(perfluorobenzoxy)phenyl)porphyrin

5. T2,6MeOPP - tetra(2,6-(dimethoxy)phenyl)porphyrin

6. TBPMPP - tetra(3,5-bis(biphenylmethoxy)phenyl)porphyrin

7. IsobutyIPN3 - isobutyl proazaphosphatrane

8. MethyIPN3 - methyl proazaphosphatrane

9. p-MethylbenzyIPN3 - para-methylbenzyl proazaphosphatrane 


\section{CHAPTER 1: INTRODUCTION}

\subsection{Overview}

Steric hindrance plays an important role in porphyrin and metalloporphyrin chemistry. A sizeable amount of research uses the steric bulkiness of substituted porphyrins to control reactivity and especially to prevent unwanted reactions. In this chapter, we review the literature of important developments in the chemistry of sterically encumbered porphyrins. Chapter 2 describes the synthesis and preparation of compounds used in the project. Finally, the results of the project, a discussion, and concluding remarks are presented in chapter 3 .

\subsection{Background}

Among one of the more important uses of sterically encumbered porphyrins is in modeling $\mathrm{O}_{2}$ binding by iron(II) complexes. The major difficulty in preparing iron(II) dioxygen complexes arises from the rapid irreversible oxidation of iron(II) to iron(III), which affords a $\mu$-oxo di-iron(III) complex, equation $1 .{ }^{1}$

$$
2 \mathrm{Fe}^{\prime \prime}(\mathrm{TTP}) \mathrm{B}_{2} \stackrel{-\mathrm{B}}{\longrightarrow} 2 \mathrm{Fe}^{\prime \prime}(\mathrm{TTP}) \mathrm{B} \stackrel{1 / 2 \mathrm{O}_{2}}{\longrightarrow} \text { (TTP)Fe } \mathrm{Fe}^{\text {III-O}-\mathrm{Fe}}{ }^{\prime \prime \prime}(\mathrm{TTP})+4 \mathrm{~B}
$$

Scheme 1. Irreversible oxidation of FeTTP. B = a coordinated base, TTP = tetra(tolyl)porphyrin. Modified from Reference 1.

Balch and coworkers used low-temperature NMR studies to show that irreversible oxidation begins by two iron(II) porphyrins joining via a peroxo bridge, forming a dimer (equations $2-3$ ). ${ }^{2}$

$$
\begin{gathered}
\mathrm{Fe} \text { IIP }+\mathrm{O}_{2} \leftrightarrow \mathrm{PFeO}_{2} \\
\mathrm{PFeO}_{2}+\mathrm{Fe} \text { III } \longrightarrow \mathrm{PFeO}_{2} \mathrm{FeP}
\end{gathered}
$$

Scheme 2. Formation of the peroxo-bridged dimer $\mathrm{PFeO}_{2} \mathrm{FeP} . \mathrm{P}=$ porphyrin. Reproduced from Reference 2.

Equations 4-8 show the mechanism through which the peroxo-bridged dimer is converted to an oxo-bridged di-iron complex.

$$
\begin{aligned}
& \mathrm{PFe}^{\mathrm{III}} \mathrm{O}_{2} \mathrm{Fe}^{\mathrm{Ill} P} \longrightarrow 2 \mathrm{PFe}^{\mathrm{IV} O}
\end{aligned}
$$

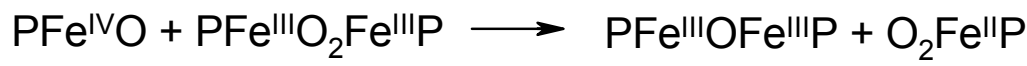




$$
\begin{aligned}
& \mathrm{O}_{2} \mathrm{Fe}^{\mathrm{Il}} \mathrm{P} \leftrightarrow \mathrm{O}_{2}+\mathrm{PFe}^{\|}
\end{aligned}
$$

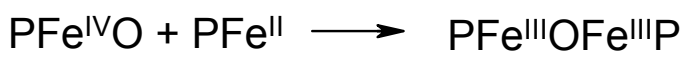

$$
\begin{aligned}
& \mathrm{PFe}{ }^{I V O}+\mathrm{O}_{2} \mathrm{Fe}^{\prime l} \mathrm{P} \longrightarrow \mathrm{PFe} e^{I I I} \mathrm{OFe} e^{I I I I} \mathrm{P}+\mathrm{O}_{2}
\end{aligned}
$$

Scheme 3. Conversion of peroxo-bridged iron" dimer to an oxo-bridged di-iron "II porphyrin species. $\mathrm{P}=$ porphyrin. Reproduced from Reference 2 .

The idea of using sterically encumbered porphyrins to prevent irreversible oxidation was published in $1971 .{ }^{3}$ The porphyrin would simultaneously favor a five-coordinate iron and prevent the irreversible oxidation reaction. The porphyrin to be used should have steric bulk on one side of the porphyrin plane yet should leave the other side open. A bulky ligand, for example an $\mathrm{N}$-alkyl imidazole, would coordinate on the unhindered side of the porphyrin plane. By doing so, the complexation of $\mathrm{O}_{2}$ would be directed to the hindered side of the porphyrin plane. Conceptually, the bulkiness of the porphyrin (Figure 1) would eliminate the possibility of the irreversible oxidation process. ${ }^{3}$

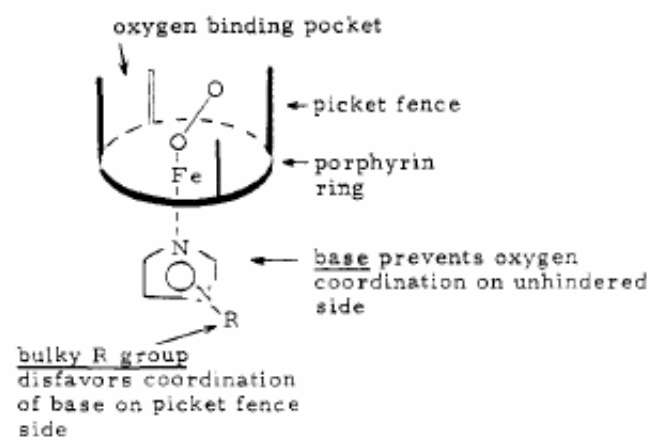

Figure 1. The picket fence concept. Reproduced from Reference 1.

Collman and coworkers first synthesized the picket fence porphyrin in 1974. ${ }^{1}$ Their strategy was to attach bulky groups on one side of a meso-phenyl substituted porphyrin. The precursor to the picket-fence porphyrin was prepared through condensation of $o$-nitrobenzaldehyde and pyrrole followed by reduction of the nitro groups to afford meso-tetra(o-aminophenyl)porphyrin (Figure 2). ${ }^{1}$ 


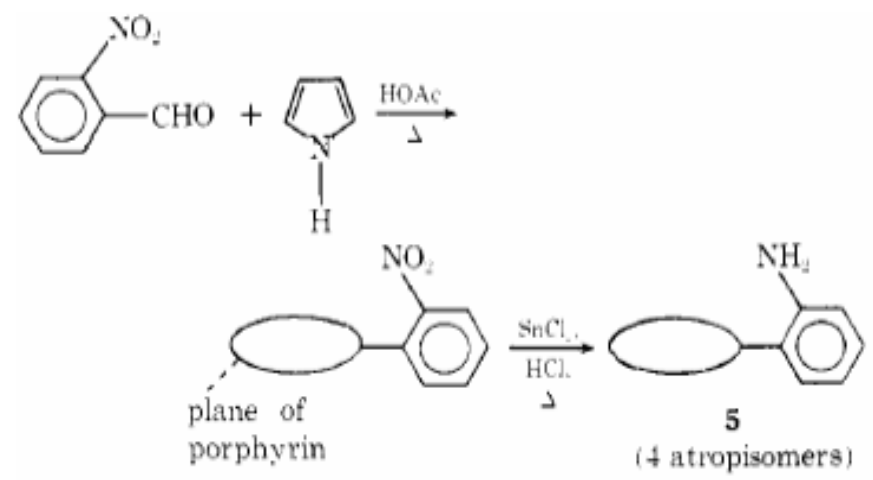

Figure 2. Synthesis of meso-tetra(o-aminophenyl)porphyrin. Only one of the four meso-groups are shown. Reproduced from Reference 1.

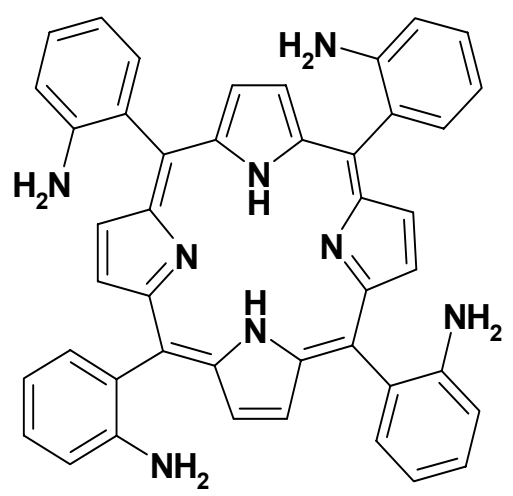

Figure 3. Meso-tetra(o-aminophenyl)porphyrin synthesized by Collman and coworkers.

Due to restricted rotation of the aryl groups, meso-tetra(o-aminophenyl) porphyrin has four atropisomers. Atropisomers are isomers based on each group's location relative to the porphyrin plane. The atropisomer that has all four amine groups on the same side of the porphyrin plane, the $\alpha, \alpha, \alpha, \alpha-f o r m$, was isolated using silica gel chromatography. The remaining three atropisomers reequilibrate to the equilibrium mixture in refluxing toluene. By simply reequilibrating and separating, nearly all of the original meso-tetra(o-aminophenyl)porphyrin product could be converted to the $\alpha, \alpha, \alpha, \alpha-$ form. ${ }^{1}$

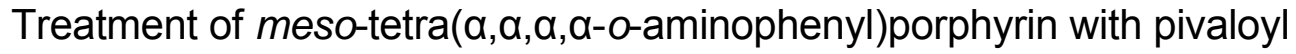
chloride resulted in a porphyrin with four bulky groups on one face. Meso-

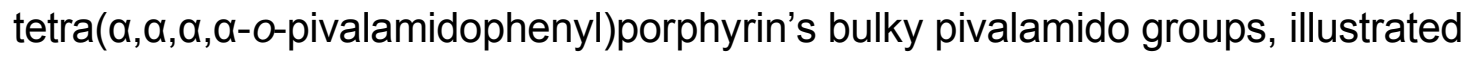
in Figure 4, help to prevent equilibration to form different atropisomers. This 
compound can then be treated with $\mathrm{FeBr}_{2}$ in $\mathrm{THF}$ followed by reduction with $\left[\mathrm{Cr}(\mathrm{acac})_{2}\right]_{2}$ to give the iron(II) porphyrin complex. ${ }^{1}$

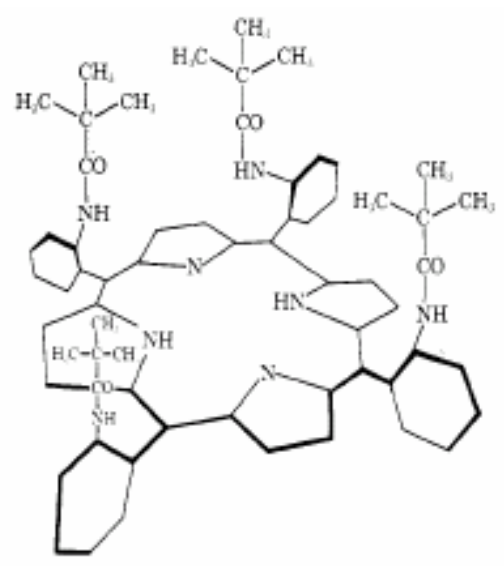

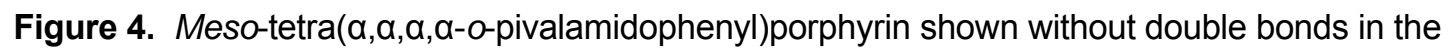
porphyrin macrocycle. Reproduced from Reference 4.

The iron(II) complex formed from meso-tetra( $\alpha, \alpha, \alpha, \alpha-o-p i v a l a m i d o p h e n y l)$ porphyrin will undergo reversible oxygenation in solution at $25^{\circ} \mathrm{C}$, provided that an axial base is present to discourage irreversible oxidation on the open side of the porphyrin. ${ }^{4}$ The picket fence porphyrin (Figure 5) allowed researchers to study models of the interaction of molecular oxygen with hemoproteins. ${ }^{5}$

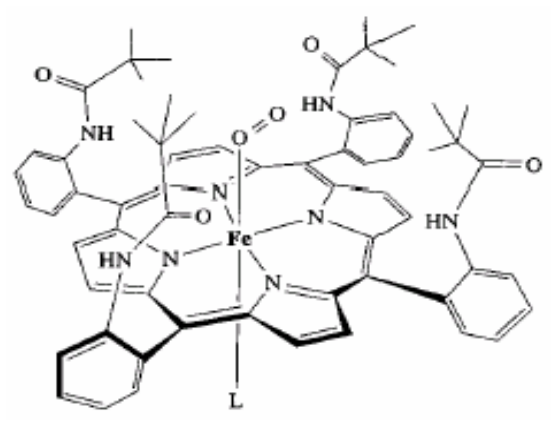

Figure 5. Example of the $\mathrm{O}_{2}$ binding $\mathrm{Fe}$ " picket fence porphyrin. $\mathrm{L}=1$-methylimidazole and 2methylimidazole. Reproduced from Reference 5.

The picket fence porphyrin's affinity towards $\mathrm{O}_{2}$ was similar to that of hemoglobin, but an unexpected feature was that its carbon monoxide affinity was roughly 30 times that of hemoglobin. ${ }^{6}$ Although the picket fence could hinder irreversible oxidation, there was nothing to differentiate $\mathrm{CO}$, which prefers binding in a linear $\mathrm{Fe}-\mathrm{C}-\mathrm{O}$ geometry, from $\mathrm{O}_{2}$, which prefers a bent $\mathrm{Fe}-\mathrm{O}-\mathrm{O}$ 
geometry. The next step in the ongoing process to model $\mathrm{O}_{2}$ binding systems was to place groups above the porphyrin plane to discourage $\mathrm{CO}$ binding, but to still allow $\mathrm{O}_{2}$ binding. This led to the development of capped porphyrins and pocket porphyrins (Figure 6). These porphyrins, which also were built from meso-tetra( $\alpha, \alpha, \alpha, \alpha-o-a m i n o p h e n y l) p o r p h y r i n$, make use of a "cap" to decrease the size of the gas binding cavity. The models allowed the formation of unhindered, bent $\mathrm{FeO}_{2}$ units, while the cap of each model provided steric hindrance to discourage the linear binding of $\mathrm{CO}^{5}$
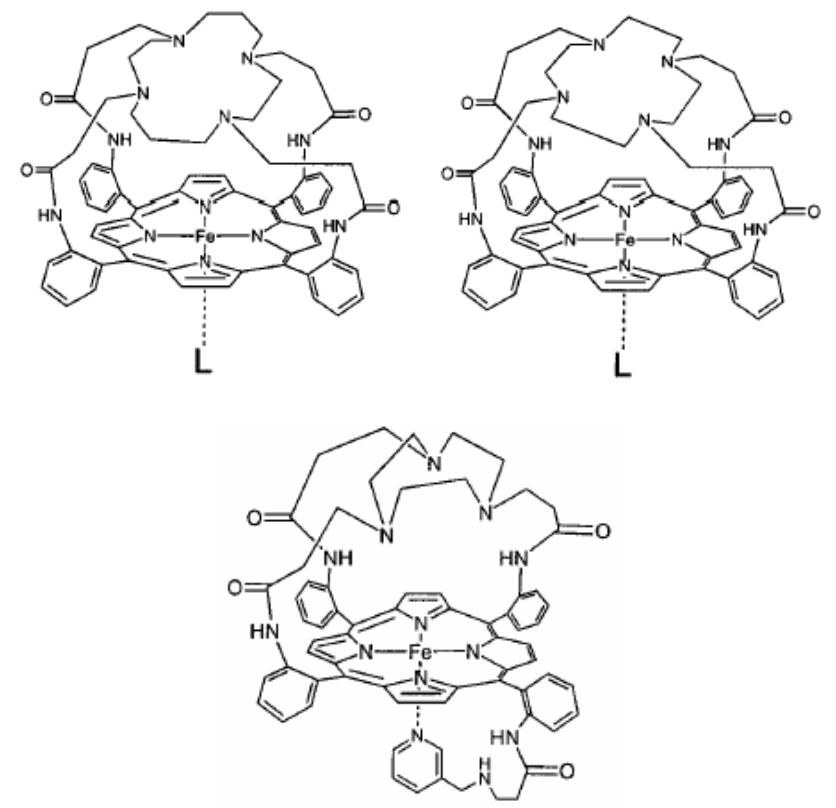

Figure 6. A cyclam (upper left) capped porphyrin, cyclen (upper right) capped porphyrin, and TACN capped pyridine tailed (lower) pocket porphyrin. Reproduced from Reference 5.

Although one-face-hindered porphyrins are probably the best-known systems to prevent formation of the formation of a $\mu$-oxo di-iron(III) complex, ${ }^{7}$ a problem arises in the absence of a coordinating base. With no base to protect the unhindered side of the porphyrin, one-face hindered complexes have a very short lifetime in organic solvents at room temperature because irreversible oxidation can still occur on the unprotected side of the porphyrin. ${ }^{7}$ 
Several groups carried out a newer strategy that placed steric encumbrance on both sides of the porphyrin place in order to prevent bimolecular oxidation but to still allow ligand binding. ${ }^{8}$ Momenteau and coworkers reported that a much better stability towards oxidation of iron(II) porphyrins could be obtained by steric hindrance of both faces of the porphyrin (Figure 7). ${ }^{7}$
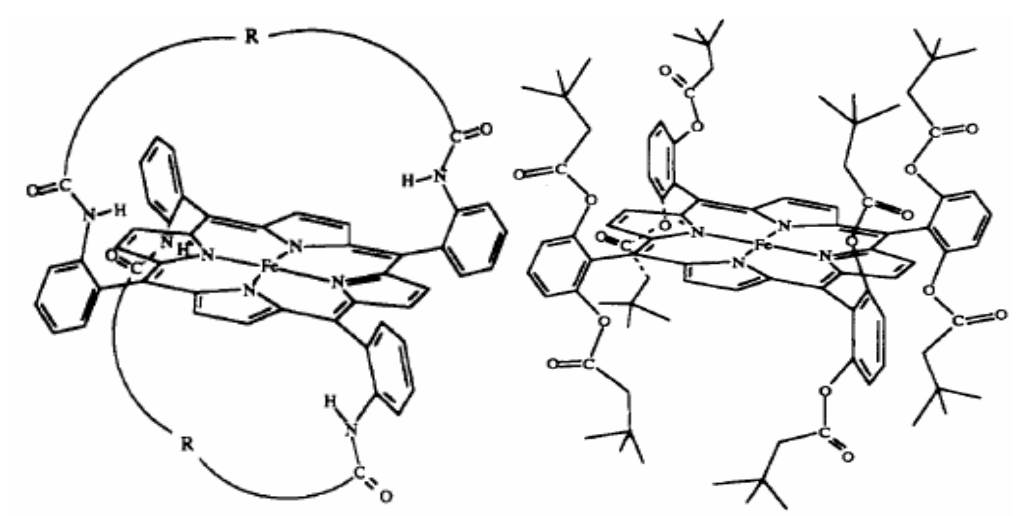

Figure 7. Examples of porphyrins hindered on both faces. Reproduced from Reference 8.

Momenteau and coworkers developed derivatives of 5,10,15,20-

tetraphenylporphyrins in which the two opposite meso-phenyl groups are bridged by a strap (left example in Figure 7). ${ }^{7}$ These porphyrins use the $\alpha, \beta, \alpha, \beta$ atropisomer of meso-tetra(o-aminophenyl)porphyrin to build a strap on each side of the porphyrin plane. Iron(II) complexes of these "basket-handle" porphyrins demonstrated stability against irreversible oxidation, even at room temperature, because of the protection of the straps. ${ }^{7}$

The work by Momenteau and coworkers improved two-face hindered porphyrin model systems by developing an even better basket-handle porphyrin. These include a pyridine or imidazole incorporated into one of the straps. Both the increased local concentration of a coordinating base and the chelate effect of the base now being attached to the macrocycle encourage five-coordination of the metal center. ${ }^{9}$ 
Strapped porphyrins use two meso-groups above and two meso-groups below the porphyrin plane. Models have also been synthesized where each side of the plane has four bulky groups to hinder irreversible oxidation (right example in Figure 7). ${ }^{8}$ Instead of building from amino groups, these porphyrins typically are made from ether groups attached at the ortho-postions of the phenyl ring.

Some of the latest two-face hindered porphyrins built to study biological systems find a metalloporphyrin at the core of a dendrimer. These "caged" porphyrins are constructed in a way that the bulky groups branch out into dendritic groups on each side of the porphyrin plan (Figure 8). These dendritic groups are globular-shaped and are nanoscopic in size. ${ }^{10}$ Caged porphyrins are also used as monomolecular models of dioxygen carrying hemoproteins.

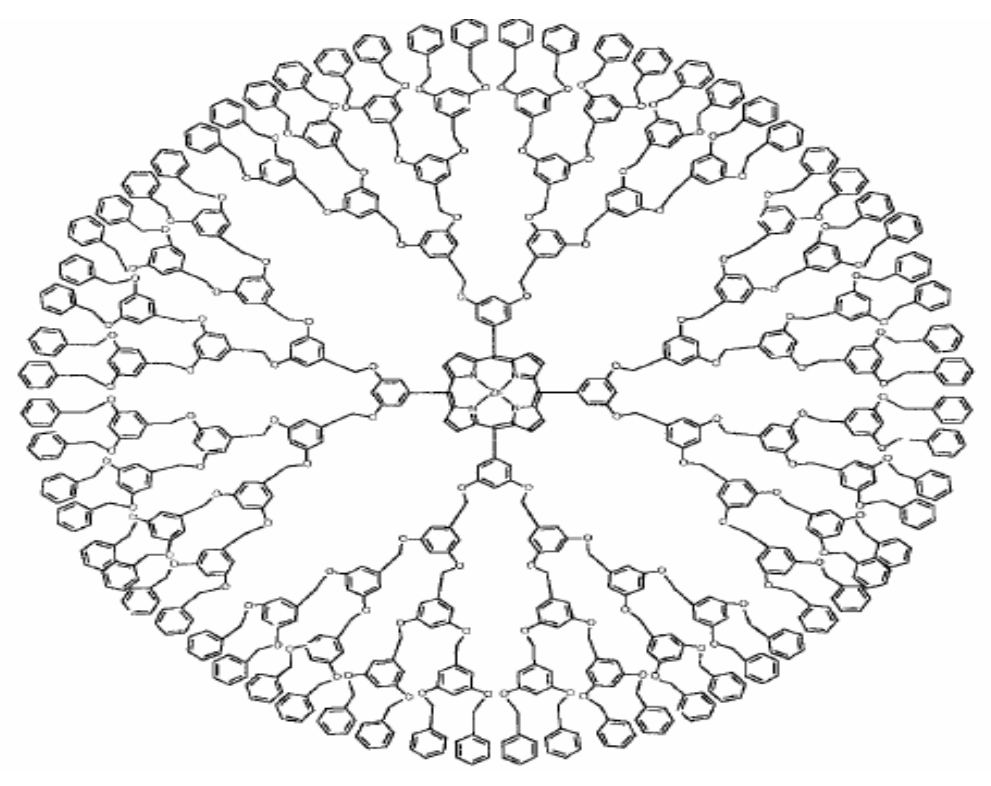

Figure 8. Example of a caged porphyrin. Reproduced from Reference 11.

Caged porphyrins have also demonstrated the ability to control simple organic reactions through sterics. Makoto Uyemura and coworkers succeeded in demonstrating steric control of the AIBN-initiated alkylation of a cobalt(II) porphyrin with propargyl alcohol. The dendritic cage prohibits the access of another cobalt(II) porphyrin, therefore protecting the interior alkylated product from any further isomerization (Figure 9 ). ${ }^{12}$ 




Figure 9. Reaction of (m-[G3]TTP)Co" with propargyl alcohol. Reproduced from Reference 12.

Steric hindrance in porphyrin systems doesn't have to be caused by extremely large groups. The simple o-methoxy groups of iron(II) tetra(2,4,6trimethoxyphenyl)porphyrin do not to allow either oxo- or peroxo- bridged di-iron species to form upon reaction with $\mathrm{O}_{2}$, but irreversible oxidation does occur under similar conditions when $\mathrm{O}_{2}$ is reacted with iron(II) tetra(3,4,5-trimethoxyphenyl)porphyrin. ${ }^{13}$

\subsection{Basis of the Current Project}

In 2001, Stolzenberg and Cao published results of a project using sterics to probe the mechanism of alkyl exchange reactions between organocobalt porphyrins. They established that alkyl exchange reactions proceed through a bimolecular $\mathrm{S}_{\mathrm{H}} 2$ mechanism (Figure 10), in which both metalloporphyrin molecules are simultaneously attached to the alkyl group being transferred in the transition state. ${ }^{14}$
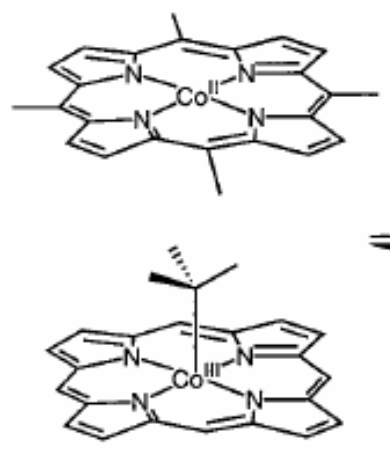

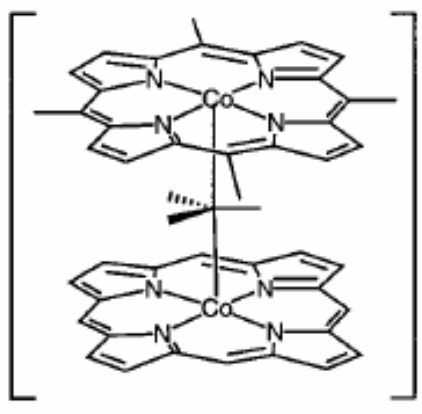

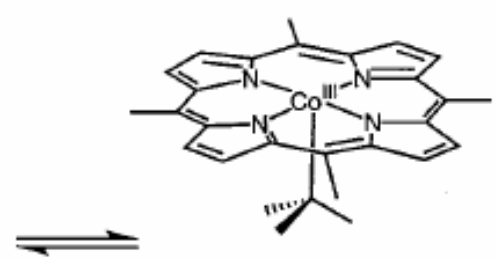



Figure 10. $\mathrm{S}_{\mathrm{H}} 2$ mechanism proposed for alkyl exchange between two cobalt(II) porphyrins. Reproduced from Reference 14. 
One aspect of the research done involved the use of sterically bulky porphyrins to stop alkyl exchange. An important requirement of these experiments was the porphyrins to be used had to be sterically bulky on both sides since alkyl exchange can occur at either face of a metalloporphyrin. ${ }^{14}$ The porphyrins used were derived from disubstituted benzaldehyde precursors.

The rates of alkyl exchanges using various sterically hindered porphyrins were compared to that between $\mathrm{Co}(\mathrm{OEP}) \mathrm{CH}_{3}$ and $\mathrm{Co}(\mathrm{TTP})$. Alkyl exchange between $\mathrm{Co}(\mathrm{OEP}) \mathrm{CH}_{3}$ and $\mathrm{Co}(\mathrm{TTP})$ reached equilibrium in approximately 20 minutes. Under comparable conditions, the exchange reaction between $\mathrm{Co}(\mathrm{OEP}) \mathrm{CH}_{3}$ and $\mathrm{Co}(\mathrm{T} 3,5 \mathrm{tBuPP})$ reached equilibrium in about 1 hour. ${ }^{14}$ This showed evidence of sterics affecting alkyl exchange reaction rates. Substituents at the ortho-positions had a large effect on the rate of alkyl exchange. Exchange between $\mathrm{Co}(\mathrm{OEP}) \mathrm{CH}_{3}$ and $\mathrm{Co}(\mathrm{T} 2,6 \mathrm{MeOPP})$ reached equilibrium after about 2 hours. ${ }^{14}$

Another ortho-substituent showed even more of an ability to affect alkyl exchange reaction rates. The ortho-perfluorobenzoxy groups of $\mathrm{Co}(\mathrm{T} 2,6 \mathrm{FBzOPP})$ were bulky enough that no evidence of alkyl exchange with $\mathrm{Co}(\mathrm{TTP}) \mathrm{CH}_{3}$ could be detected after 19.5 days. ${ }^{14}$

Stolzenberg and Cao also examined alkyl exchange using a porphyrin that had 3,5-bis(biphenylmethoxy)phenyl groups. The results suggested that these groups provided no greater effective steric bulk than 3,5-(methoxy)phenyl groups (Figure 11). The effective steric equivalence of 3,5-bis(biphenylmethoxy) phenyl and 3,5-(methoxy)phenyl groups was unexpected. 


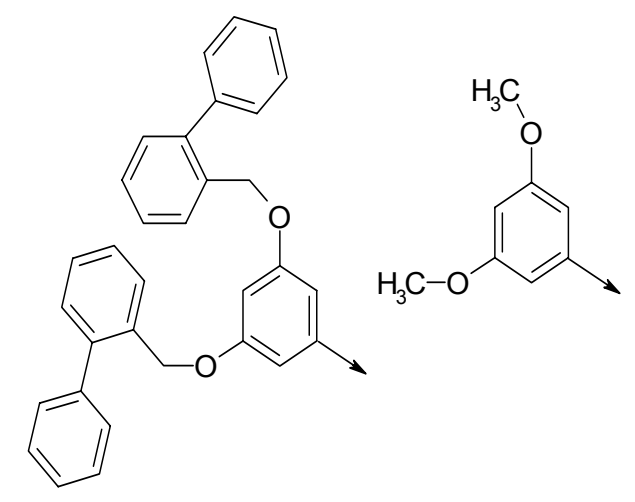

Figure 11. 3,5-bis(biphenylmethoxy)phenyl, 1 above, and 3,5-di(methoxy)phenyl, 2 above. The arrows indicate connection at the meso-position of the porphyrin.

The results discussed are completely consistent with an $\mathrm{S}_{\mathrm{H}} 2$ mechanism for the thermal alkyl exchange reactions between cobalt porphyrins assuming that the 3,5-bis(biphenylmethoxy)phenyl groups swing away and are directed outward from the area above the metal center.

The goal of our recent project was to check the above assumption that the 3,5-bis(biphenylmethoxy)phenyl groups are directed away from the metal center, and to investigate the effective steric bulk of other meso-substituents on metalloporphyrins. Axial ligand binding was used as the probing tool. This allowed the area above the porphyrin plane to be sampled. Unlike in the Stolzenberg/Cao project, zinc(II) porphyrins were used instead of cobalt(II) porphryins. The use of zinc rather than cobalt or iron has three advantages. First, irreversible oxidation can't occur because zinc has no other accessible oxidation states. This eliminates complications due to redox chemistry. Second, zinc(II) porphyrins are known to only coordinate a single axial ligand to form a five-coordinate complex with a 1:1 stoichiometry in solution. ${ }^{15}$ In contrast, cobalt(II) porphyrins can coordinate a second axial ligand in a few cases and iron(II) porphyrins prefer two axial ligands. ${ }^{16}$ Third, equilibrium constants are 
higher for zinc complexes relative to cobalt and iron. Thus, unlike the case for cobalt or iron, a decreased $K_{\text {eq }}$ will still be large enough to be measured. 


\section{References from Chapter 1}

1. Collman, J. P.; Gagne, R. R.; Reed, C. A.; Halbert, T. R.; Lang, G.; Robinson, W. T. ''Picket Fence Porphyrins.' Synthetic Models for Oxygen Binding Hemoproteins." J. Am. Chem. Soc., 1975, 97, 14271439.

2. Chin, D. -H.; La Mar, G. N.; Balch, A. L. "On the Mechanism of Autoxidation of Iron(II) Porphyrins. Detection of Peroxo-Bridged Iron(III) Porphyrin Dimer and the Mechanism of Its Thermal Decomposition to the Oxo-Bridged Iron(III) Dimer." J. Am. Chem. Soc., 1979, 102, 4344-4350.

3. Diekmann, H.; Chang, C. K.; Traylor, T. G. "Cyclophane Porphyrin." J. Am. Chem. Soc., 1971, 93, 4068-4070.

4. Collman, J. P.; Gagne, R. R.; Reed, C. A. "A Paramagnetic Dioxygen Complex of Iron(II) Derived from a 'Picket Fence' Porphyrin. Further Models for Hemoproteins." J. Am. Chem. Soc., 1974, 96, 2629-2631.

5. Collman, J. P.; Hermann, P. C.; Fu, L.; Eberspacher, T. A.; Eubanks, M.; Boitrel, B.; Hayoz, P.; Zhang, X.; Brauman, J. I.; Day, V. W. "Aza-CrownCapped Porphyrin Models of Myoglobin: Studies of the Steric Interactions of Gas Binding." J. Am. Chem. Soc., 1997, 119, 3481-3489.

6. Collman, J. P.; Brauman, J. I.; Iverson, B. L., Sessler, J. L.; Morris, R. M.; Gibson, Q. H. "Dioxygen and Carbonyl Binding to Iron(II) Porphyrins: A Comparison of the 'Picket Fence' and 'Pocket' Porphyrins." J. Am. Chem. Soc., 1983, 105, 3052-3064.

7. Momenteau, M.; Mispelter, J.; Loock, B.; Bisagni, E. "Both-faces Hindered Porphyrins. Part 1. Synthesis and Characterization of Baskethandle Porphyrins and Their Iron Complexes." J. Chem. Soc., Perkin Trans. 1, 1983, 189-196.

8. Momenteau, M.; Reed, C. A. "Synthetic Heme Dioxygen Complexes." Chem. Rev., 1994, 94, 659-698. 
9. Momenteau, M.; Mispelter, J.; Loock, B.; Lhoste, J. "Both-faces Hindered Porphyrins. Part 2. Synthesis and Characterization of internally Five-coordinated Iron(II) Basket-handle Porphyrins derived from 5,10,15,20Tetrakis(o-hydroxyphenyl)porphyrin." J. Chem. Soc., Perkin Trans. 1, 1985, 61-70.

10. Jiang, D. -L.; Aida, T. "A Dendritic Iron Porphyrin as a Novel Haemoprotein Mimic: Effects of the Dendrimer Cage on Dioxygenbinding Activity." J. Chem. Soc., Chem. Comm., 1996, 1523-1524.

11. Pollak, K. W.; Sanford, E. M.; Frechet, J. M. J. "A Comparison of Two Convergent Routes for the Preparation of Metalloporphyrin-core Dendrimers: Direct Comparison vs. Chemical Modification." J. Mat. Chem., 1998, 8, 519-527.

12. Uyemura, M.; Aida, T. "Steric Control of Organic Transformation by a Dendrimer Cage: Organocobalt Dendrimer Porphyrins as Novel Coenzyme $B_{12}$ Mimics." J. Am. Chem. Soc., 2002, 124, 11392-11403.

13. Latos-Grazynski, L.; Cheng, R. -J.; La Mar, G. N.; Balch, A. L. "Oxygenation Patterns for Substituted Meso-Tetraphenylporphyrin Complexes of Iron(II). Spectroscopic Detection of Dioxygen Complexes in the Absence of Amines." J. Am. Chem. Soc., 1982, 104, 5992-6000.

14. Stolzenberg, A. M.; Cao, Y. "Alkyl Exchange Reactions of Organocobalt Porphyrins. A Bimolecular Homolytic Substitution Reaction." J. Am. Chem. Soc., 2001, 123, 9078-9090.

15. D'Souza, F.; Deviprasad, G. R.; Zandler, M. E. "Aggregation and Axial Ligand Exchange Behavior of Water-soluble Pyrrole- $\exists$ Brominated Porphyrins." J. Chem. Soc., Dalton Trans, 1997, 3699-3703.

16. Lawson, D. M.; Stevenson, C. E. M.; Andrew, C. R.; Eady, R. R. "Unprecedented Proximal Binding of Nitric Oxide to Heme: Implications for Guanylate Cyclase." EMBO J., 2000, 19, 5661-5671. 


\section{CHAPTER 2: PREPARATION OF COMPOUNDS}

\subsection{Introduction}

This chapter discusses the preparation of compounds used in the project. It is split into two sections, one on porphyrins and metallopophyrins, and one on axial bases.

There are two types of synthetic porphyrins: meso-substituted and $\exists-$ substituted (refer to Figure 12). Each requires different methods of synthesis. This investigation used only meso-substituted porphyrins. Therefore, only that type will be discussed.

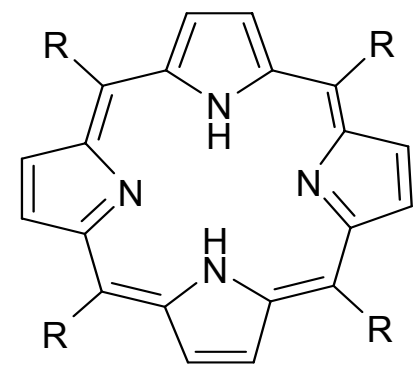

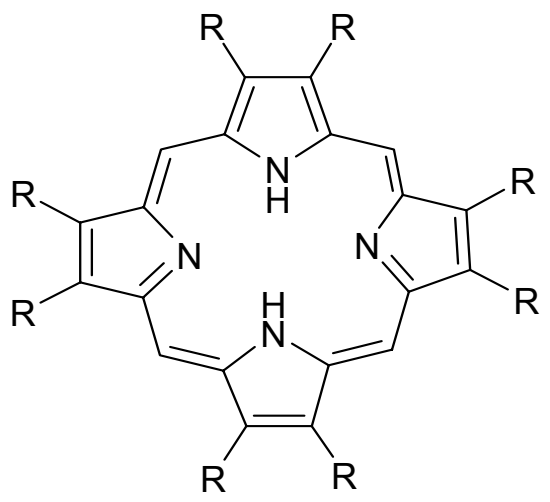

Figure 12. Meso-substituted (left) and $\beta$-substituted (right) porphyrins.

\subsection{Porphyrins}

\section{2a. Synthesis Background}

The Adler method (Figure 13) of synthesizing meso-substituted porphyrins was developed in the mid-1960's. ${ }^{1}$ Adler found that a high concentration of pyrrole and the appropriate aldehyde ( $0.27 \mathrm{M}$ each) could be reacted in aerobic propionic acid. ${ }^{1}$ The most attractive aspect of the Adler method over earlier methods, such as the Rothemund method, is the ease of isolation of the product. Porphyrin products formed under Adler conditions typically crystallize as the reaction mixture cools. The crystals can be isolated via filtration and washing. This method gives poor results if the porphyrin product does not crystallize. 
Hindered aldehydes give a large amount of side product(s) in the form of tars that hinder crystallization and isolation.

4
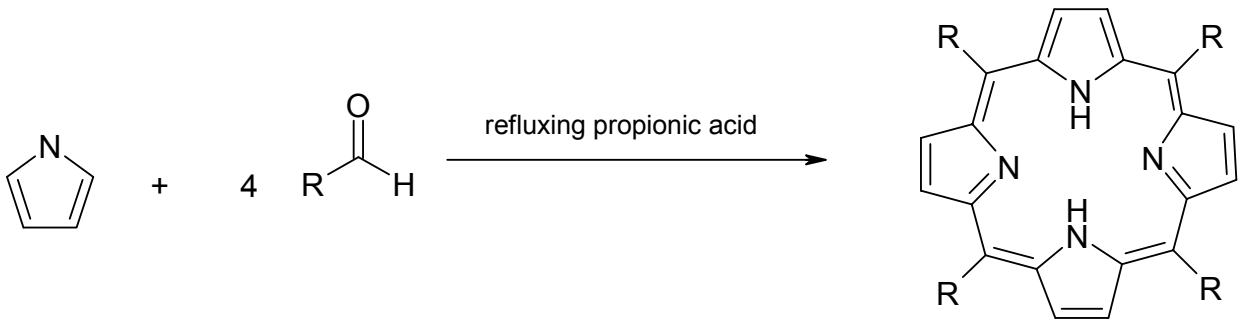

Figure 13. Adler method of synthesizing meso-substituted porphyrins. Reproduced from Reference 1.

The crystalline porphyrin product obtained from the Adler method is contaminated with chlorin $(2-10 \%) .{ }^{2}$ The chlorin impurity can either be eliminated through chromatography or be oxidized with DDQ in refluxing toluene as shown in Figure $14 .^{3}$

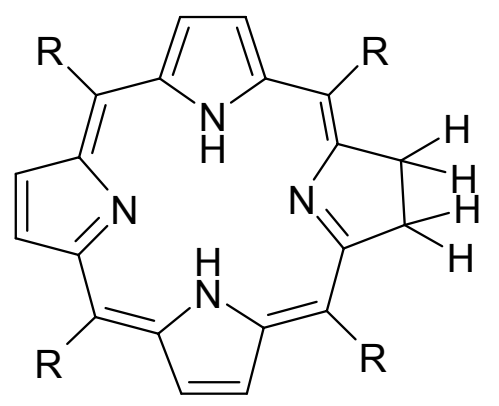

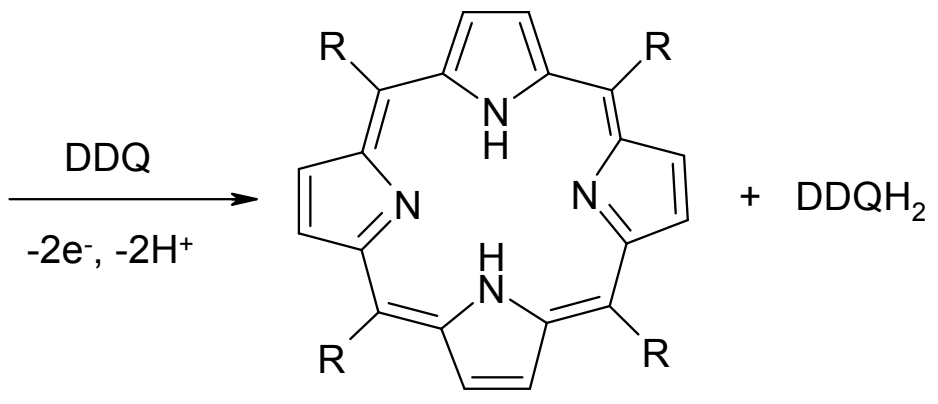

a meso-substituted chlorin

Figure 14. Oxidation of chlorin impurity in Adler method. Modified from Reference 3. Jonathan Lindsey developed a milder process of preparing mesosubstituted porphyrins in the early 1980's to broaden the range of available porphyrin model systems. The Lindsey reaction scheme consists of two steps: condensation in the presence of a catalyst and oxidation of the resulting porphyrinogen to a porphyrin (Figure 15). This method tolerates hindered aldehydes by achieving equilibrium during condensation and avoiding premature oxidation of intermediates and other tar-forming side reactions. ${ }^{4}$ 


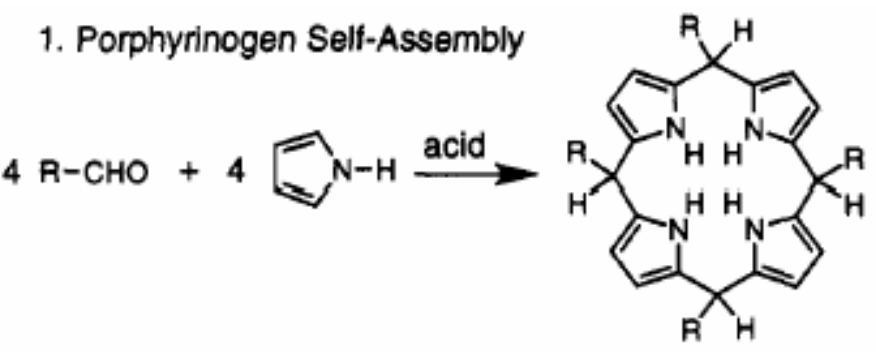

2. Porphyrinogen Oxidation

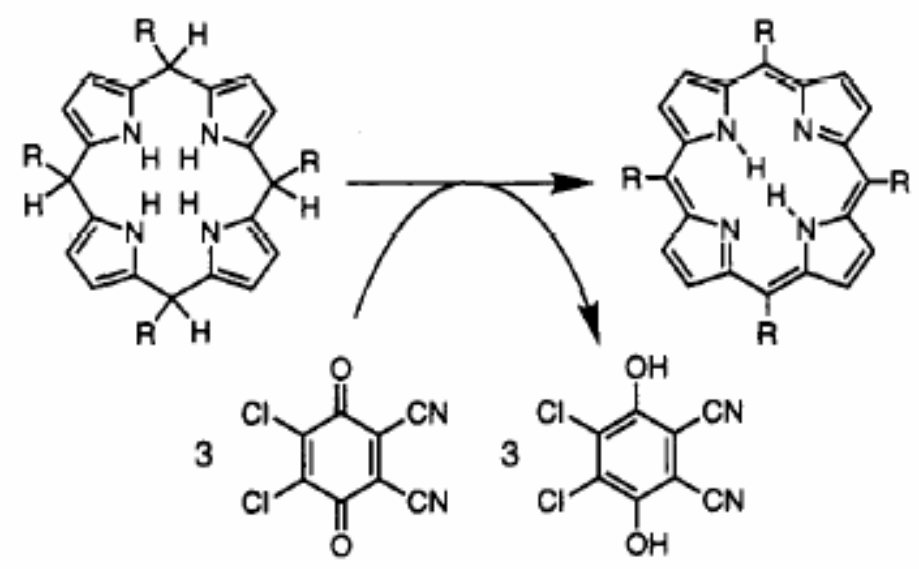

Figure 15. Two-step one-flask room temperature synthesis of meso-substituted porphyrins developed by Lindsey. The catalyst shown is DDQ. Reproduced from Reference 4.

The Lindsey method is a high dilution method, which is a disadvantage with respect to the Adler method. Yields are higher using the Lindsey method but comparable throughput requires a much larger reaction volume and solvent consumption. Maximum yields using the Lindsey method are obtained when the pyrrole and aldehyde concentrations are just $10 \mathrm{mM}$ each. Concentrations either higher or lower drastically decrease the percent yield. ${ }^{5}$ Also, anhydrous conditions are required to form the porphyrinogen. Therefore water levels in solvents and reactants must be controlled.

Another drawback of this method is that hydroquinone is present in stoichiometric quantities and must be separated from the porphyrin product. Lindsey's method was modified into a catalytic cycle. The catalyst, iron(II) phthalocyanine $\left[\mathrm{Fe}^{\prime \prime}(\mathrm{Pc})\right]$, is used for its ability to reoxidize the hydroquinone byproduct back to quinone. This extension of the Lindsey method (Figure 16) only calls for $5 \mathrm{~mol} \%$ each of the quinone and the $[\mathrm{Fe} / \mathrm{Pc})]$ as reactants. After a 
set condensation period, the solution is oxidized aerobically by bubbling a steady stream of air through the mixture. ${ }^{4}$ The catalytic method allows reactions to be successful at higher concentration by decreasing the amount of oxidant that needs to be used and then separated.

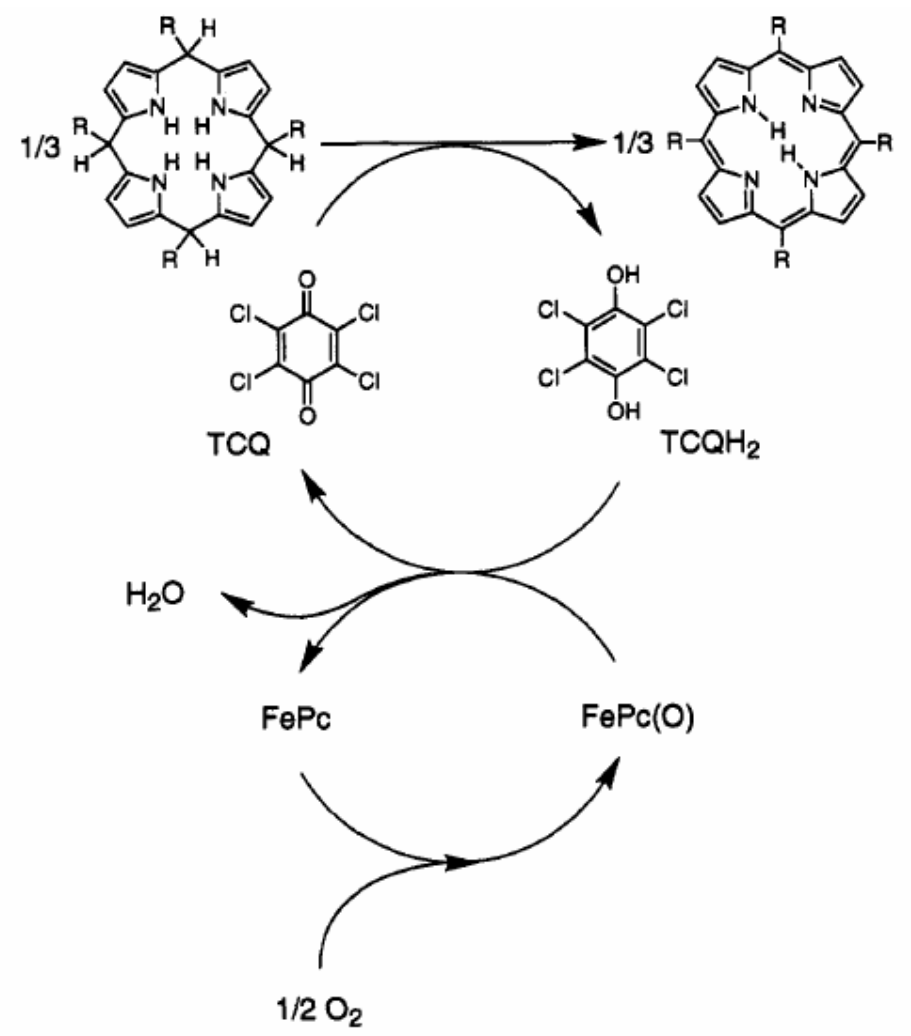

Figure 16. Modified Lindsey method. The catalyst shown is TCQ. Reproduced from Reference 4.

Metallation of a free-base porphyrin to the corresponding zinc(II) porphyrin is a straightforward process. A zinc(II) porphyrin can be obtained by refluxing the free-base porphyrin, excess zinc acetate, and excess sodium acetate in acetic acid overnight. The product can be isolated by collecting on a frit, then washing with water. 


\section{2b. Results and Discussion}

Four different meso-substituted zinc porphyrins were used in this project. Figure 17 displays each meso-substituent: $p$-tolyl, 1, 3,5-bis(biphenylmethoxy)phenyl, 2, 2,6-bis(perfluorobenzoxy)phenyl, 3, and 2,6-di(methoxy)phenyl, 4.

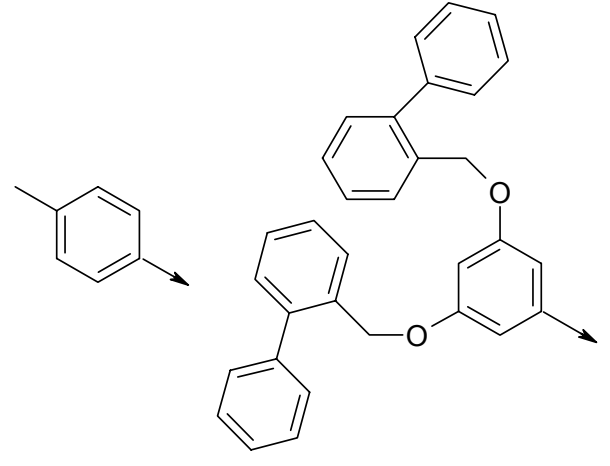

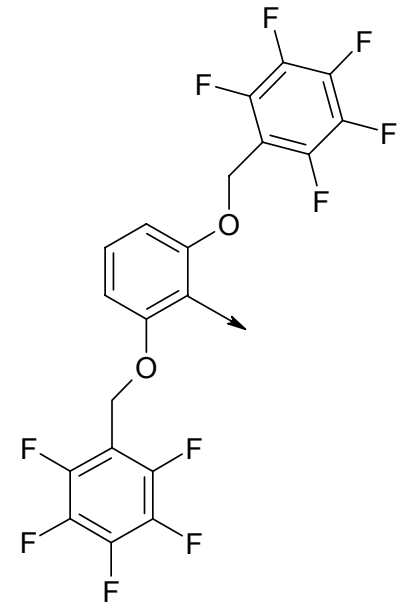

3

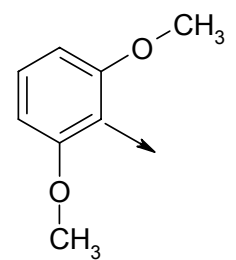

4

Figure 17. Meso-substituents used in the current project. The arrows indicate the connection to the meso-carbon of the porphyrin compound.

Tetra( $p$-tolyl)porphyrin was prepared from pyrrole and $p$-tolualdehyde using the Adler method. ${ }^{6}$ After cooling to room temperature, the crude product was collected by filtration, and washed with methanol to afford tetra(p-tolyl) porphyrin in a $23 \%$ yield. Tetra(3,5-bis(biphenylmethoxy)phenyl)porphryin was prepared by Mike Martinelli by first preparing tetra(3,5-dimethoxyphenyl) porphyrin through condensation of 3,5-dimethoxybenzaldehyde and pyrrole. The tetra(3,5-dimethoxyphenyl)porphyrin was demethylated with boron tribromide to give tetra(3,5-dihydroxyphenyl)porphyrin, then alkylated with 2-phenylbenzylbromide in DMF to give tetra(3,5-bis(biphenylmethoxy)phenyl)porphyrin. This was purified by prep TLC. Tetra(2,6-dimethoxyphenyl)porphyrin was prepared by Yang Cao from pyrrole and 2,6-methoxybenzaldehyde using the uncatalyzed Lindsey method. ${ }^{7}$ Tetra(2,6-perfluorobenzoxyphenyl)porphyrin was a gift from Jonathan Lindsey. It was prepared by an analogous method to the preparation of tetra(3,5-bis(biphenylmethoxy)phenyl)porphyrin discussed above. 
The zinc(II) complexes of the above porphyrins were prepared following literature methods. ${ }^{8}$ Zinc tetra(p-tolyl)porphyrin and zinc tetra(3,5-bis(biphenylmethoxy)phenyl)porphyrin were prepared by Jenna Jurich. Zinc tetra(p-tolyl) porphyrin was recrystallized from chloroform/methanol. Zinc tetra((2,6perfluorobenzoxy)phenyl)porphyrin and zinc tetra((2,6-dimethoxy)phenyl) porphyrin were prepared in $90 \%$ and $91 \%$ yields respectively by refluxing the free-base porphyrin form in acetic acid in the presence of excesses of zinc acetate and sodium acetate. No recrystallization attempts were successful for zinc tetra(3,5-bis(biphenylmethoxy)phenyl)porphyrin, zinc tetra(2,6-bis(perfluorobenzoxy)phenyl)porphyrin, or zinc tetra((2,6-dimethoxy)phenyl)porphyrin.

\subsection{Axial Bases}

\section{3a. Axial Bases-Discussion}

The axial bases used in the project were chosen due to their bulkiness that would be directed toward the meso-groups of the zinc porphyrins while bound. The systems also needed to have binding constants large enough to measure.

The bases fit into two general groups. The first group consisted of planar molecules, that being bases whose third dimension is only the size of an atom. The planar bases chosen were 4-phenylpyridine, 3-phenylpyridine, quinoline, and 1,10-phenanthroline. Ortho-substituted pyridines couldn't be used because the substituent would be directed towards the porphyrin plane and would interfere with binding.

The second group of bases were cone-shaped (bases are shown in Figure 18). Cone-shaped amines could not be used because the $\mathrm{R}$ groups would project toward the metal and stop coordination. Although triphenylphosphine was studied, trialkylphosphines were not studied due to their air sensitivity and noxious odor. Triisopropylphosphite, triphenylphosphite, and tris(2,4-di-t-butylphenyl)phosphite were used due to their bulky $\mathrm{R}$ groups. We also wanted to use cone-shaped structures that were rigid compared to the other three-dimensional bases. We turned to proazaphosphatranes (Section 2.2b). 
Proazaphosphatranes are rigid and their $\mathrm{R}$ groups (Figure 19) should be directed towards the meso-groups of the zinc porphyrins while bound.<smiles>c1ccc(-c2ccncc2)cc1</smiles><smiles>CC(C)OP(OC(C)C)OC(C)C</smiles><smiles>CC(C)(C)c1ccc(OP(Oc2ccc(C(C)(C)C)cc2C(C)(C)C)Oc2ccc(C(C)(C)C)cc2C(C)(C)C)c(C(C)(C)C)c1</smiles>

Figure 18. Axial bases (not including proazaphosphatranes): 4-phenylpyridine, 3-phenylpyridine, quinoline, 1,10-phenanthroline, triisopropylphosphite, triphenylphosphite, triphenylphosphine, and tris(2,4-di-t-butylphenyl)phosphite. 


\section{3b. Proazaphosphatranes-Background}<smiles>[R]N1CCN2CCN([R])P1N([R])CC2</smiles>

Figure 19. General structure of a proazaphosphatrane.

Proazaphosphatranes are a class of nonionic bases first synthesized by Verkade and coworkers at lowa State University. ${ }^{9}$ These bases have been used as catalysts and promoters for many reactions: the trimerization of isocyanates, the dehydrohalogenation of alkyl halides, the transesterification of esters, the deprotection of acylated alcohols and silylated alcohols, Michael additions, the silylation of hindered alcohols, the conjugation of methylene-interrupted double bonds, the synthesis of $\alpha, \beta$-unsaturated nitriles, $\beta$-hydroxy nitriles, homoallylic alcohols, $\beta$-nitroalkanols, $\alpha, \alpha$-dicyano- $\alpha, \beta$-olefins, glutaronitriles, benzofurans, and oxazolines ${ }^{9}$.

Proazaphosphatranes are described as "superbases"10 due to the unusually high Lewis basicity of the phosphorus atom. ${ }^{11}$ The methyl version $(R=$ $\mathrm{CH}_{3}$ in Figure 19) can deprotonate weak acids such as $\mathrm{PhOH}\left(\mathrm{pK} K_{\mathrm{a}}=10\right)$, $(\mathrm{CN})_{2} \mathrm{CH}_{2}\left(\mathrm{p} K_{\mathrm{a}}=11\right)$, protonated Proton Sponge $\left(\mathrm{p} K_{\mathrm{a}}=12.3\right),(\mathrm{EtOOC})_{2} \mathrm{CH}_{2}\left(\mathrm{p} K_{\mathrm{a}}=\right.$ $13)$, and $\mathrm{H}_{2} \mathrm{O}\left(\mathrm{pK} \mathrm{K}_{\mathrm{a}}=15.7\right)$ to give to the methyl azaphosphatrane shown in Figure $20 .{ }^{12}$

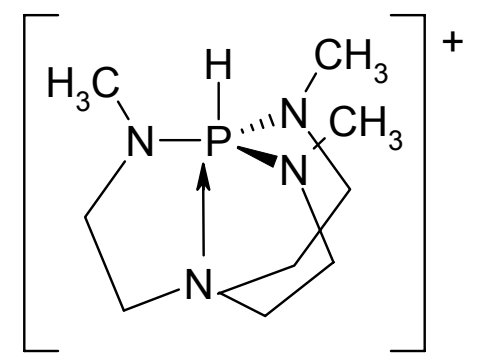

Figure 20. Methyl azaphophatrane.

The high basicity of proazaphosphatranes arises from the ability to form a transannular bond (arrow in Figure 20) between the phosphorus and the 
bridgehead nitrogen. ${ }^{13}$ The transannular bond forms a five-coordinate phosphorus species, ${ }^{11}$ with an upward pyrimidization of the bridgehead nitrogen towards the phosphorus. ${ }^{14}$ Various other systems have been prepared where a transannular bond exists between phosphorus and the bridgehead nitrogen.

Examples (Figure 21) include phosphorus bound to selenium, oxygen, and sulfur, ${ }^{15}$ as well as platinum, rhenium, and mercury, ${ }^{11}$ and boron. ${ }^{16}$



Figure 21. Various other azaphosphatrane analogues. $\mathrm{A}=\mathrm{Se}, \mathrm{O}, \mathrm{S}, \mathrm{Pt}, \mathrm{Re}, \mathrm{Hg}$, or $\mathrm{B}$.

\section{3c. Proazaphosphatranes-Results and Discussion}

Three proazaphosphatranes were used in my project: $R=$ =methyl, isobutyl, and $p$-methylbenzyl (refer to Figure 19). Synthesis of proazaphosphatranes is a three-step process (Figure 22). First, a substituted tetraamine is formed by condensation of the appropriate aldehyde and tris(2-aminoethyl)amine, followed by reduction with sodium borohydride. After purification, the substituted tetraamine is reacted with $\mathrm{CIP}\left(\mathrm{NMe}_{2}\right)_{2}$ to afford the protonated azaphosphatrane chloride salt. Finally, the protonated chloride is deprotonated with a strong base to give the proazaphosphatrane. ${ }^{10}$



Figure 22. Synthesis of a proazaphosphatrane. Modified from Reference 9. 
The previously unknown proazaphosphatrane with $\mathrm{R}=p$-methylbenzyl, was used in this project. The synthesis of $\mathrm{N}\left(\mathrm{CH}_{2} \mathrm{CH}_{2} \mathrm{NHCH}_{2} \mathrm{C}_{6} \mathrm{H}_{4} \mathrm{CH}_{3}\right)_{3}$ was achieved by stirring a 1:4 mixture of tris(2-aminoethyl)amine and $p$-tolualdehyde, then reducing with sodium borohydride. The excess aldehyde results in the presence of an impurity, $p$-methylbenzyl alcohol. This was removed from the tetraamine using a Kugelrohr distillation apparatus. We were unable to remove the $p$-methylbenzyl alcohol from the crude product by vacuum fractional distillation. The total yield of the reaction was $59.5 \%$.

The reagent $\mathrm{CIP}\left(\mathrm{NMe}_{2}\right)_{2}$ was used to convert the tetraamine to $p$ methylbenzyl azaphosphatrane chloride. It was prepared by reaction of 1 eq of $\mathrm{PCl}_{3}$ with 2 eq of $\mathrm{P}\left(\mathrm{NMe}_{2}\right)_{3}$ in acetonitrile. The advantage of using $\mathrm{CIP}\left(\mathrm{NMe}_{2}\right)_{2}$ is that the byproduct, $\mathrm{Me}_{2} \mathrm{NH}$, is a gas and can simply be released from the reaction mixture through a gas outlet. An overall yield of $60.2 \%$ was obtained.

The crude $p$-methylbenzyl azaphosphatrane chloride is an extremely viscous oil that is soluble in $\mathrm{CHCl}_{3}$, THF, and insoluble in ether and hexanes. Attempts to purify the compound by recrystallization lead to the product oiling out. On standing for approximately two months, the isolated oil began to slowly crystallize. However, the crystals could not be separated from the adhering noncrystalline oil. Pure crystals were obtained by a slow diffusion of ether into a THF solution of the product. The product did initially oil out, but after two months standing in the dark, crystals formed on the flask walls at the level of the ether layer. A crystallographic analysis was conducted and is discussed in Section 2.2d.

The $p$-methylbenzyl proazaphosphatrane synthesis (via deprotonation of $p$-methylbenzyl azaphosphatrane chloride using potassium $t$-butoxide) had to be conducted using Schlenk techniques as the product is air sensitive. The compound was stored under nitrogen in a drybox. The small amount of product was collected as a film, which did not allow an accurate determination of the final mass and percent yield. 


\section{3d. Crystal Structure of the p-Methylbenzyl Azaphosphatrane Chloride}

Salt

A crystallographic structure of the $p$-methylbenzyl azaphosphatrane chloride salt was obtained. The compound crystallizes in the monoclinic space group $\mathrm{P} 2{ }_{1} / \mathrm{c}$. An ORTEP drawing is shown in Figure 23. Table 1 presents crystal data and structure refinement parameters. Table 2 shows selected bond lengths and bond angles.

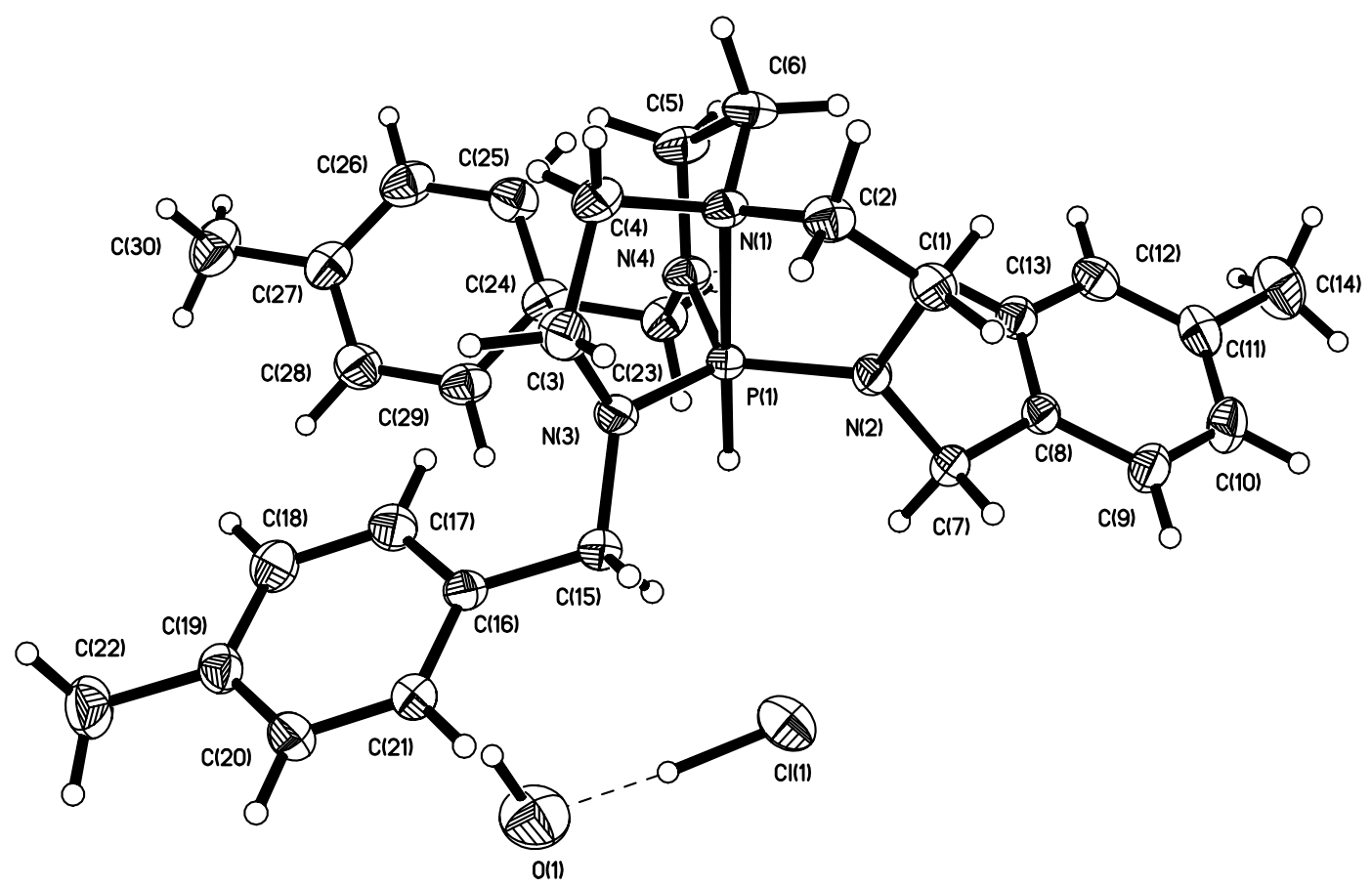

Figure 23. ORTEP drawing of the $p$-methylbenzyl azaphosphatrane chloride salt. Thermal ellipsoids are scaled to $30 \%$ probability. 
Table 1. Crystal data and structure refinement for $\left[\mathrm{HPN}\left(\mathrm{CH}_{2} \mathrm{CH}_{2} \mathrm{NCH}_{2} \mathrm{C}_{6} \mathrm{H}_{4} \mathrm{Me}\right)_{3}\right] \mathrm{Cl} \cdot \mathrm{H}_{2} \mathrm{O}$.

\begin{tabular}{ll}
\hline Empirical formula & $\mathrm{C}_{30} \mathrm{H}_{42} \mathrm{CIN}{ }_{4} \mathrm{OP}$ \\
Formula weight & 541.1 \\
Temperature & $223(2) \mathrm{K}$ \\
Wavelength & 0.71073 angstroms \\
Crystal system & monoclinic \\
Space group & $\mathrm{P} 2{ }_{1} / \mathrm{c}$ \\
Unit cell dimensions & $\mathrm{a}=9.760(3) \quad$ alpha $=90$ degrees \\
$\quad$ (angstroms) & $\mathrm{b}=10.420(3)$ beta $=91.501$ degrees \\
& $\mathrm{C}=27.906(7)$ gamma $=90$ degrees \\
Density (calculated) & $1.267 \mathrm{~g} / \mathrm{cm}^{3}$ \\
Crystal size & $0.22 \times 0.25 \times 0.42 \mathrm{~mm}$ \\
Reflections collected & 19719 \\
Refinement method & Full-matrix least-squares
\end{tabular}


Table 2. Selected interatomic distances $[\AA]$ and bond angles $\left[{ }^{\circ}\right]$ for [HPN $\left(\mathrm{CH}_{2} \mathrm{CH}_{2} \mathrm{NCH}_{2} \mathrm{C}_{6} \mathrm{H}_{4} \mathrm{Me}\right)_{3} \mathrm{Cl} \cdot \mathrm{H}_{2} \mathrm{O}$.

\begin{tabular}{rrlr}
\hline $\mathrm{P}(1)-\mathrm{N}(1)$ & $1.9578(19)$ & $\mathrm{N}(2)-\mathrm{P}(1)-\mathrm{N}(4)$ & $120.75(11)$ \\
$\mathrm{P}(1)-\mathrm{N}(2)$ & $1.649(2)$ & $\mathrm{N}(2)-\mathrm{P}(1)-\mathrm{N}(3)$ & $118.70(12)$ \\
$\mathrm{P}(1)-\mathrm{N}(3)$ & $1.664(2)$ & $\mathrm{N}(4)-\mathrm{P}(1)-\mathrm{N}(3)$ & $118.99(12)$ \\
$\mathrm{P}(1)-\mathrm{N}(4)$ & $1.654(2)$ & $\mathrm{N}(2)-\mathrm{P}(1)-\mathrm{N}(1)$ & $85.77(9)$ \\
$\mathrm{P}(1)-\mathrm{H}(1)$ & 1.293 & $\mathrm{~N}(4)-\mathrm{P}(1)-\mathrm{N}(1)$ & $85.87(9)$ \\
$\mathrm{N}(1)-\mathrm{C}(2)$ & $1.474(3)$ & $\mathrm{N}(3)-\mathrm{P}(1)-\mathrm{N}(1)$ & $85.89(9)$ \\
$\mathrm{N}(1)-\mathrm{C}(4)$ & $1.468(3)$ & $\mathrm{C}(4)-\mathrm{N}(1)-\mathrm{C}(2)$ & $113.0(2)$ \\
$\mathrm{N}(1)-\mathrm{C}(6)$ & $1.479(3)$ & $\mathrm{C}(4)-\mathrm{N}(1)-\mathrm{C}(6)$ & $113.2(2)$ \\
$\mathrm{N}(2)-\mathrm{C}(1)$ & $1.448(3)$ & $\mathrm{C}(2)-\mathrm{N}(1)-\mathrm{C}(6)$ & $111.51(19)$ \\
$\mathrm{N}(3)-\mathrm{C}(3)$ & $1.449(3)$ & $\mathrm{C}(4)-\mathrm{N}(1)-\mathrm{P}(1)$ & $105.76(14)$ \\
$\mathrm{N}(4)-\mathrm{C}(5)$ & $1.459(3)$ & $\mathrm{C}(2)-\mathrm{N}(1)-\mathrm{P}(1)$ & $106.78(14)$ \\
$\mathrm{C}(1)-\mathrm{C}(2)$ & $1.449(4)$ & $\mathrm{C}(6)-\mathrm{N}(1)-\mathrm{P}(1)$ & $105.97(15)$ \\
$\mathrm{C}(3)-\mathrm{C}(4)$ & $1.501(4)$ & $\mathrm{C}(7)-\mathrm{N}(2)-\mathrm{C}(1)$ & $115.59(19)$ \\
$\mathrm{C}(5)-\mathrm{C}(6)$ & $1.506(4)$ & $\mathrm{C}(7)-\mathrm{N}(2)-\mathrm{P}(1)$ & $123.11(16)$ \\
& & $\mathrm{C}(1)-\mathrm{N}(2)-\mathrm{P}(1)$ & $121.25(16)$ \\
& & $\mathrm{C}(3)-\mathrm{N}(3)-\mathrm{C}(15)$ & $114.7(2)$ \\
& & $\mathrm{C}(3)-\mathrm{N}(3)-\mathrm{P}(1)$ & $120.34(17)$ \\
& & $\mathrm{C}(15)-\mathrm{N}(3)-\mathrm{P}(1)$ & $120.68(17)$ \\
& & $\mathrm{C}(5)-\mathrm{N}(4)-\mathrm{C}(23)$ & $114.9(2)$ \\
& & $\mathrm{C}(5)-\mathrm{N}(4)-\mathrm{P}(1)$ & $121.33(17)$ \\
& & $\mathrm{C}(23)-\mathrm{N}(4)-\mathrm{P}(1)$ & $123.66(17)$ \\
& & $\mathrm{N}(2)-\mathrm{C}(1)-\mathrm{C}(2)$ & $106.7(2)$ \\
& & $\mathrm{N}(1)-\mathrm{C}(2)-\mathrm{C}(1)$ & $105.6(2)$ \\
& & $\mathrm{N}(3)-\mathrm{C}(3)-\mathrm{C}(4)$ & $105.8(2)$ \\
& & $\mathrm{N}(4)-\mathrm{C}(4)-\mathrm{C}(3)-\mathrm{C}(6)$ & $105.5(2)$ \\
& & & $105.9(2)$ \\
& & & $106.0(2)$
\end{tabular}


The crystal structure of the $p$-methylbenzyl azaphosphatrane chloride salt shows the transannular bond between phosphorus and the bridgehead nitrogen. The phosphorus is nearly trigonal bipyramidal. The $\mathrm{N}_{\text {eq }}-\mathrm{P}-\mathrm{N}_{\text {bridgehead }}$ angles are slightly less than $90^{\circ}$. The three $\mathrm{N}_{\text {eq }}-\mathrm{P}-\mathrm{N}_{\text {eq }}$ angles are $120.75^{\circ}, 118.70^{\circ}$, and $118.99^{\circ}$. The molecule has a radius of approximately $7.5 \AA$ from the carbon atom of the $p$-methyl group to the phosphorus atom. An oxygen atom is hydrogen bonded to the chlorine indicating the presence of water in the solvent.

\subsection{Experimental}

Solvents were HPLC grade or better. Pyrrole was distilled when discolored. THF and ether used to deprotonate the $p$-methylbenzyl phosphatrane were taken from a special drying system used to ensure elimination of water. 4-phenylpyridine, 3-phenylpyridine, quinoline, triisopropylphosphite, triphenylphosphine, tris(2,4-di-t-butylphenyl)phosphite, and the methyl and isobutyl proazaphosphatranes were purchased and used as received. Quinoline was purified by simple distillation before use due to discoloration.

Nuclear magnetic resonance spectra were determined on either a JEOLGSX-270 MHz or a Varian $600 \mathrm{MHz}$ NMR spectrometer.

$\mathrm{H}_{2}$ (TTP). $\mathrm{H}_{2}$ TTP was prepared in a $23 \%$ yield from pyrrole and $p$ tolualdehyde by the Adler method. ${ }^{6}{ }^{1} \mathrm{H}$ NMR was consistent with literature values.

Zn(T2,6FBzOPP). $10 \mathrm{mg}(4.6 \mu \mathrm{mol}) \mathrm{H}_{2}$ (T2,6FBzOPP), $50 \mathrm{mg}(0.23$ $\mathrm{mmol})$ zinc acetate, and $50 \mathrm{mg}(0.37 \mathrm{mmol})$ sodium acetate were added to 20 $\mathrm{mL}$ acetic acid in a $50 \mathrm{~mL}$ round-bottomed flask. The reaction was refluxed for $20 \mathrm{~h}$, then $100 \mathrm{~mL} \mathrm{H}_{2} \mathrm{O}$ was added to the reaction mixture. The mixture was stirred for $5 \mathrm{~min}$, then allowed to settle for $30 \mathrm{~min}$. The precipitate was collected on a frit, washed with a sodium bicarbonate solution, washed with $\mathrm{H}_{2} \mathrm{O}$, then allowed to air dry. Purity was confirmed by TLC, $9.3 \mathrm{mg}(90 \%)$ was recovered. ${ }^{1} \mathrm{H}$ NMR $\left(\mathrm{CDCl}_{3}\right): \delta 4.77\left(\mathrm{~s}, 12 \mathrm{H},-\mathrm{OCH}_{2}-\right), 7.12(\mathrm{~d}, \mathrm{~J}=8.3 \mathrm{~Hz}, 8 \mathrm{H}, \mathrm{m}-\mathrm{H}), 7.71(\mathrm{~m}$, 
$4 \mathrm{H}, p-\mathrm{H}), 8.58(\mathrm{~s}, 8 \mathrm{H}, \beta-\mathrm{H}) . \quad \mathrm{UV}$-vis (toluene): $\varepsilon_{\max }, \mathrm{nm},,\left(10^{-3} \mathrm{M}\right), \mathrm{cm}^{-1} \mathrm{M}^{-1} ; 400.6$ (sh), 27.5; 424.0, 242.8; 550.0, 14.6 .

Zn(T2,6MeOPP). $20 \mathrm{mg}(0.023 \mathrm{mmol}) \mathrm{H}_{2}(\mathrm{~T} 2,6 \mathrm{MeOPP}), 100 \mathrm{mg}$ zinc acetate $(0.46 \mathrm{mmol})$, and $100 \mathrm{mg}(0.74 \mathrm{mmol})$ sodium acetate were added to 30 $\mathrm{mL}$ acetic acid in a $100 \mathrm{~mL}$ round-bottomed flask. The reaction was refluxed for $20 \mathrm{~h}$, then $100 \mathrm{~mL} \mathrm{H}_{2} \mathrm{O}$ was added to the reaction mixture. The mixture was stirred for $5 \mathrm{~min}$, then allowed to settle for $30 \mathrm{~min}$. The precipitate was collected on a frit, washed with a saturated sodium bicarbonate solution, washed with $\mathrm{H}_{2} \mathrm{O}$, then allowed to air dry. The total yield was $19.4 \mathrm{mg}(91 \%) .{ }^{1} \mathrm{H}$ NMR $\left(\mathrm{CDCl}_{3}\right): \delta$ $3.50\left(\mathrm{~s}, 24 \mathrm{H},-\mathrm{OCH}_{3}\right), 6.98(\mathrm{~d}, \mathrm{~J}=8.6 \mathrm{~Hz}, 8 \mathrm{H}, m-\mathrm{H}), 7.68(\mathrm{~m}, 4 \mathrm{H}, p-\mathrm{H}), 8.76(\mathrm{~s}$, $8 \mathrm{H}, \beta-\mathrm{H})$. UV-vis (toluene): $\varepsilon_{\max }, \mathrm{nm},,\left(10^{-3} \mathrm{M}\right), \mathrm{cm}^{-1} \mathrm{M}^{-1} ; 404.5,39.1 ; 423.0$, 254.9; 550.0, 24.5.

$\mathrm{N}\left(\mathrm{CH}_{2} \mathrm{CH}_{2} \mathrm{NHCH}_{2} \mathrm{C}_{6} \mathrm{H}_{4} \mathrm{CH}_{3}\right)_{3} .15 .0 \mathrm{~mL}(0.100 \mathrm{~mol})$ tris(2-aminoethyl)amine was placed in a $500 \mathrm{~mL}$ round-bottomed flask. The flask was cooled in an ice bath. $47.2 \mathrm{~mL}(0.400 \mathrm{~mol})$ of $p$-tolualdehyde in an $80 \%(\mathrm{v} / \mathrm{v})$ solution with $t$-butyl alcohol was added over a period of $20 \mathrm{~min}$. The reaction mixture was allowed to slowly come to room temperature and stirred for $1 \mathrm{~h} .100 \mathrm{~mL}$ of methanol was added. The reaction mixture was cooled to $\sim 5^{\circ} \mathrm{C}$ and $11.1 \mathrm{~g}$ sodium borohydride was added over a period of $1 \mathrm{~h}$. The reaction was quenched by adding $60 \mathrm{~mL}$ of $50 \%(\mathrm{w} / \mathrm{w})$ aqueous $\mathrm{NaOH}$. Addition of $100 \mathrm{~mL}$ distilled water dissolved solids present. The desired product was extracted with hexanes $(4 \times 100 \mathrm{~mL})$. The extracts were combined and treated with $50 \mathrm{~mL}$ of 1 $\mathrm{M} \mathrm{Nal}$ (aq). After separating the hexane layer, the Nal fraction was extracted with hexanes $(3 \times 50 \mathrm{~mL})$. All hexanes extracts were combined, dried over potassium carbonate, filtered, and all volatiles were removed under reduced pressure. Purification was achieved by subliming out the white crystalline solid p-methylbenzyl alcohol in a Kugelrohr distillation apparatus, thus leaving the triamine in the original distillation bulb. Total recovery was $29.9 \mathrm{~mL}(59.2 \%)$. ${ }^{1} \mathrm{H}$ $\operatorname{NMR}\left(\mathrm{CDCl}_{3}\right): \delta 1.86(\mathrm{~s}, \mathrm{br}, 3 \mathrm{H}, \mathrm{N}-\mathrm{H}), 2.32\left(\mathrm{~s}, 9 \mathrm{H},-\mathrm{CH}_{3}\right), 2.55(\mathrm{t}, \mathrm{J}=10.8 \mathrm{~Hz}, 6 \mathrm{H}$, 
$\left.-\mathrm{CH}_{2} \mathrm{CH}_{2-}\right), 2.64\left(\mathrm{t}, \mathrm{J}=10.6 \mathrm{~Hz}, 6 \mathrm{H},-\mathrm{CH}_{2} \mathrm{CH}_{2-}\right), 3.68\left(\mathrm{~s}, 6 \mathrm{H},-\mathrm{CH}_{2}-\right), 7.06-7.22$ (overlapping region, $12 \mathrm{H}, o-$ and $m-\mathrm{H}$ ).

[HPN $\left.\left(\mathrm{CH}_{2} \mathrm{CH}_{2} \mathrm{NHCH}_{2} \mathrm{C}_{6} \mathrm{H}_{4} \mathrm{CH}_{3}\right)_{3}\right] \mathrm{Cl}$. This synthesis must be conducted in a dry, oxygen-free atmosphere. Schlenk glassware was used. The reaction flask must be equipped with a gas outlet for release of the byproduct $\mathrm{Me}_{2} \mathrm{NH}$. $\mathrm{CIP}\left(\mathrm{NMe}_{2}\right)_{2}$ was prepared in situ by dissolving $6.35 \mathrm{~mL}(35.0 \mathrm{mmol}) \mathrm{P}\left(\mathrm{NMe}_{2}\right)_{3}$ in $125 \mathrm{~mL}$ acetonitrile, then slowly adding $1.53 \mathrm{~mL}(17.5 \mathrm{mmol}) \mathrm{PCl}_{3}$. A solution of $22.94 \mathrm{~g}(50 \mathrm{mmol}) \mathrm{N}\left(\mathrm{CH}_{2} \mathrm{CH}_{2} \mathrm{NHCH}_{2} \mathrm{C}_{6} \mathrm{H}_{4} \mathrm{CH}_{3}\right)_{3}$ in $50 \mathrm{~mL}$ acetonitrile was then slowly added to the $\mathrm{CIP}\left(\mathrm{NMe}_{2}\right)_{2}$ solution. The reaction mixture was stirred for 2 $\mathrm{h}, 100 \mathrm{~mL}$ ether was added, and the reaction was stirred for an additional $2 \mathrm{~h}$ period. Volatiles were removed under reduced pressure, then the residue was partitioned between acetonitrile and hexanes (100 $\mathrm{mL}$ each). The hexane contains unreacted $\mathrm{N}\left(\mathrm{CH}_{2} \mathrm{CH}_{2} \mathrm{NHCH}_{2} \mathrm{C}_{6} \mathrm{H}_{4} \mathrm{CH}_{3}\right)_{3}$, the acetonitrile contains the azaphosphatrane. The acetonitrile layer was taken to dryness under reduced pressure, leaving a yellow residue. The residue is not particularly air sensitive. The residue was dissolved in a minimal amount of THF, and then ether was added until the precipitation of a yellow sludge was complete. The flask was placed in a freezer for $24 \mathrm{~h}$. The solvents were decanted and the product was dried under reduced pressure, leaving a yellow oil. The total amount of solid collected was $47.16 \mathrm{~g}(60.2 \%)$. Crystallization of a small amount of the product was achieved via dissolving in THF, covering with an equal amount of ether, and placing in a dark cabinet for $\sim 2$ months. ${ }^{1} \mathrm{H}$ NMR $\left(\mathrm{CDCl}_{3}\right)$ : $\delta 2.33\left(\mathrm{~s}, 9 \mathrm{H},-\mathrm{CH}_{3}\right)$, $3.06\left(\mathrm{~m}, 6 \mathrm{H},-\mathrm{CH}_{2} \mathrm{CH}_{2}-\right), 3.55\left(\mathrm{~m}, 6 \mathrm{H},-\mathrm{CH}_{2} \mathrm{CH}_{2^{-}}\right), 4.09\left(\mathrm{~d}, \mathrm{~J}=16.8,6 \mathrm{H},-\mathrm{CH}_{2}-\right)$, $4.85(\mathrm{~s}, 1 \mathrm{H}, \mathrm{P}-\mathrm{H}), 7.01-7.16(\mathrm{~m}, 12 \mathrm{H}, \mathrm{o}-$ and $m-\mathrm{H}) .{ }^{13} \mathrm{C}$ NMR $\left({ }^{1} \mathrm{H}\right.$ decoupled) $\left(\mathrm{CDCl}_{3}\right): \delta 21.50$ (d, J=11.4 Hz, - $\left.\mathrm{CH}_{3}\right), 40.11$ (d, J=22.8 Hz, $\left.-\mathrm{CH}_{2} \mathrm{CH}_{2}-\right), 47.97$ (d, $\mathrm{J}=27.6 \mathrm{~Hz},-\mathrm{CH}_{2} \mathrm{CH}_{2^{-}}$), 51.23 (d, J=64.2 Hz, $-\mathrm{CH}_{2}$ ), 128.31 (s, aryl-C), 128.68 (s, aryl-C), 130.04 (s, aryl-C), 136.46 (d, J=25.2 Hz, aryl-C). ${ }^{31}$ P NMR: $\delta$-10.87, small impurity peaks were noted at $-20.07,-6.51$, and $4.42 \mathrm{ppm}$.

$\mathrm{PN}\left(\mathrm{CH}_{2} \mathrm{CH}_{2} \mathrm{NHCH}_{2} \mathrm{C}_{6} \mathrm{H}_{4} \mathrm{CH}_{3}\right)_{3}$. This synthesis must be conducted in a dry, oxygen-free atmosphere. A solution of $1.50 \mathrm{~g} \mathrm{(2.87 \textrm {mmol } )}$ 
[HPN $\left.\left(\mathrm{CH}_{2} \mathrm{CH}_{2} \mathrm{NHCH}_{2} \mathrm{C}_{6} \mathrm{H}_{4} \mathrm{CH}_{3}\right)_{3}\right] \mathrm{Cl}$ and $0.643 \mathrm{~g}(5.74 \mathrm{mmol}) t-\mathrm{BuOK}$ in $50 \mathrm{~mL}$ THF in a $500 \mathrm{~mL}$ Schlenk flask was degassed for 2 periods of 10 min each, then placed under $\mathrm{N}_{2}$ gas. The solution was stirred for $2 \mathrm{~h}$, and then the THF was removed under reduced pressure. $150 \mathrm{~mL}$ hexane was added, followed by a $1 \mathrm{~h}$ stirring period. The mixture was allowed to settle, then the liquid was transferred via canula through a Schlenk frit into another $500 \mathrm{~mL}$ Schlenk frit. Another 100 $\mathrm{mL}$ hexane was added to the original reaction flask, stirred for 30 minutes, then transferred to the collection flask. The hexane was removed under reduced pressure, leaving a white waxy film. The flask containing the product was transferred to a nitrogen drybox. The mass by difference of the product was $\sim 1$ g. No accurate final mass was obtained due to the difficulties associated with drybox use (vibrations, air currents). ${ }^{1} \mathrm{H}$ NMR $\left(\mathrm{C}_{6} \mathrm{D}_{6}\right): \delta 2.17\left(\mathrm{~s}, 9 \mathrm{H},-\mathrm{CH}_{3}\right), 2.64$ $\left(\mathrm{m}, 6 \mathrm{H},-\mathrm{CH}_{2} \mathrm{CH}_{2^{-}}\right), 2.77\left(\mathrm{~m}, 6 \mathrm{H},-\mathrm{CH}_{2} \mathrm{CH}_{2^{-}}\right), 4.23$ (d, J=9.0 Hz, 6H, $\left.-\mathrm{CH}_{2^{-}}\right), 7.08$ $(\mathrm{d}, \mathrm{J}=7.8 \mathrm{~Hz}, 6 \mathrm{H}, \mathrm{o}-\mathrm{H}), 7.38(\mathrm{~d}, \mathrm{~J}=7.8 \mathrm{~Hz}, 6 \mathrm{H}, m-\mathrm{H}) .{ }^{13} \mathrm{C}$ NMR $\left({ }^{1} \mathrm{H}\right.$ decoupled) $\left(\mathrm{C}_{6} \mathrm{D}_{6}\right): \delta 21.48\left(\mathrm{~s},-\mathrm{CH}_{3}\right), 45.91$ (d, J=25.2 Hz, $\left.-\mathrm{CH}_{2} \mathrm{CH}_{2}-\right), 51.62\left(\mathrm{~s},-\mathrm{CH}_{2} \mathrm{CH}_{2}\right.$ ), 53.81 (s, - $\mathrm{CH}_{2}$ ), 128.31 (s, aryl-C), 128.68 (s, aryl-C), 128.91 (s, aryl-C), 129.70 (s, aryl-C). ${ }^{31} \mathrm{P}$ NMR $\left(\mathrm{C}_{6} \mathrm{D}_{6}\right): \delta 128.17$, plus 3 impurity peaks $(-12.04,24.06$, and 30.78 ) which were small relative to peak at 128.17 . 


\section{References from Chapter 2}

1. Adler, A. D.; Longo, F. R.; Shergalis, W. "Mechanistic Investigation of Porphyrin Synthesis. I. Preliminary Studies on ms-Tetraphenylporphyrin." J. Am. Chem. Soc., 1964, 86, 3145-3149.

2. Barnett, G. H.; Hudson, M. F.; Smith, K. M. "meso-Tetraphenylporphyrin Purification." Tetrahedron., 1973, 2887-2888.

3. Kadish, K. M.; Smith, K. M.; Guilard, R. The Porphyrin Handbook. Volume 1: Synthesis and Organic Chemistry. San Diego: Academic Press, 2000.

4. Lindsey, J. S.; Schreiman, I. C.; Hsu, H. C.; Kearney, P. C.; Marguerettaz, A. M. "Rothemund and Adler-Longo Reactions Revisited: Synthesis of Tetraphenylporphyrins Under Equilibrium Conditions." J. Org. Chem., 1987, 52, 827-836.

5. Lindsey, J. S.; MacCrum, K. A.; Tyhonas, J. S.; Chuang, Y. "Investigation of a Synthesis of meso-Porphyrins Employing High Concentration Conditions and an Electron Transport Chain for Aerobic Oxidation." J. Org. Chem., 1994, 59, 579-583.

6. Adler, A. D.; Longo, F. R.; Finarelli, J. D.; Goldmacher, J.; Assour, J.; Korsakoff, L. "A Simplified Synthesis for meso-Tetraphenylporphyrin." J. Org. Chem., 1967, 32, 476.

7. Lindsey, J. S.; Wagner, R. W. "Investigation of the Synthesis of OrthoSubstituted Tetraphenylporphyrins." J. Org. Chem., 1989, 54, 828-836.

8. Bonnett, R.; Dimsdale, M. J. "The meso-Reactivity of Porphyrins and Related Compounds. Part V. The meso-Oxidation of Metalloporphyrins." J. Chem. Soc., Perkin Trans. 1, 1972, 2540-2548.

9. Kisanga, P. B.; Verkade, J. G. "Synthesis of New Proazaphosphatranes and Their Application in Organic Synthesis." Tetrahedron Lett., 2001, 57, 467-475.

10. Tang, J.; Thyagarajan, M.; Verkade, J. G. "Selective and Efficient Synthesis of Perhydro-1,3,5-triazine-2,4,6-triones and Carbodiimides from 
Isocyanates Using $\mathrm{ZP}\left(\mathrm{MeNCH}_{2} \mathrm{CH}_{2}\right)_{3} \mathrm{~N}$ Catalysts." J. Org. Chem., 1994, 59, 4931-4938.

11. Tang, J.; Laramay, M. A. H.; Young, V.; Ringrose, S.; Jacobson, R. A.; Verkade, J. G. "Stepwise Transannular Bond Formation Between the Bridgehead Atoms in $\mathrm{ZP}\left(\mathrm{MeNCH}_{2} \mathrm{CH}_{2}\right)_{3} \mathrm{~N}$ Systems." J. Am. Chem. Soc., 1992, 114, 3129-3131.

12. Lensink, C.; Xi, S. K.; Daniels, L. M.; Verkade, J. G. "The Unusually Robust P-H Bond in the Novel Cation $\mathrm{HP}\left(\mathrm{NMeCH}_{2} \mathrm{CH}_{2}\right)_{3} \mathrm{~N}^{+}$." J. $\mathrm{Am}$. Chem. Soc., 1989, 111, 3478-3479.

13. Tang, J.; Dopke, J.; Verkade, J. G. "Synthesis of New Exceedingly Strong Non-Ionic Bases: $\mathrm{RN}=\mathrm{P}\left(\mathrm{MeNCH}_{2} \mathrm{CH}_{2}\right)_{3} \mathrm{~N}$." J. Am. Chem. Soc., 1993, 115, 5015-5020.

14. Liu, X. -D.; Verkade, J. G. "Unusual Phosphoryl Donor Properties of $\mathrm{O}=\mathrm{P}\left(\mathrm{MeNCH}_{2} \mathrm{CH}_{2}\right)_{3} \mathrm{~N}$." Inorg. Chem., 1998, 37, 5189-5197.

15. Laramay, M. A. H.; Verkade, J. G.; 'The 'Anamalous' Basicity of $\mathrm{P}\left(\mathrm{NHCH}_{2} \mathrm{CH}_{2}\right)_{3} \mathrm{~N}$ Relative to $\mathrm{P}\left(\mathrm{NMeCH}_{2} \mathrm{CH}_{2}\right)_{3} \mathrm{~N}$ and $\mathrm{P}\left(\mathrm{NBzCH}_{2} \mathrm{CH}_{2}\right)_{3} \mathrm{~N}$ : A Chemical Consequence of Orbital Charge Balance?" J. Am. Chem. Soc., 1990, 112, 9421-9422.

16. Xi, S. K.; Schmidt, H.; Lensick, C.; Kim, S.; Wintergrass, D.; Daniels, L. M.; Jacobson, R. A.; Verkade, J. G. "Bridgehead-Bridgehead Communication in Untransannulated $\mathrm{ZP}\left(\mathrm{ECH}_{2} \mathrm{CH}_{2}\right)_{3} \mathrm{~N}$ Systems." Inorg. Chem., 1990, 29, 2214-2220. 


\section{CHAPTER 3: LIGAND BINDING EXPERIMENTS}

\subsection{Background}

The determination of equilibrium constants and thermodynamic data for the coordination of axial ligands to metalloporphyrins has received great interest due to the role of metalloporphyrins in biological systems. ${ }^{1}$ Several techniques can be employed in studying these systems, but one of the most convenient and commonly used is spectrophotometric measurements. ${ }^{2}$ These measurements can be evaluated graphically or by computer techniques that use least-squared methods of obtaining equilibrium constants. Also, the experiments can be carried out at just one wavelength and temperature, or up to several wavelengths and temperatures.

Graphical evaluation of equilibrium systems is the traditional method of deducing equilibrium constants, but suffers from many limitations. ${ }^{2}$ First, graphical methods rarely yield reliable estimates of errors. Second, it is difficult to decide if a good fit of the data to the proposed functional relationship exists. Third, frequently extrapolation from the given data to a point is used to evaluate parameters of the system. Therefore, the precision of evaluated parameters may be compromised. And finally, graphical methods tend to be more time consuming than computer-based methods. The greater availability of computing power reduces the need for graphical methods, many of which were developed before widespread availability of computers, by providing a simpler way to solve complicated sets of equations.

Computer programs using least-squares methods of obtaining equilibrium constants were developed to supplement graphical methods for calculating stability constants. Error values of equilibrium constants obtained by computerbased methods are better defined than those of constants obtained graphically. ${ }^{3}$ Also, cumulative errors of successive graphical extrapolation methods are avoided. $^{3}$ 
Equilibrium constants obtained from graphical methods at a single wavelength and temperature were reported for coordination of various pyridine derivatives to zinc(II) tetraphenylporphyrin. ${ }^{4}$ The measurements were taken in benzene at $25.0 \pm 0.1^{\circ} \mathrm{C}$ and ranged from a $\log K$ of 1.82 for coordination of 2,4,6-trimethylpyridine to ZnTTP to a log $K$ of 5.05 for coordination of piperidine to ZnTTP. Error values given in this study were $\pm 0.1 \mathrm{log}$ units or less.

Thermodynamic values were reported for coordination of various substituted pyridines to iron(II) porphyrins in benzene using computer-based least-squared methods at several single wavelengths. ${ }^{5}$ In all cases studied, the iron(II) porphyrins added two ligands to form their respective complexes. ${ }^{5}$ Enthalpy and entropy values were determined from a van't Hoff plot of $\log K$ vs. $1 / T$ in the temperature range of $18-40^{\circ} \mathrm{C}$. Enthalpy values $\left(\mathrm{kcal} \mathrm{mol}^{-1}\right)$ found in this study ranged from -16.1 for coordination of 4-aminopyridine to protoporphyriniron(II) dimethylester up to +7.5 for coordination of 4-cyanopyridine to diacetyldeuteroporphyriniron(II) dimethyl ester. Entropy values (cal mol${ }^{-1} \mathrm{deg}^{-}$ ${ }^{1}$ ) reported ranged from -28 for coordination of 4-aminopyridine to protoporphyriniron(II) dimethylester up to +42 for coordination of 4-carboxy- $n$ butylpyridine to diacetyldeuteroporphyriniron(II) dimethyl ester. ${ }^{a}$ The study was conducted to obtain bond energies of iron(II) porphyrin-pyridine complexes, but the compensatory effect of $\Delta S$ on $\Delta H$ and $\Delta G$ made free-energy data an unsatisfactory guide to the bond energies of the studied complexes. ${ }^{5}$

Stolzenberg and Summers used multiple temperatures and wavelengths to obtain axial ligation equilibrium constants and thermodynamic data for coordination of a series of pyridines and piperidine to cobalt(II) and zinc(II) porphyrin complexes of octaethylporphyrin, $t$-octaethylchlorin, and the tct-and tttisomers of octaethylisobacteriochlorin in $1993 .{ }^{6}$ The results showed that equilibrium constants increase with increasing saturation of the cobalt(II) and

a Positive entropy values for these systems is chemically unreasonable 
zinc(II) macrocycles. The method used for obtaining equilibrium constants in that project were also used in our present project.

\subsection{Experimental}

Zinc porphyrin concentrations were held constant at $10^{-5} \mathrm{M}$ for all experiments. Ligand concentrations were varied as needed to cover a sizable amount of the saturation curve of each equilibrium, i.e. to range from a small conversion to a near complete conversion to ligand-bound zinc porphyrin as compared to unbound zinc porphyrin. This approach sometimes required that experiments be repeated with different ligand concentrations if the results of the experiment showed that the first set of solutions did not give a reasonable range of percent conversion to ligand-bound zinc porphyrin.

A typical experiment began with the preparation of samples. All solutions were prepared using syringe techniques and volumetric glassware. First, a $10^{-4} \mathrm{M}$ solution of the appropriate zinc porphyrin was prepared in toluene. Dilution with toluene of $10.00 \mathrm{~mL}$ of this solution to $100.0 \mathrm{~mL}$ afforded stock solution $A\left(10^{-5} \mathrm{M}\right)$. A second solution, $B$, was prepared by adding enough of the ligand to prepare the highest desired concentration of axial base to $1.00 \mathrm{~mL}$ of the $10^{-4} \mathrm{M}$ solution of the zinc complex and then diluting to $10.00 \mathrm{~mL}$ with toluene (giving $10^{-5} \mathrm{M}$ zinc porphyrin plus the desired concentration of ligand). Finally, five more solutions were prepared by serial dilution of solution $B$. These five solutions were diluted to their final volume with stock solution A. Therefore, all samples contained $10^{-5} \mathrm{M}$ zinc porphyrin plus known concentrations of axial base. Overall, a sample set had eight cuvettes: one with zinc porphyrin only $\left(10^{-5} \mathrm{M}\right)$, six with zinc porphyrin $\left(10^{-5} \mathrm{M}\right)$ plus ligand (varying concentrations), and a toluene blank.

Absorption spectra were recorded on a Perkin-Elmer Lambda 6 doublebeam spectrophotometer. The temperature was controlled to $\pm 0.1^{\circ} \mathrm{C}$ with a Haake F3-CH circulating bath. The bath water was circulated through a waterjacketed single-position cuvette holder in the spectrophotometer sample compartment and an insulated six-position aluminum block, which was used to 
store and equilibrate the temperature of the cuvettes prior to recording spectra. The sample temperature was measured at the cuvette holder.

Spectra were collected for all samples at six temperatures ranging from 5 to $70^{\circ} \mathrm{C}$. Due to increased humidity levels in the building, condensation became a problem for samples at $5^{\circ} \mathrm{C}$. Collection at this temperature was not always possible. The majority of ligand binding experiments had spectral data recorded at temperatures near $15,25,35,50$, and $70^{\circ} \mathrm{C}$. Collection of spectra began at $25^{\circ} \mathrm{C}$. Once the system became steady at one temperature, this temperature was recorded to one decimal place. Spectra of all seven samples were obtained from $350-700 \mathrm{~nm}$. Collection of spectra continued at elevated temperatures of 35,50 , and $70^{\circ} \mathrm{C}$. The samples were then cooled and spectra were obtained at 5,15 , and $25^{\circ} \mathrm{C}$. The initial and final sets of spectra measured near $25^{\circ} \mathrm{C}$ were always compared to check for sample decomposition.

Triaryl and triallylphosphites presented problems during the course of their respective binding experiments. At high concentrations, an intense visible peak would appear near $650 \mathrm{~nm}$. The absorption of this peak increased as time passed, at higher temperatures, or in the presence of room light. The underlying chemical process was found to be irreversible. Equilibrium constants and thermodynamic data were not collected for the coordination of triphenylphosphite to zinc porphyrins due to this chemistry. Data for the coordination of triisopropylphosphite to zinc porphyrins was successfully obtained over a smaller temperature range $\left(25-50^{\circ} \mathrm{C}\right)$.

The program SQUAD was used to calculate equilibrium constants and their associated errors. SQUAD calculates the best values of equilibrium constants for an equilibrium model by using a nonlinear least-squares approach to simultaneously fit absorption data at multiple wavelengths for solutions of varying ligand concentration. Data points were selected in increments of $5 \mathrm{~nm}$ between 530-630 nm and were read from the spectra files and formatted as a SQUAD input file by an OBEY program. The input files (example SQUAD input and output files are displayed in Appendices D and E) were edited to include 
complex and ligand concentration values prior to running SQUAD. SQUAD permits extinction coefficients to be entered as constants or to be calculated by the program. The SQUAD program was permitted to calculate the extinction coefficients, as the consistency of the calculated spectra provided an additional check of the quality of each experiment.

The wavelength range (530-630 $\mathrm{nm}$ ) used to calculate equilibrium constants and subsequent thermodynamic values includes the visible bands of zinc porphyrins. An equilibrium mixture of zinc porphyrin and axial ligand exhibits visible bands that are red-shifted relative to a solution of only zinc porphyrin. A set of selected spectra at a specific temperature shows that the shift of the visible band decreases with decreasing concentration of the axial ligand (Figure 26).

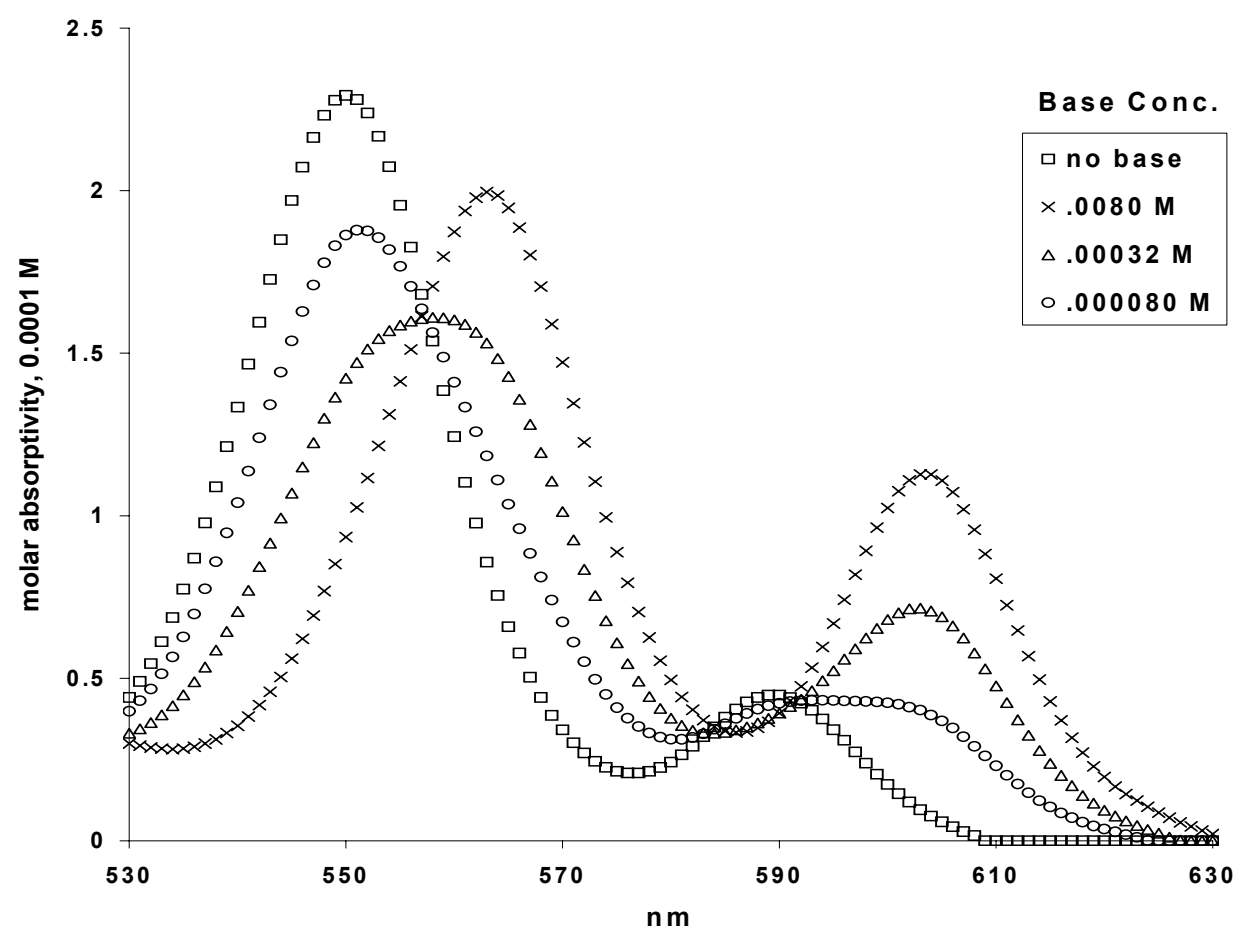

Figure 24. Example of a set of selected spectra from one temperature in a ligand binding experiment. This is $10^{-5} \mathrm{M} Z \mathrm{nTTP}$ plus varying concentrations of 3-phenylpyridine at $25.0^{\circ} \mathrm{C}$. The legend displays concentrations of 3-phenylpyridine. The visible band shift decreases with decreasing ligand concentration. Appendices $B$ and $C$ display more examples of spectra obtained during this project. 
The change in composition in solution that is represented by the spectra in Figure 24 can be observed by the naked eye as well. A $10^{-5} \mathrm{M}$ zinc porphyrin solution is pink in color. When a binding ligand is introduced, the solution's color changes to green. As the binding ligand concentration is decreased by serial dilution, the green becomes less intense and sometimes returns to pink.

After all spectra were taken, the SQUAD program was used to calculate $\mathrm{K}_{\mathrm{eq}}$ at each temperature. Data were fitted to one stoichiometric model (equation 9 ), as zinc porphyrin complexes in solution only coordinate one axial ligand ${ }^{7}$ :

$$
Z n(P)+L=Z n(P) L
$$

The $K_{\text {eq }}$ values were then fit to a van't Hoff plot of log $K$ vs. 1/T (refer to Figure 25), which allows entropy and enthalpy changes associated with the equilibrium to be obtained. The slope of the line corresponds to $\Delta H$ and the $x$-intercept corresponds to $\Delta S$. 


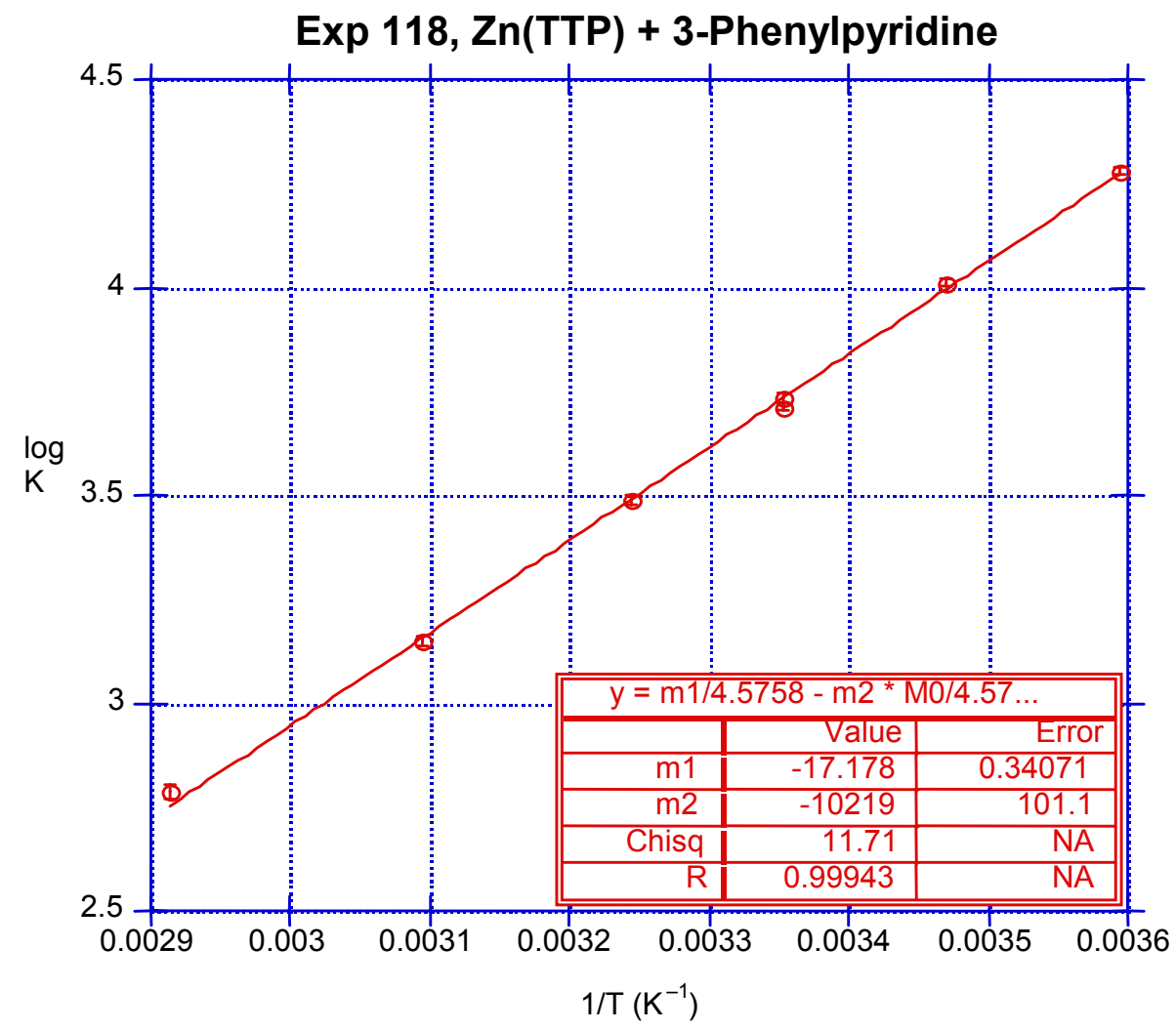

Figure 25. Plot of $\log K$ vs. 1/T for coordination of 3-phenylpyridine to ZnTTP. Error bars represent 1 standard deviation. $\mathrm{m} 1$ represents $\Delta S\left(\mathrm{cal} \mathrm{K}^{-1} \mathrm{~mol}^{-1}\right), \mathrm{m} 2$ represents $\Delta H\left(\mathrm{cal} \mathrm{mol}^{-1}\right)$. Appendix A displays examples of van't Hoff plots obtained from this project. 


\subsection{Results}

Table 3 shows equilibrium constants determined for the coordination of several axial bases to the four different zinc(II) porphyrins. Tables 4 and 5 show entropy and enthalpy values obtained from the van't Hoff plot for each equilibrium.

Table 3. Equilibrium Constants for Coordination of Bases by Zn(II) Porphyrin Complexes in Toluene.

\begin{tabular}{|c|c|c|c|c|}
\hline \multicolumn{5}{|c|}{$\log K$ at $25^{\circ} \mathrm{C}$} \\
\hline base & ZnTTP & ZnTBPMPP & $\mathrm{ZnT}(2,6 \mathrm{FBzOP}) \mathrm{P}$ & $\mathrm{ZnT}(2,6 \mathrm{MeOP}) \mathrm{P}$ \\
\hline 4-phenylpyridine & $3.861(19)^{\mathrm{a}}$ & $4.019(06)$ & 3.699 (18) & $2.518(20)$ \\
\hline 3-phenylpyridine & $3.736(10)$ & $3.822(09)$ & $3.678(22)$ & $2.656(32)$ \\
\hline quinoline & $2.402(38)$ & $2.462(15)$ & $2.481(24)$ & $1.239(21)$ \\
\hline 1,10-phenanthroline & $1.119(73)$ & $1.379(19)$ & no binding ${ }^{b}$ & no binding \\
\hline triphenylphosphine ${ }^{c}$ & $3.083(15)$ & $3.248(20)$ & no binding & no binding \\
\hline triisopropylphosphite & $1.269(01)$ & $1.345(07)$ & no binding & no binding \\
\hline $\begin{array}{l}\text { tris(2,4-di-t-butyl- } \\
\text { phenyl)phosphite }\end{array}$ & no binding & no binding & no binding & no binding \\
\hline isobutyIPN3 & $4.269(34)$ & $4.092(24)$ & not available & $2.105(28)$ \\
\hline methyIPN3 & $3.945(18)$ & $4.381(25)$ & not available & $2.863(36)$ \\
\hline p-methylbenzyIPN3 & $4.187(26)$ & $4.635(24)$ & not available & $3.041(17)$ \\
\hline
\end{tabular}

\footnotetext{
a Numbers in parentheses are estimated standard deviations in the least significant digit.

b "No binding" refers to no spectral difference between solutions which contain $\mathrm{ZnP}$ only and solutions which contain $\mathrm{ZnP}$ and L.

c Triphenylphosphine measurements were taken in cyclohexane due to solubility problems in toluene.
} 
Table 4. Enthalpy Data for Coordination of Bases by Zinc(II) Porphyrin Complexes Measured over the range $15-70^{\circ} \mathrm{C}$ in Toluene.

\begin{tabular}{|c|c|c|c|c|}
\hline \multicolumn{5}{|c|}{$\Delta H(\mathrm{kcal} / \mathrm{mol})$} \\
\hline base & ZnTTP & ZnTBPMPP & $\mathrm{ZnT}(2,6 \mathrm{FBzOP}) \mathrm{P}$ & $\mathrm{ZnT}(2,6 \mathrm{MeOP}) \mathrm{P}$ \\
\hline 4-phenylpyridine & $-10.98(0.20)^{a}$ & $-10.80(0.08)$ & $-6.00(0.17)$ & $-5.81(0.19)$ \\
\hline 3-phenylpyridine & $-10.22(0.10)$ & $-10.32(0.06)$ & $-6.23(0.18)$ & $-5.93(0.26)$ \\
\hline quinoline & $-9.05(0.35)$ & $-8.88(0.12)$ & $-6.66(0.19)$ & $-5.14(0.25)$ \\
\hline 1,10-phenanthroline & $-10.12(2.74)$ & $-11.17(0.69)$ & & \\
\hline triphenylphosphine ${ }^{b}$ & $-8.84(1.56)$ & $-8.17(2.36)$ & & \\
\hline triisopropylphosphite & $-3.27(0.15)$ & $-5.05(0.12)$ & & \\
\hline $\begin{array}{l}\text { tris(2,4-di-t-butyl- } \\
\text { phenyl)phosphite }\end{array}$ & & & & \\
\hline isobutyIPN3 & $-3.89(0.32)$ & $-3.61(0.29)$ & & $-7.65(0.34)$ \\
\hline methyIPN3 & $-7.14(0.27)$ & $-7.39(0.18)$ & & $-9.53(0.74)$ \\
\hline p-methylbenzyIPN3 & $-2.57(0.39)$ & $-4.71(0.39)$ & & $-8.51(0.31)$ \\
\hline
\end{tabular}

\footnotetext{
a Numbers in parentheses are errors of fit.

b Triphenylphosphine measurements were taken in cyclohexane due to solubility problems in toluene.
} 
Table 5. Entropy Data for Coordination of Bases by Zinc(II) Porphyrin Complexes Measured over the range $15-70^{\circ} \mathrm{C}$ in Toluene.

\begin{tabular}{lcccc}
\hline \multicolumn{5}{c}{$\Delta$ B (cal/K mol) } \\
\multicolumn{1}{c}{ Base } & ZnTTP & ZnTBPMPP & ZnT(2,6FBzOP)P & ZnT(2,6MeOP)P \\
\hline 4-phenylpyridine & $-19.2(0.7)^{\mathrm{a}}$ & $-17.8(0.3)$ & $-3.2(0.6)$ & $-7.9(0.6)$ \\
3-phenylpyridine & $-17.2(0.3)$ & $-17.1(0.2)$ & $-4.1(0.6)$ & $-7.7(0.8)$ \\
quinoline & $-19.4(1.2)$ & $-18.5(0.4)$ & $-11.0(0.6)$ & $-11.6(0.9)$ \\
1,10-phenanthroline & $-28.8(9.1)$ & $-31.2(2.3)$ & & \\
triphenylphosphine & $-15.5(0.5)$ & $-12.4(0.8)$ & \\
triisopropylphosphite & $-5.2(0.5)$ & $-10.8(0.4)$ & \\
tris(2,4-di-t-butyl- & & & \\
phenyl)phosphite & & & \\
isobutylPN3 & $6.5(1.0)$ & $6.6(0.9)$ & $-16.0(1.1)$ \\
methylPN3 & $-5.9(0.9)$ & $-4.7(0.6)$ & $-14.6(1.0)$ \\
\hline p-methylbenzylPN3 & $10.5(1.3)$ & $5.4(1.3)$ & \\
\hline
\end{tabular}

a Numbers in parentheses are errors of fit.

b Triphenylphosphine measurements were taken in cyclohexane due to solubility problems in toluene. 
Inspection of the data tables shows several interesting points. Log $K$ for the coordination of 4-phenylpyridine to zinc tetra(p-tolyl)porphyrin is 3.861. The corresponding value for zinc tetra(3,5-bis(biphenylmethoxy)phenyl)porphyrin and 4-phenylpyridine is slightly larger at 4.019. The log $K$ value for zinc tetra((2,6perfluorobenzoxy)phenyl)porphyrin and 4-phenylpyridine is 3.699 , slightly smaller than that of zinc tetra( $p$-tolyl)porphyrin and 4-phenylpyridine. Log $K$ for the coordination of 4-phenylpyridine to zinc tetra((2,6-dimethoxy)phenyl)porphyrin is much lower compared to the other zinc porphyrins at 2.518. Similar trends were found for 3-phenylpyridine and quinoline.

Coordination of 1,10-phenanthroline and triisopropylphosphite to zinc tetra( $p$-tolyl)porphyrin and zinc tetra(3,5-bis(biphenylmethoxy)phenyl)porphyrin yielded the lowest $\log K$ values (between $\sim 1.1$ to 1.4 ) found for these porphyrins. 1,10-phenanthroline and triisopropylphosphite showed no appreciable binding to either zinc tetra((2,6-perfluorobenzoxy)phenyl)porphyrin or zinc tetra((2,6dimethoxy)phenyl)porphyrin.

Triphenylphosphine coordinated to both zinc tetra(p-tolyl)porphyrin and zinc tetra(3,5-bis(biphenylmethoxy)phenyl)porphyrin in cyclohexane with log $K$ values of 3.083 and 3.248 , but did not bind to either zinc tetra((2,6-perfluorobenzoxy)phenyl)porphyrin or zinc tetra((2,6-dimethoxy)phenyl)porphyrin. In general, $\log K$ values are significantly larger in cyclohexane than in toluene. ${ }^{6}$ Tris(2,4-di-t-butyl-phenyl)phosphite showed no detectable binding to any of the four zinc porphyrins that were studied.

The series of proazaphosphatranes (R-PN3) yielded the highest overall $\log K$ values for coordination to zinc tetra( $p$-tolyl)porphyrin and zinc tetra(3,5bis(biphenylmethoxy)phenyl)porphyrin. These values ranged from 3.945 for the coordination of the methyl proazaphosphatrane to zinc tetra(p-tolyl)porphyrin up to 4.635 for the coordination of the $p$-methylbenzyl proazaphosphatrane to zinc tetra(3,5-bis(biphenylmethoxy)phenyl)porphyrin. Coordination of each proazaphosphatrane to zinc tetra((2,6-dimethoxy)phenyl)porphyrin gave log $K$ values that were lower (by $\sim 1.1$ to 2.0 log units) compared to the other 
porphyrins. Ligand binding experiments were not conducted for the coordination of any of the three proazaphosphatranes to zinc tetra((2,6-perfluorobenzoxy) phenyl)porphyrin due to a limited supply of the porphyrin.

All systems studied were found to be exothermic as enthalpy values given in Table 4 are all negative. The $\Delta H$ values $(\mathrm{kcal} / \mathrm{mol})$ ranged from -11.17 for the coordination of 1,10-phenanthroline to zinc tetra(3,5-bis(biphenylmethoxy) phenyl)porphyrin up to -3.27 for the coordination of triisopropylphosphite to zinc tetra( $p$-tolyl)porphyrin. Overall, the most negative $\Delta H$ values, ranging from -11.17 to -8.88 , resulted from the coordination of the planar ligands $4-$ phenylpyridine, 3-phenylpyridine, quinoline, and 1,10-phenanthroline to either zinc tetra( $p$-tolyl)porphyrin or zinc tetra(3,5-bis(biphenylmethoxy)phenyl) porphyrin. As for the series of proazaphosphatranes, the most negative $\Delta H$ values $(-9.53$ to -7.65$)$ were found for coordination to zinc tetra((2,6dimethoxy)phenyl)porphyrin. The least negative $\Delta H$ values, ranging from -2.57 to -4.71 , resulted from the coordination of the isobutyl and $p$-methylbenzyl proazaphosphatranes to either zinc tetra( $p$-tolyl)porphyrin or zinc tetra(3,5bis(biphenylmethoxy)phenyl)porphyrin. Coordination of triisopropylphosphite to zinc tetra( $p$-tolyl)porphyrin and zinc tetra(3,5-bis(biphenylmethoxy)phenyl) porphyrin also yielded lesser negative $\Delta H$ values of -3.27 and -5.05 respectively. These lesser negative values may be artifacts, see Section 3.4.

Entropy values generally followed the same trends as the enthalpy values. The greatest loss of entropy resulted from the coordination of the planar ligands to zinc tetra(p-tolyl)porphyrin and zinc tetra(3,5-bis(biphenylmethoxy)phenyl) porphyrin. The $\Delta S$ values (cal K${ }^{-1} \mathrm{~mol}^{-1}$ ) for these systems ranged from -31.2 to -17.1. Coordination of each proazaphosphatrane to zinc tetra((2,6-dimethoxy) phenyl)porphyrin also resulted in a large loss of entropy, ranging from -18.9 to -14.6, as compared to the other systems that were studied.

Small negative $\Delta S$ values were found for the coordination of 4phenylpyridine and 3-phenylpyridine to zinc tetra((2,6-perfluorobenzoxy)phenyl) porphyrin at -3.2 and -4.1 respectively. In contrast, positive entropy values were 
obtained from the coordination of the isobutyl and $p$-methylbenzyl proazaphosphatranes to both zinc tetra( $p$-tolyl)porphyrin and zinc tetra(3,5bis(biphenylmethoxy)phenyl)porphyrin. These positive values were highly unexpected and are further discussed later.

\subsection{Discussion}

The data obtained in this project provide evidence that groups at the meso-positions of a porphyrin can affect equilibria of bases coordinating to a zinc(II) porphyrin. The 2,6-methoxyphenyl groups show lower log $\mathrm{K}$ values with even planar bases that have no side bulk (4-phenylpyridine). Both tetra((2,6perfluorobenzoxy)phenyl) and tetra(2,6-methoxyphenyl) are large enough to hinder 1,10-phenanthroline and the cone-shaped triisopropylphosphite from binding to zinc. Low equilibrium constants associated with the coordination of 1,10-phenanthroline could be the result of a conformational change of the porphyrin macrocycle. If 1,10-phenanthroline forces the porphyrin plane to bend during coordination, one would expect the equilibrium constant associated with this process to be low. This would be especially important in 1,10phenanthroline's attempt to bind to zinc tetra((2,6-perfluorobenzoxy)phenyl) porphyrin and zinc tetra((2,6-dimethoxy)phenyl)porphyrin. Bending of the porphyrin plane would likely cause the meso-substituents to interact with each other on the side opposite the axial ligand. This lack of free space would effectively eliminate any chance of coordination by 1,10-phenanthroline to either zinc tetra((2,6-perfluorobenzoxy)phenyl)porphyrin or zinc tetra((2,6-dimethoxy) phenyl)porphyrin.

An unexpected result was the observation that 2,6-methoxyphenyl groups have a greater effect on the coordination of planar ligands to a zinc(II) porphyrin than (2,6-perfluorobenzoxy)phenyl groups. This is surprising in light of findings published by Stolzenberg and Cao (discussed in Section 1.3). In particular, the results showed that (2,6-perfluorobenzoxy)phenyl groups were bulky enough to stop alkyl exchange between $\mathrm{Co}(\mathrm{TTP}) \mathrm{CH}_{3}$ and $\mathrm{Co}(\mathrm{T} 2,6 \mathrm{FBzOPP})$, whereas 2,6- 
methoxyphenyl groups only slow alkyl exchange between two cobalt(II) porphyrins.

Examination of entropy values of 3- and 4-phenylpyridine in Table 5 and space-filling models (Figures 26 and 27) of both ortho-substituted meso-groups suggests a possible explanation of the observations of this project in contrast to Stolzenberg/Cao's findings of (2,6-perfluorobenzoxy)phenyl groups being more sterically demanding than (2,6-methoxy)phenyl groups with respect to alkyl exchange between metalloporphyrins. The 2,6-methoxy groups on the mesophenyl rings are small enough to rotate over the porphyrin plane in its four coordinate form (Figure 26). Therefore, coordination of an axial base to the zinc(II) center that causes loss of rotational degrees of freedom (Figure 27) would lead to a more negative entropy value for the axial ligand coordination process. The $\Delta S$ values are more negative for the coordination of 4phenylpyridine, 3-phenylpyridine, and quinoline to zinc tetra((2,6dimethoxy)phenyl)porphyrin than to zinc tetra((2,6-perfluorobenzoxy)phenyl) porphyrin (refer to Table 5). As shown by the space filling models in Figure 26, the four (2,6-perfluorobenzoxy)phenyl groups are large enough to block each other's rotation above the porphyrin plane, thus coordination of an axial base causes no additional loss of rotational freedom. 

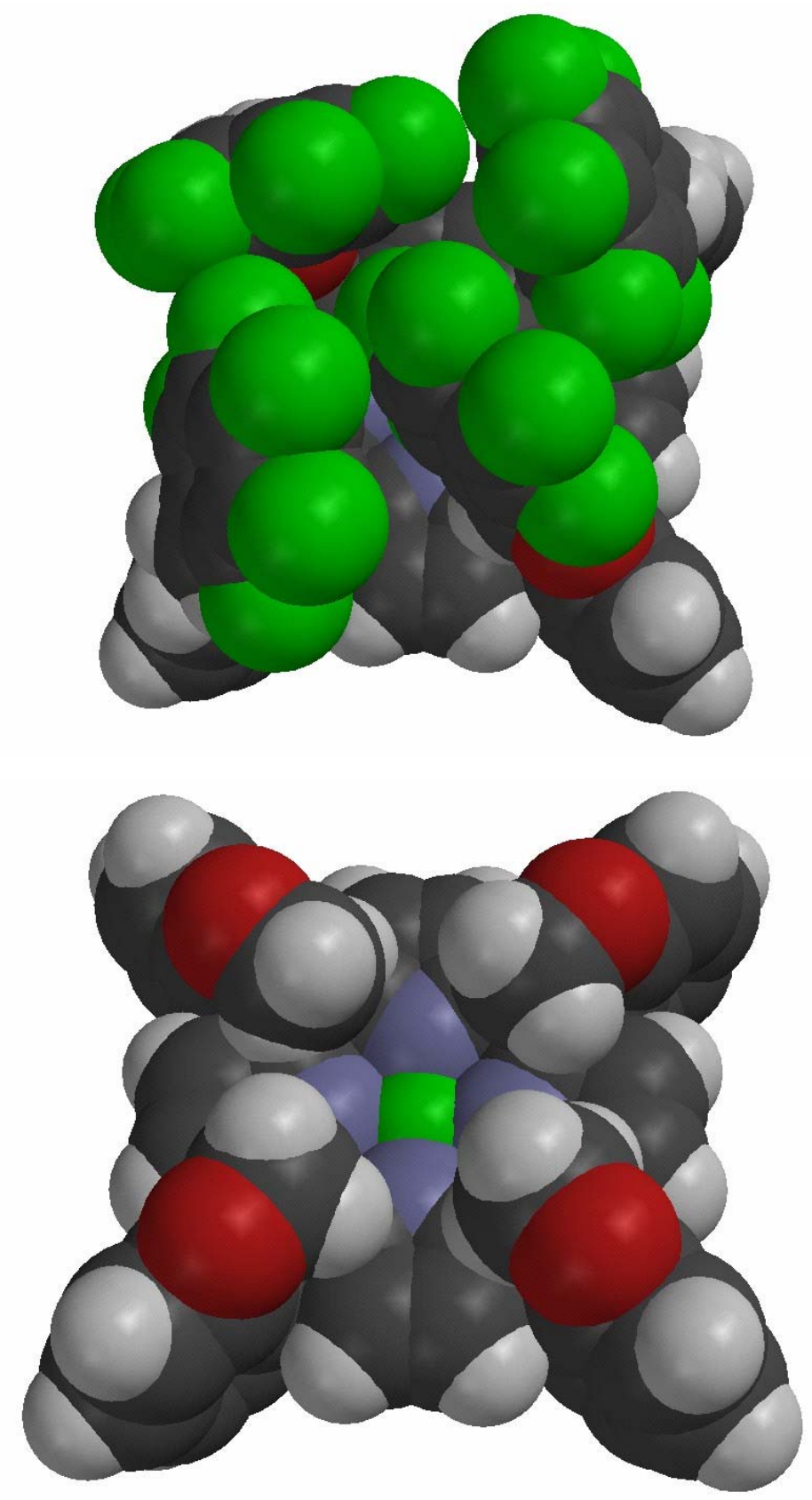

Figure 26. Space-filling models (top view) of zinc tetra((2,6-perfluorobenzoxy)phenyl)porphyrin (top) and zinc tetra((2,6-dimethoxy)phenyl)porphyrin (bottom). (2,6-perfluorobenzoxy)phenyl groups are large enough restrict each other's rotation above the zinc center. (2,6dimethoxy)phenyl groups are not large enough to hinder each other's rotation above the zinc center. 



Figure 27. Space-filling models of the coordination of 3-phenylpyridine to zinc tetra((2,6perfluorobenzoxy)phenyl)porphyrin (top) and zinc tetra((2,6-dimethoxy)phenyl)porphyrin (bottom). Coordination of an axial base would clearly hinder rotational freedom of the meso-substituents in each case. 
The Stolzenberg/Cao experiments also suggested that 3,5-bis(biphenylmethoxy)phenyl groups provided no more steric bulk than 3,5-methoxyphenyl groups with respect to alkyl exchange. Table 1 shows more evidence in favor of this observation. In every case, log $K$ values for zinc tetra(3,5-bis(biphenylmethoxy)phenyl) porphyrin are equal (within error) or higher than values found for axial coordination to zinc tetra( $p$-tolyl)porphyrin.

Another unexpected result from the project is the positive entropy values obtained from coordination of the isobutyl and $p$-methylbenzyl proazaphosphatranes to zinc tetra(p-tolyl)porphyrin and zinc tetra(3,5bis(biphenylmethoxy)phenyl)porphyrin. A possible explanation for these unexpected values is that the concentration range of base in the samples was too high and did not cover a wide area of the saturation curve, i.e. $\log K$ values are too large for these systems to be accurately determined by the method used. By not covering a large part of the saturation curve, the van't Hoff plot from these experiments may have been compromised. If the slope of the van't Hoff plot line (corresponding to the enthalpy of the process) was misjudged, then the intercept (corresponding to the entropy of the process) would be incorrect. This could lead to the positive entropy values observed for the coordination of the isobutyl and $p$ methylbenzyl proazaphosphatranes to zinc tetra(p-tolyl)porphyrin and zinc tetra(3,5-bis(biphenylmethoxy)phenyl)porphyrin. The situation was caused as a result of the ligand concentration approaching the zinc porphyrin concentration of the experiments in which positive entropy values were gathered. The lowest concentration of R-PN3 in these experiments was $8.0 \times 10^{-5} \mathrm{M}$. The concentration of base must be large enough to saturate the equilibrium (remember $[\mathrm{ZnP}]=1.0 \times 10^{-5} \mathrm{M}$ ). Perhaps, the actual $\log K$ values the coordination of the isobutyl and $p$-methylbenzyl proazaphosphatranes to zinc tetra( $p$-tolyl)porphyrin and zinc tetra(3,5-bis(biphenylmethoxy)phenyl)porphyrin are higher than reported here due to this situation, but can still be used for comparing with zinc tetra((2,6-dimethoxy)phenyl)porphyrin. We also think that 
the positive entropy values are an artifact of the method due to the more reasonable values obtained from the coordination of each proazaphosphatrane to zinc tetra((2,6-dimethoxy)phenyl)porphyrin. Smaller log $K$ values and thus more expected enthalpy and entropy terms were obtained from these experiments and we have no reason to believe that the corresponding systems with the other three zinc porphyrins should be chemically different

\subsection{Project Summary}

Axial ligand binding was used to probe the effective steric bulk of mesosubstituents on zinc porphyrin complexes. Equilibrium constants at $25.0^{\circ} \mathrm{C}$ and thermodynamic data measured over a range of $15-70^{\circ} \mathrm{C}$ were reported for the coordination of several bases to zinc porphyrins. The data reported for 3- and 4-phenylpyridine agree with studies of pyridine binding to zinc porphyrins conducted elsewhere. ${ }^{8}$ Data was also reported for triphenylphosphine, triisopropylphosphite, and a series of proazaphosphatranes. No comparisons to other data of this type were found in the literature.

One axial base used in the project was a previously unsynthesized proazaphosphatrane, where $\mathrm{R}=p$-methylbenzyl (refer to Figure 19). A crystal structure was obtained of the protonated chloride salt form of this compound. The crystallographic data were reported and discussed herein.

The ligand binding experiments provided evidence that meso-substituents on a zinc porphyrin can affect the ease of axial ligation of both planar and threedimensional ligands. Results show that 3,5-bis(biphenylmethoxy)phenyl groups are no more sterically demanding than $p$-tolyl groups on meso-substituted porphyrins, confirming observations found in previous experiments conducted by the Stolzenberg group that 3,5-bis(biphenylmethoxy)phenyl groups did not affect the rate of alkyl exchange between cobalt(II) porphyrins. The experiments also showed that due to a loss of rotational freedom during axial ligation, 2,6methoxyphenyl groups have a more pronounced effect on equilibrium constants than 2,6-(perfluorobenzoxy)phenyl groups. 


\section{References from Chapter 3}

1. Chapman, R. D.; Fleischer, E. B. "Direct Measurements of Electron SelfExchange Rates of Cobalt Porphyrins. 1. Outer-Sphere Exchange." J. Am. Chem. Soc., 1982, 104, 1575-1582.

2. Wentworth, W. E.; Hirsch, W.; Chen, E. "Rigorous Least-Squares Estimation of Molecular Complex Equilibria. I. Single Intermolecular Complex Utilizing Spectrophotometric Data." J. Phy. Chem., 1967, 71, 218-231.

3. Rossotti, F. J. C.; Rossotti, H. S.; Whewell, R. J. "The Use of Electronic Computing Techniques in the Calculation of Stability Constants." J. Inorg. Nucl. Chem., 1973, 33, 2051-2065.

4. Kirksey, C. H.; Hambright, P.; Storm, C. B. "Stability Constants and Proton Magnetic Resonance Studies of Zinc $\forall, \exists,(, *-T e t r a p h e n y \mid p o r p h i n$ and Substituted Pyridines." Inorg. Chem., 1969, 8, 2141-2144.

5. Cole, S. J.; Curthoys, G. C.; Magnusson, E. A. "Ligand Binding by Metalloporphyrins. I. Thermodynamic Functions of Porphyriniron(II)Pyridine Complexes." J. Am. Chem. Soc., 1970, 92, 2991-2996.

6. Summers, J. S.; Stolzenberg, A. M. "The Cis-Influence of Hydroporphyrin Macrocycles on the Axial Ligation Equilibria of Cobalt(II) and Zinc(II) Porphyrin Complexes." J. Am. Chem. Soc., 1993, 115, 10559-10567.

7. D'Souza, F.; Deviprasad, G. R.; Zandler, M. E. "Aggregation and Axial Ligand Exchange Behavior of Water-soluble Pyrrole- $\exists$ Brominated Porphyrins." J. Chem. Soc., Dalton Trans., 1997, 3699-3703.

8. Imai, H.; Kyuno, E. "Base Binding to Zinc Picket Fence Porphyrins. Attractive Intramolecular Interactions in Organic Solvents." Inorg. Chem., 1990, 29, 2416-2422. 


\section{APPENDIX A - SELECTED VAN'T HOFF PLOTS}

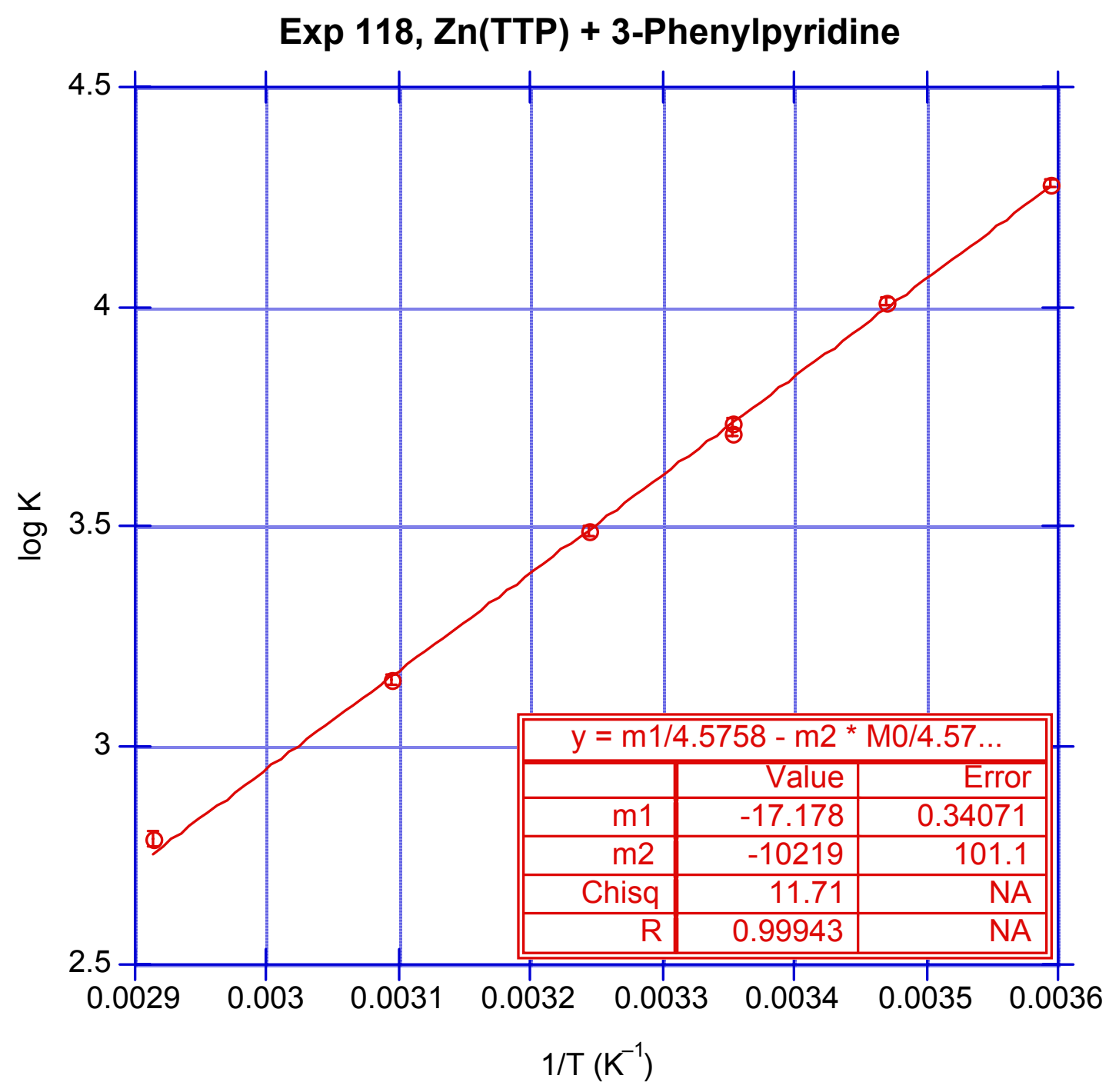




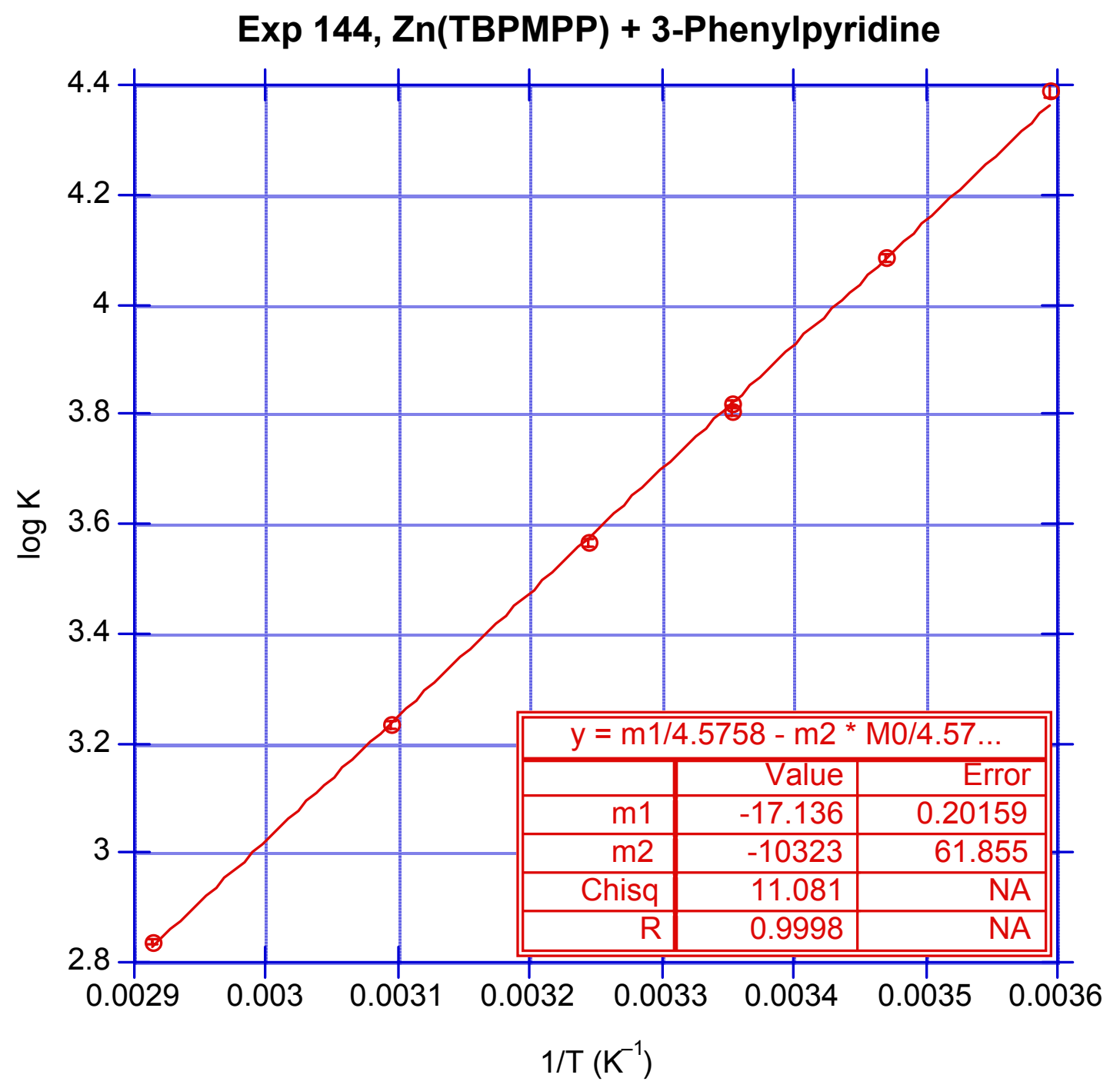


Exp 173, Zn(T26FBzOPP) + 3-Phenylpyridine

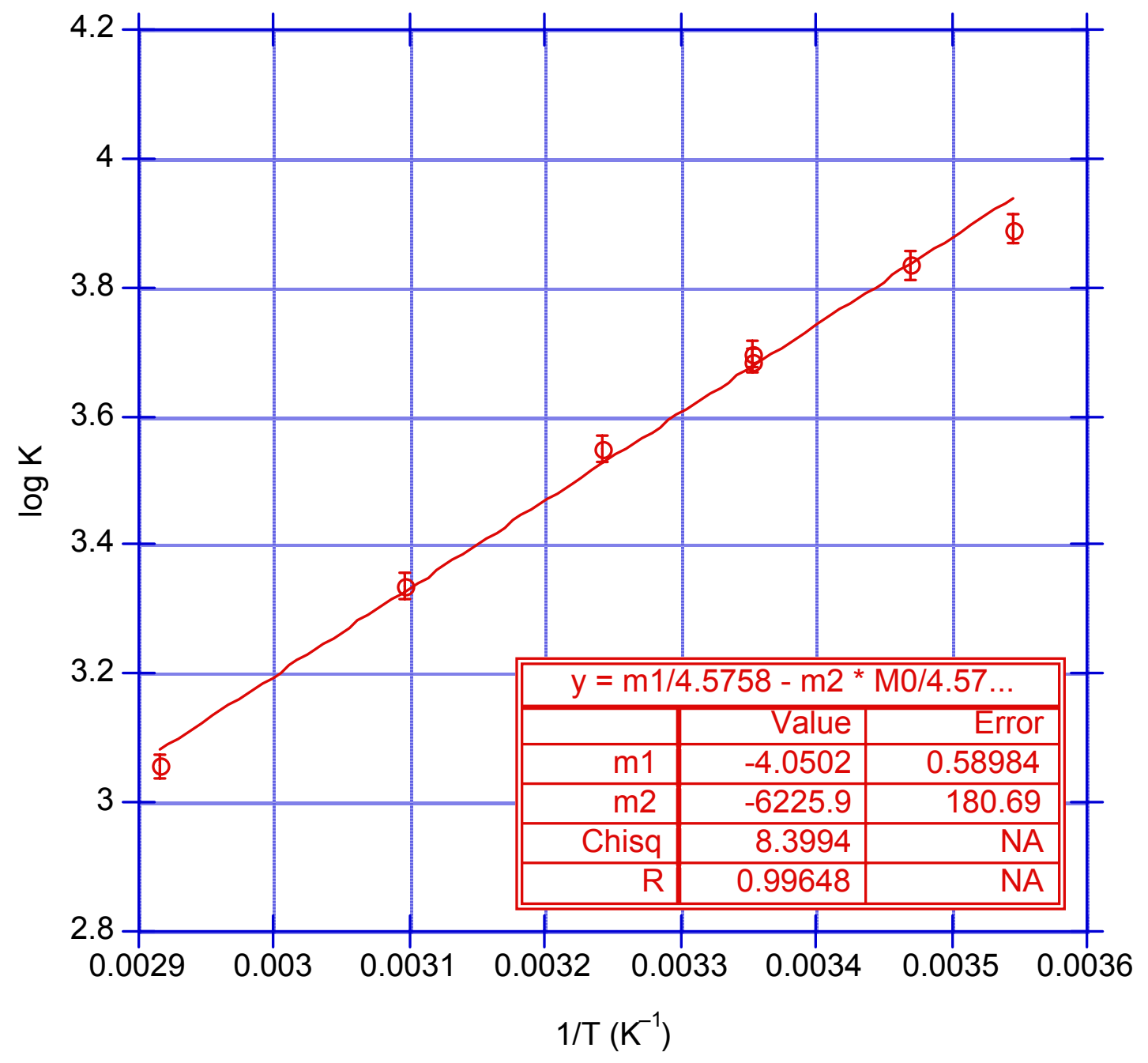




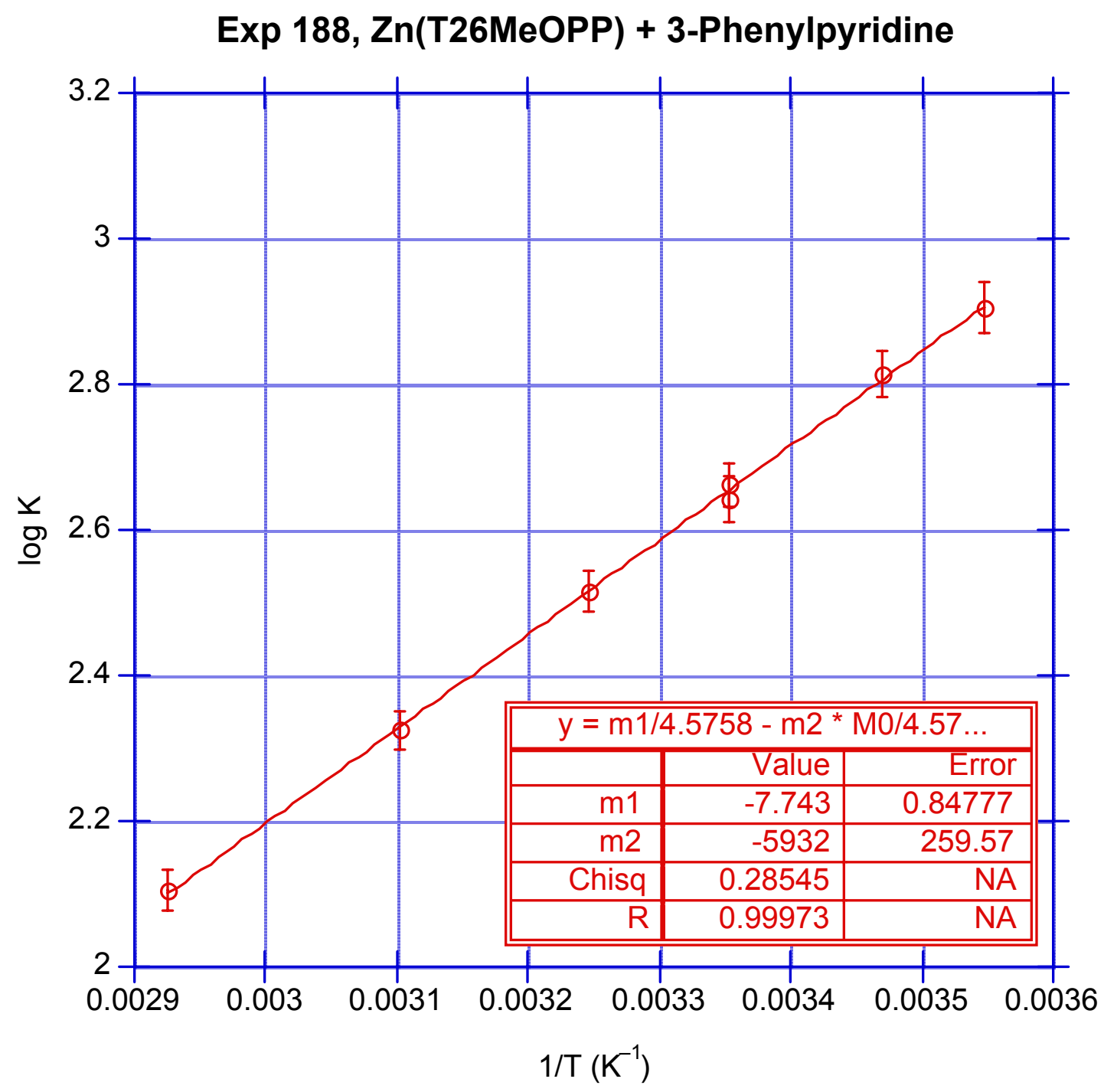




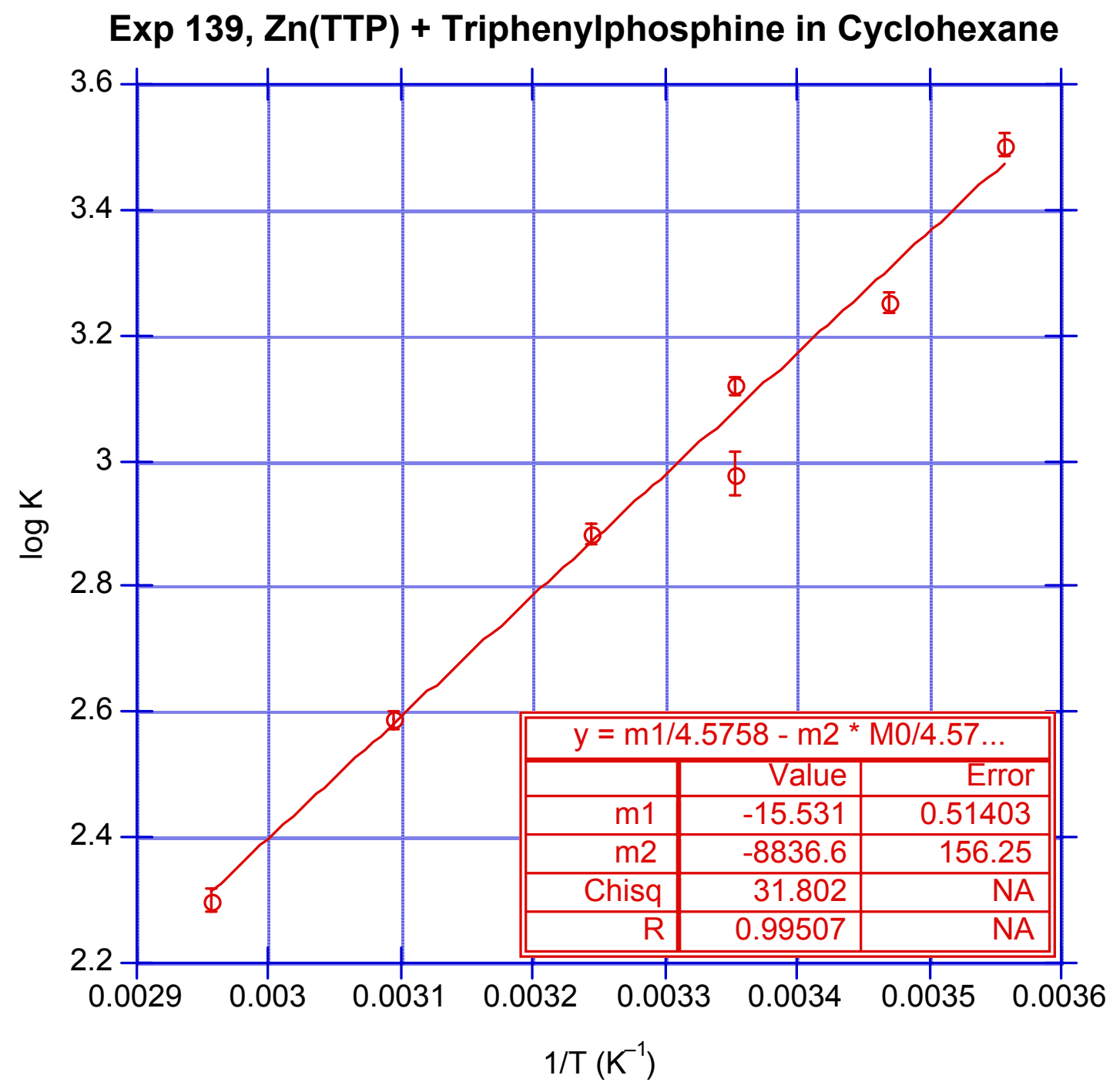

${ }^{* *}$ The final temperature point $\left(25.0^{\circ} \mathrm{C}\right)$ deviates below the other points. A discussion of this deviation can be found on page 36 . 


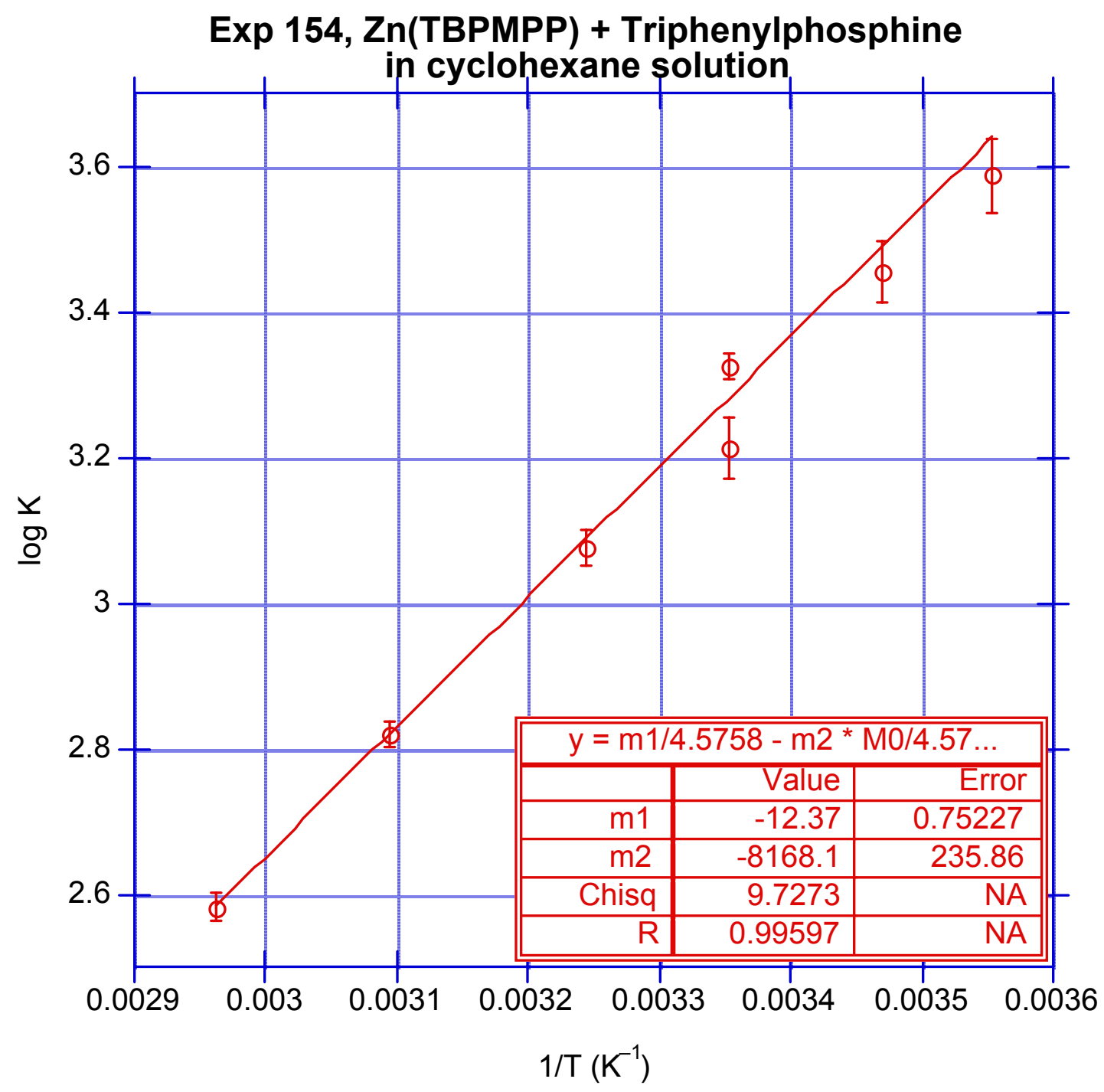

**The low temperature points have larger error bars due to solubility difficulties at temperatures below $35^{\circ} \mathrm{C}$. The final temperature point $\left(25.0^{\circ} \mathrm{C}\right)$ deviates below the other points. A discussion of this deviation can be found on page 36 . 


\section{Exp 241, Zn(TTP) + MethyIPN3}

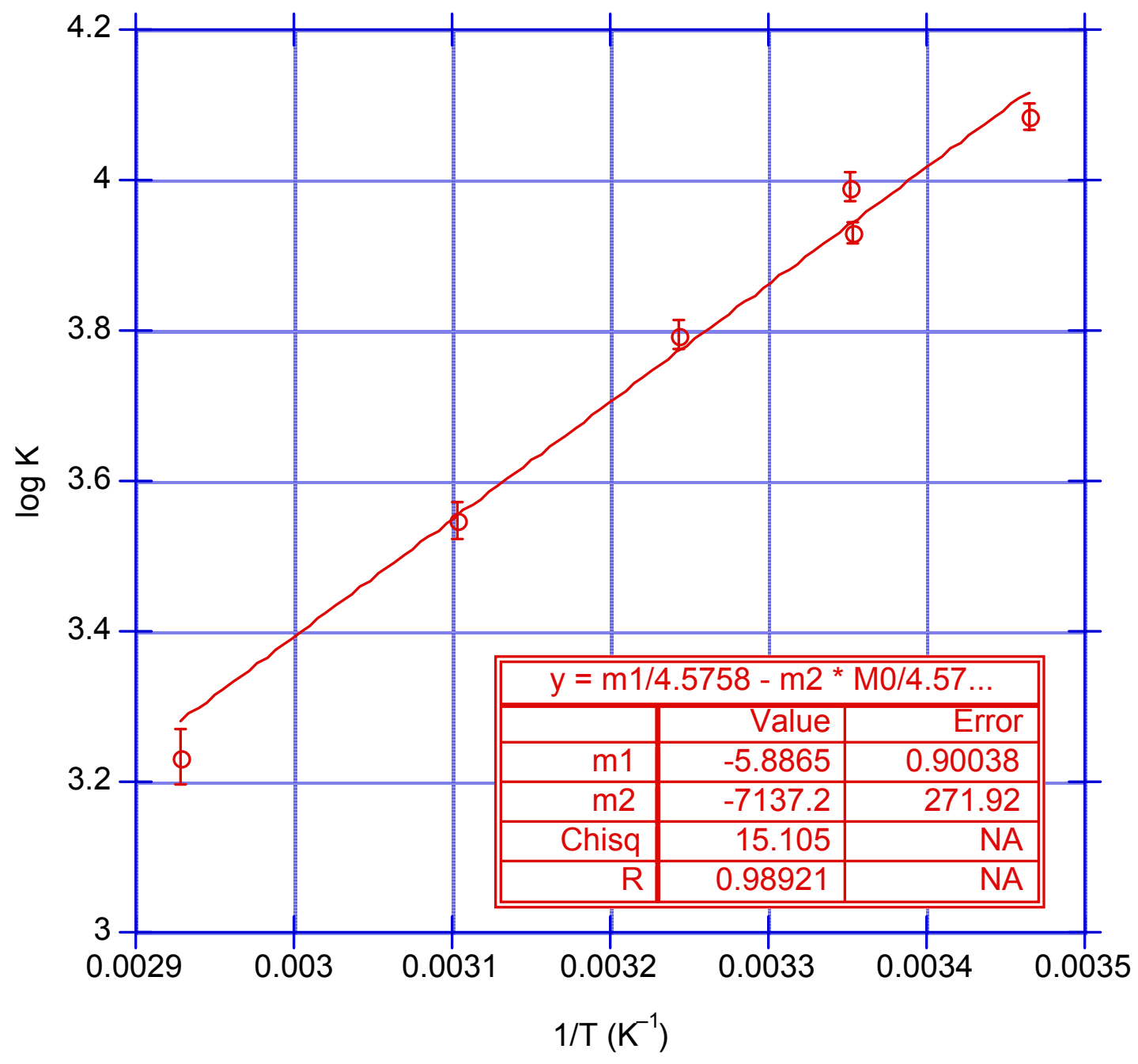

${ }^{* *}$ The final temperature point $\left(25.0^{\circ} \mathrm{C}\right)$ deviates below the other points. A discussion of this deviation can be found on page 36. The error bar at the highest temperature point is larger than expected. A discussion of this artifact can be found on page 49. 
Exp 243, Zn(T26MeOPP) + MePN3

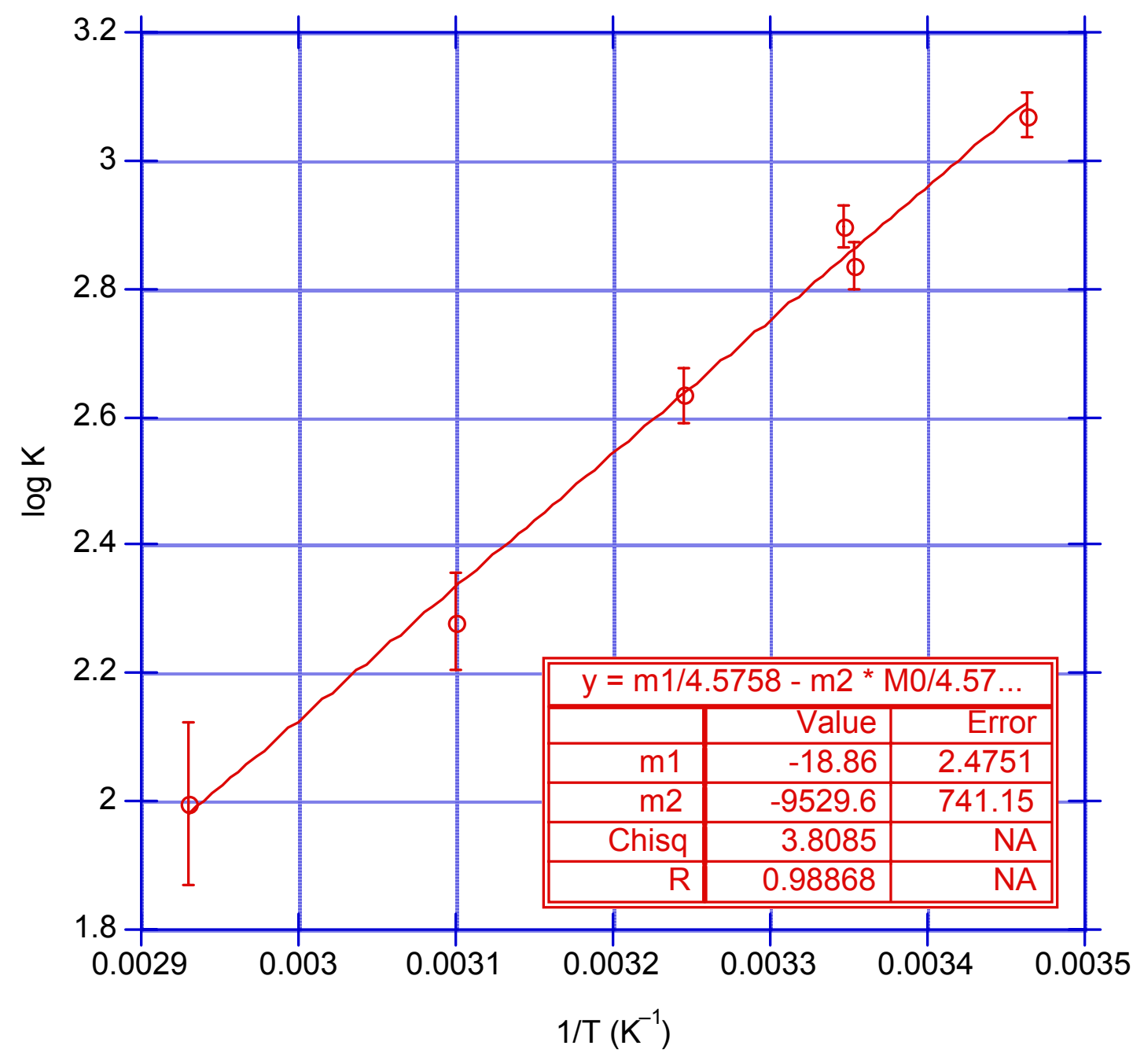

${ }^{* *}$ The final temperature point $\left(25.0^{\circ} \mathrm{C}\right)$ deviates below the other points. A discussion of this deviation can be found on page 36. The error bars at the highest temperature points are larger than expected. A discussion of this artifact can be found on page 49 . 
Exp 245, Zn(TBPMPP) + MePN3

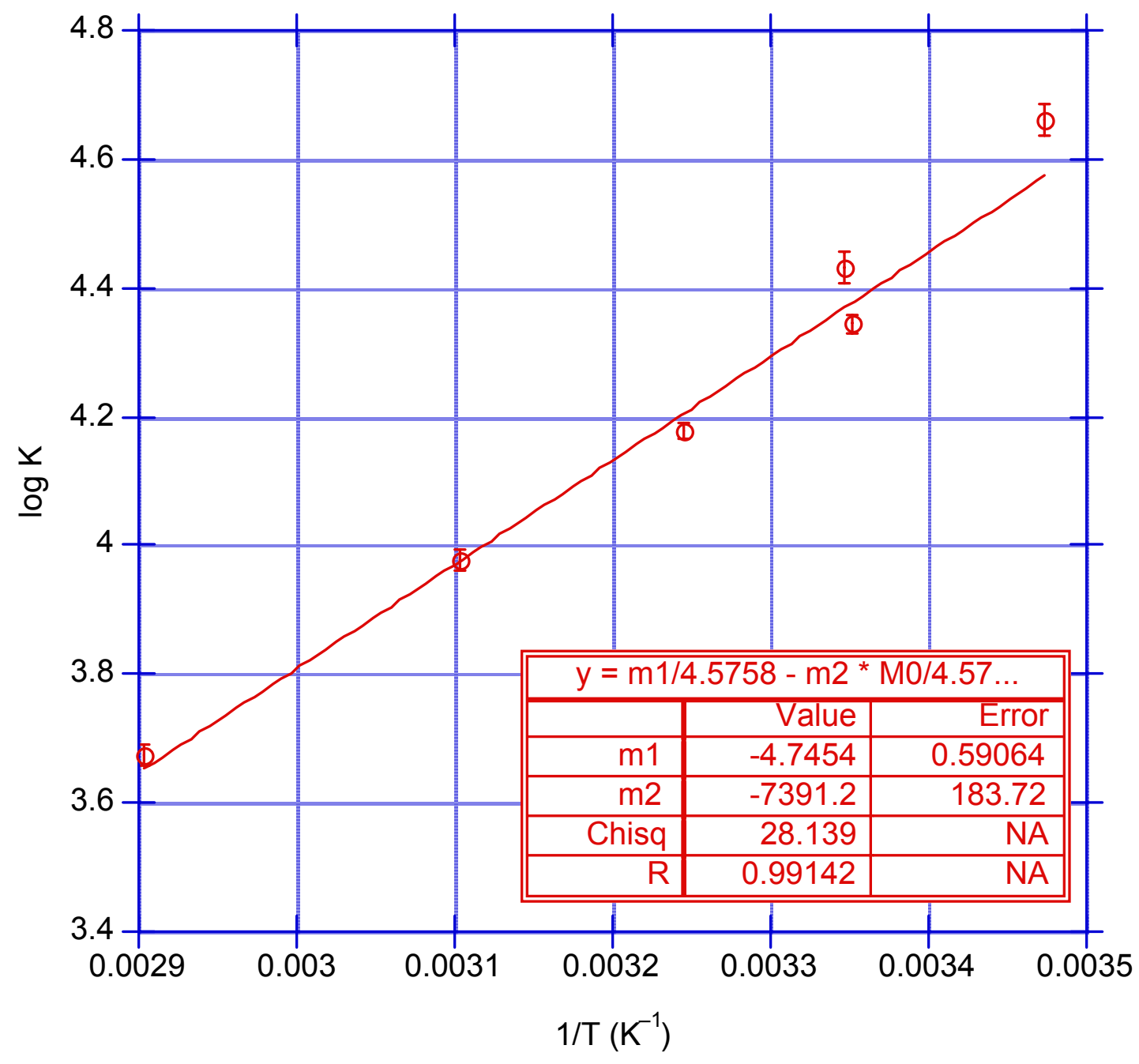

${ }^{* *}$ The final temperature point $\left(25.0^{\circ} \mathrm{C}\right)$ deviates below the other points. A discussion of this deviation can be found on page 36 . 


\section{APPENDIX B - SELECTED SPECTRA}

The following figures display experimental data gathered for this project. Data is shown in $5 \mathrm{~nm}$ increments.

\section{Exp 118, Zn(TTP) + 3-Phenylpyridine}






\section{Exp 144, Zn(TBPMPP) + 3-Phenylpyridine}

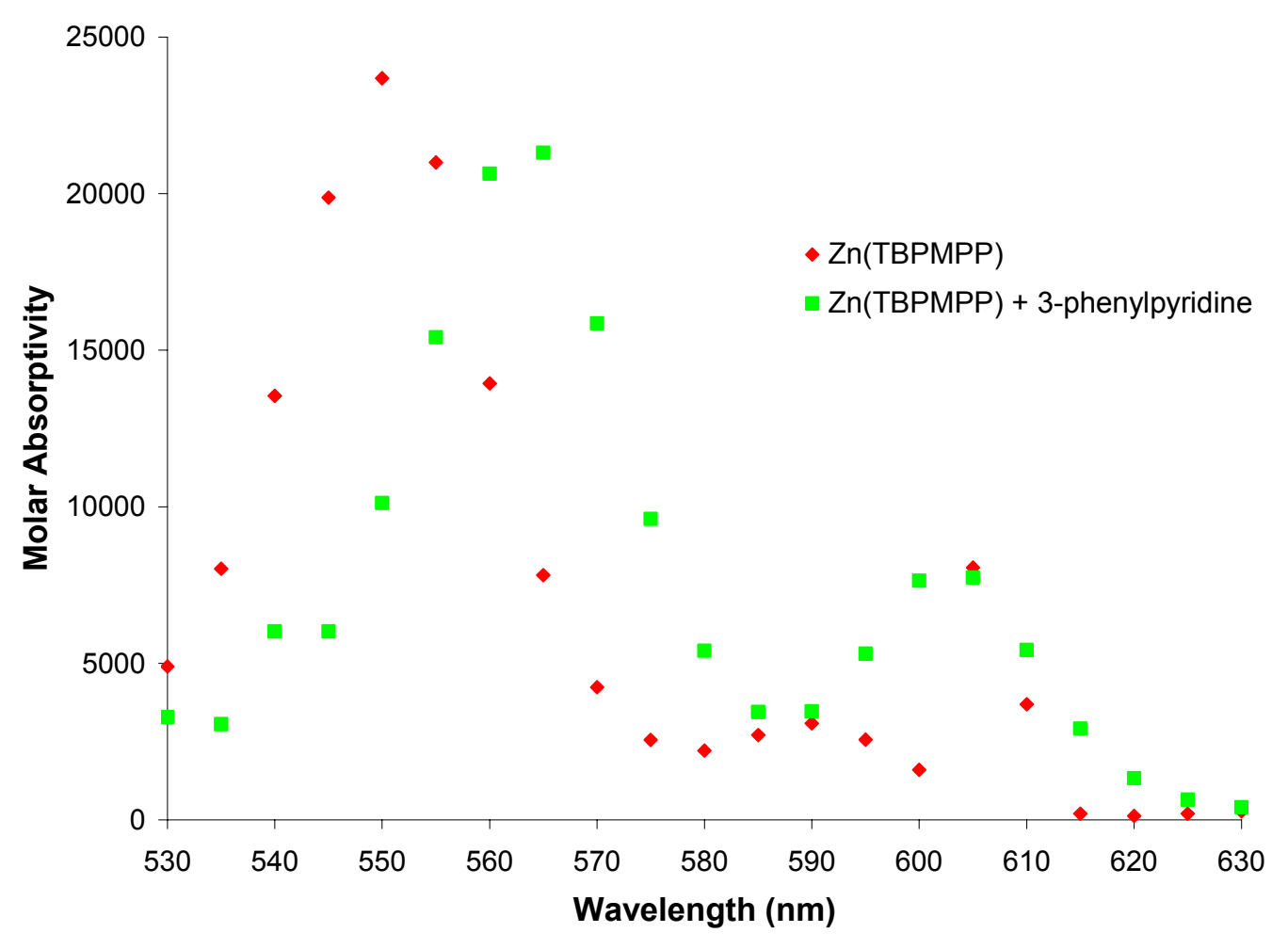




\section{Exp 173, Zn(T2,6FBzOPP) + 3-Phenylpyridine}

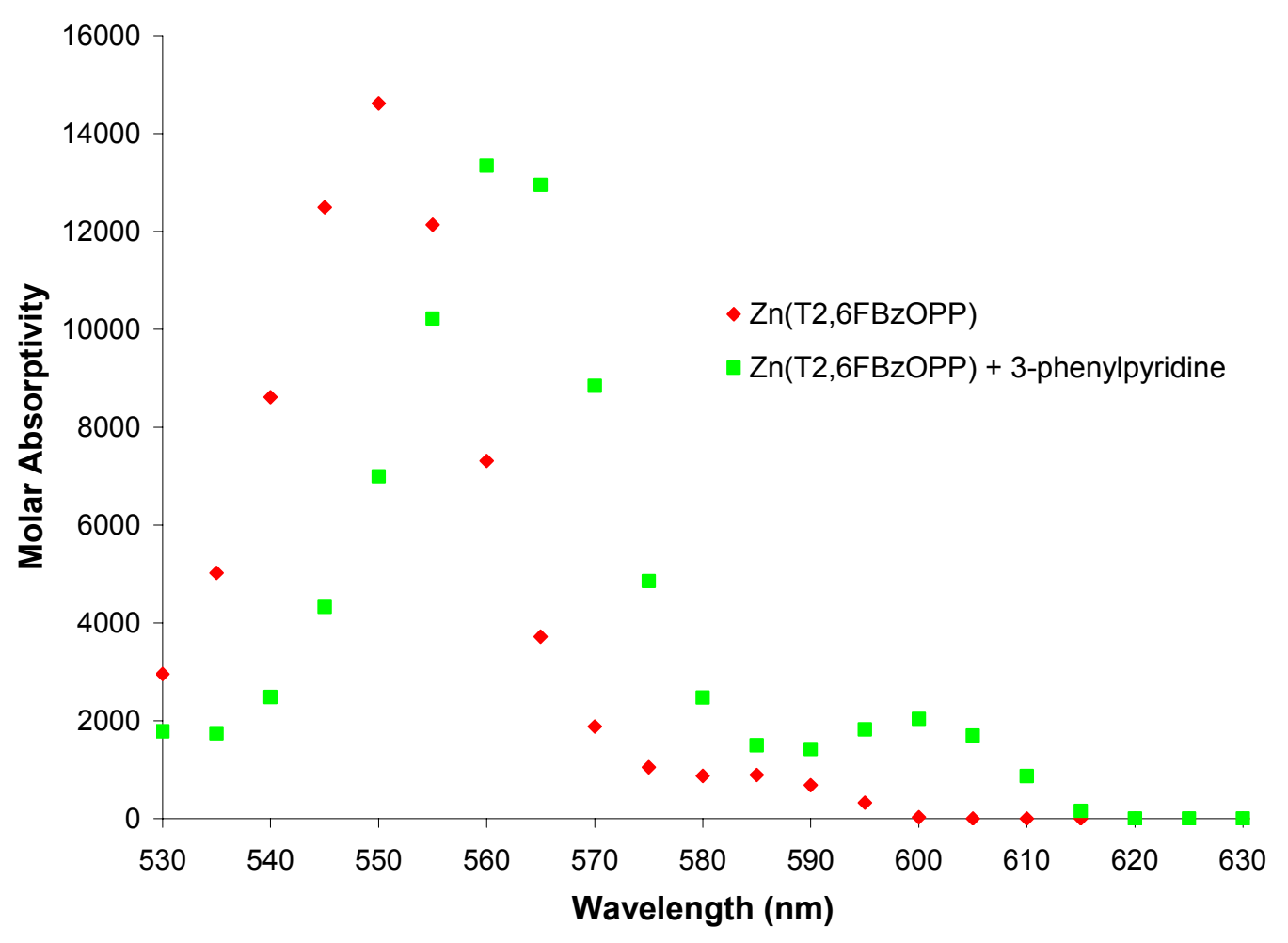




\section{Exp 188, Zn(T2,6MeOPP) + 3-Phenylpyridine}

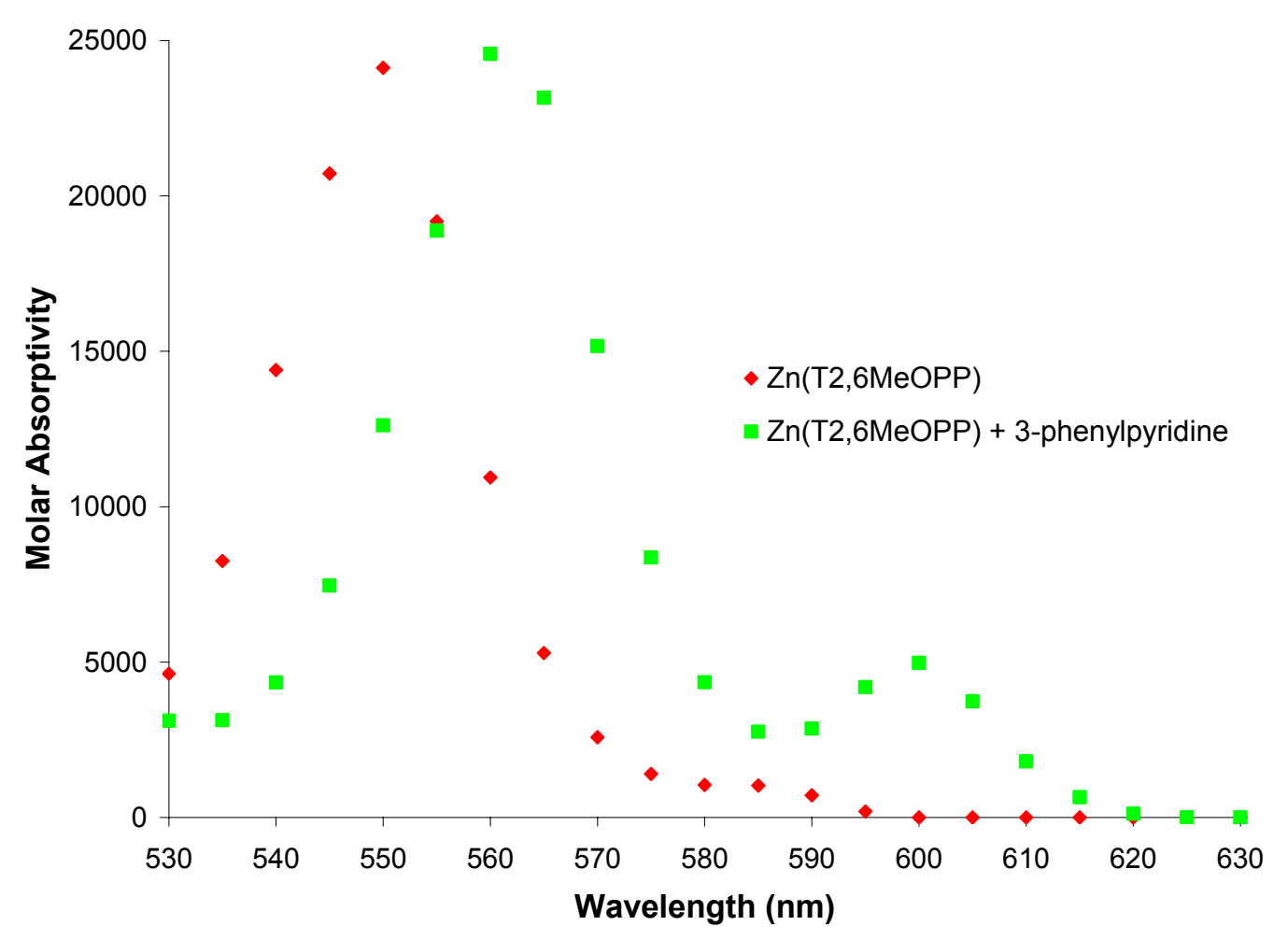


Exp 139, Zn(TTP) + Triphenylphosphine in Cyclohexane

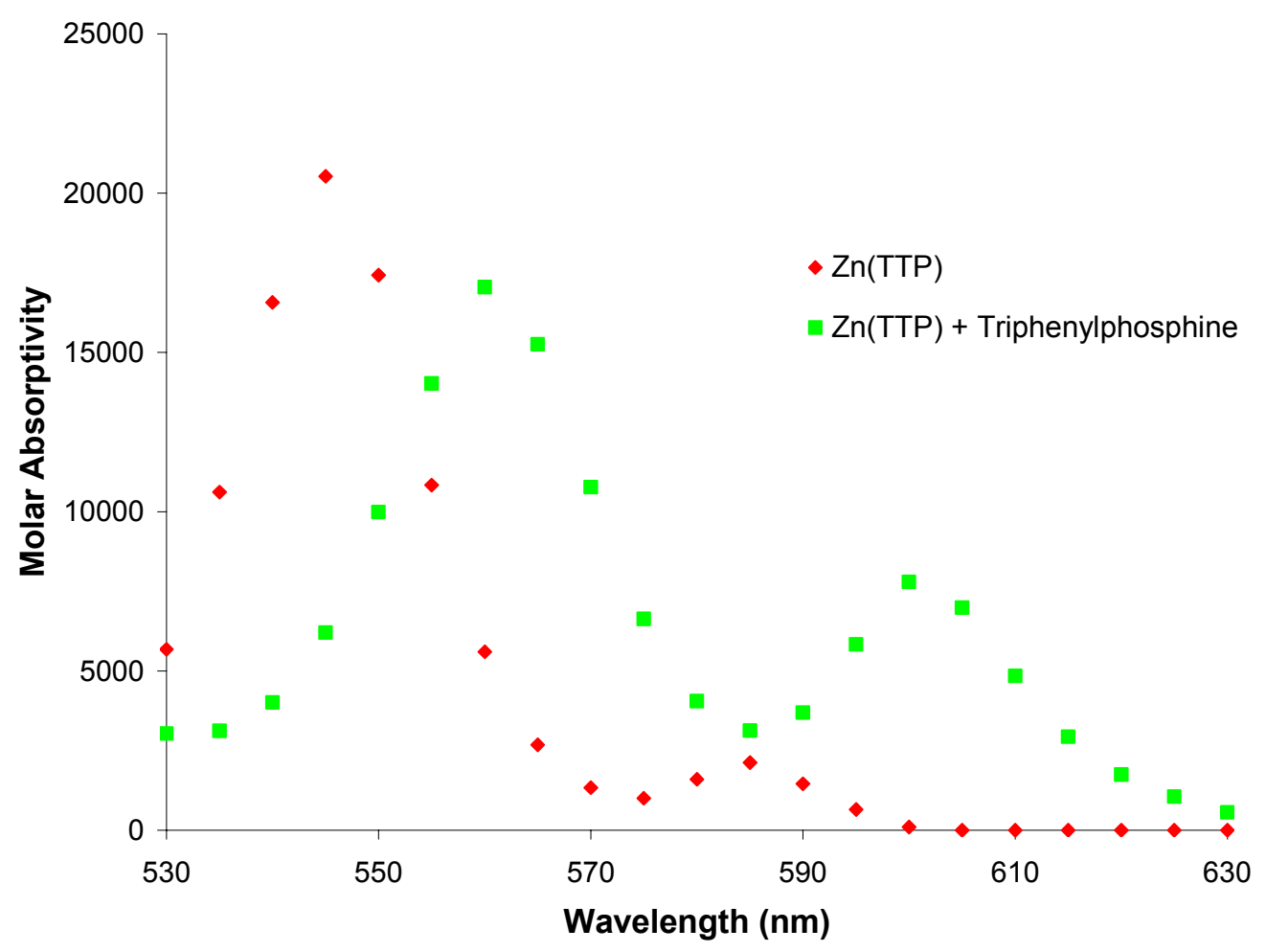




\section{Exp 154, Zn(TBPMPP) + Triphenylphosphine}

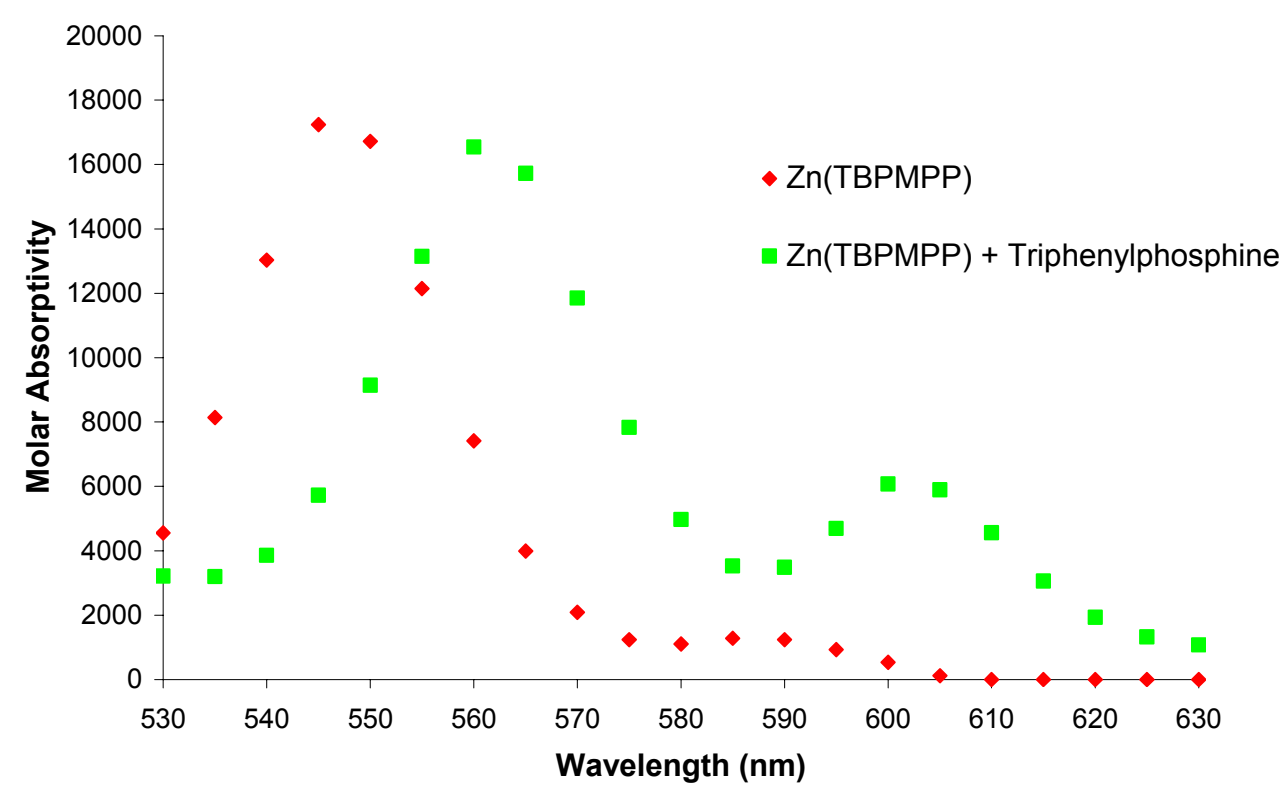




\section{Exp 241, Zn(TTP) + MethyIPN3}

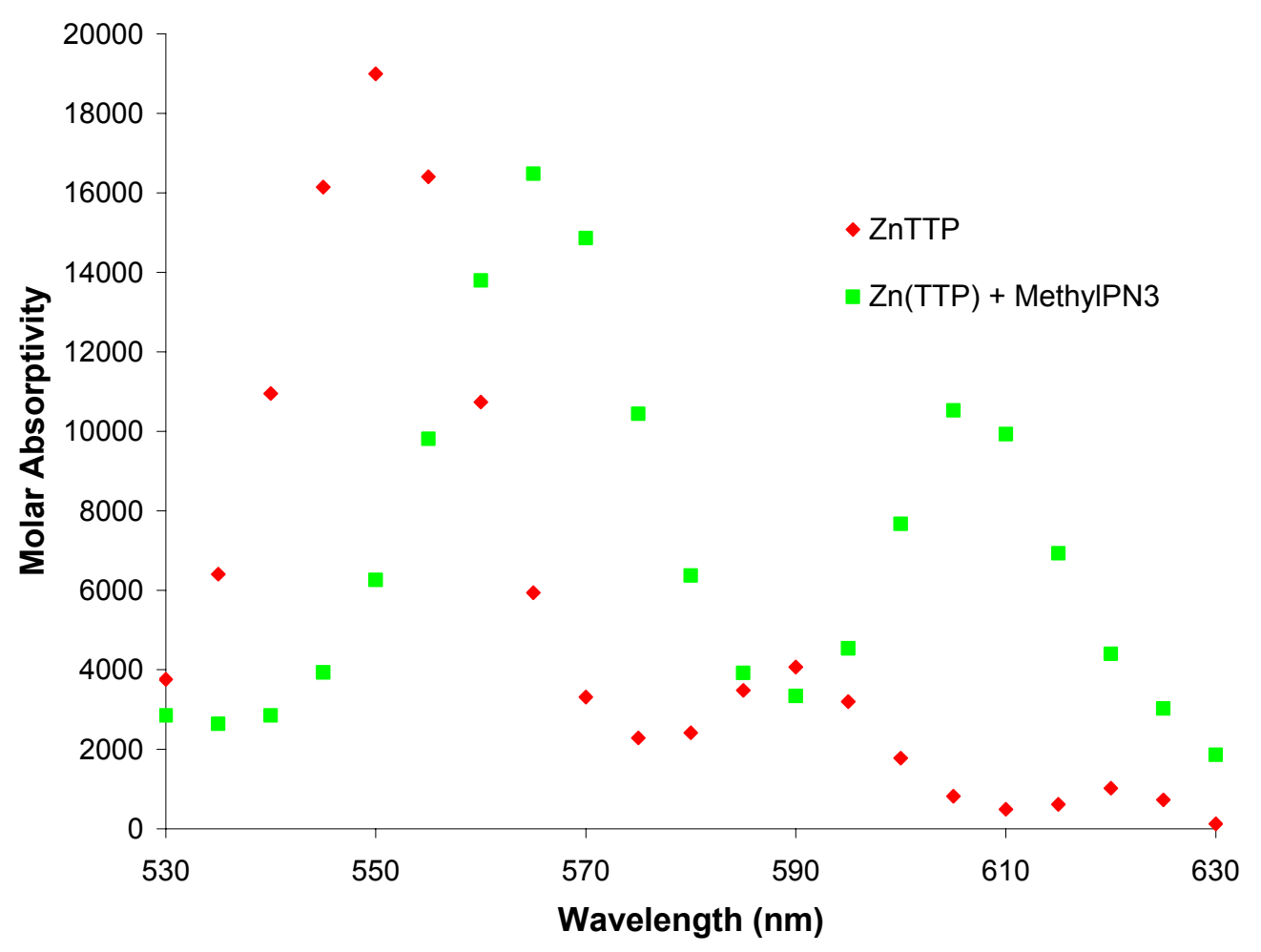




\section{Exp 243, Zn(T2,6MeOPP) + MethyIPN3}

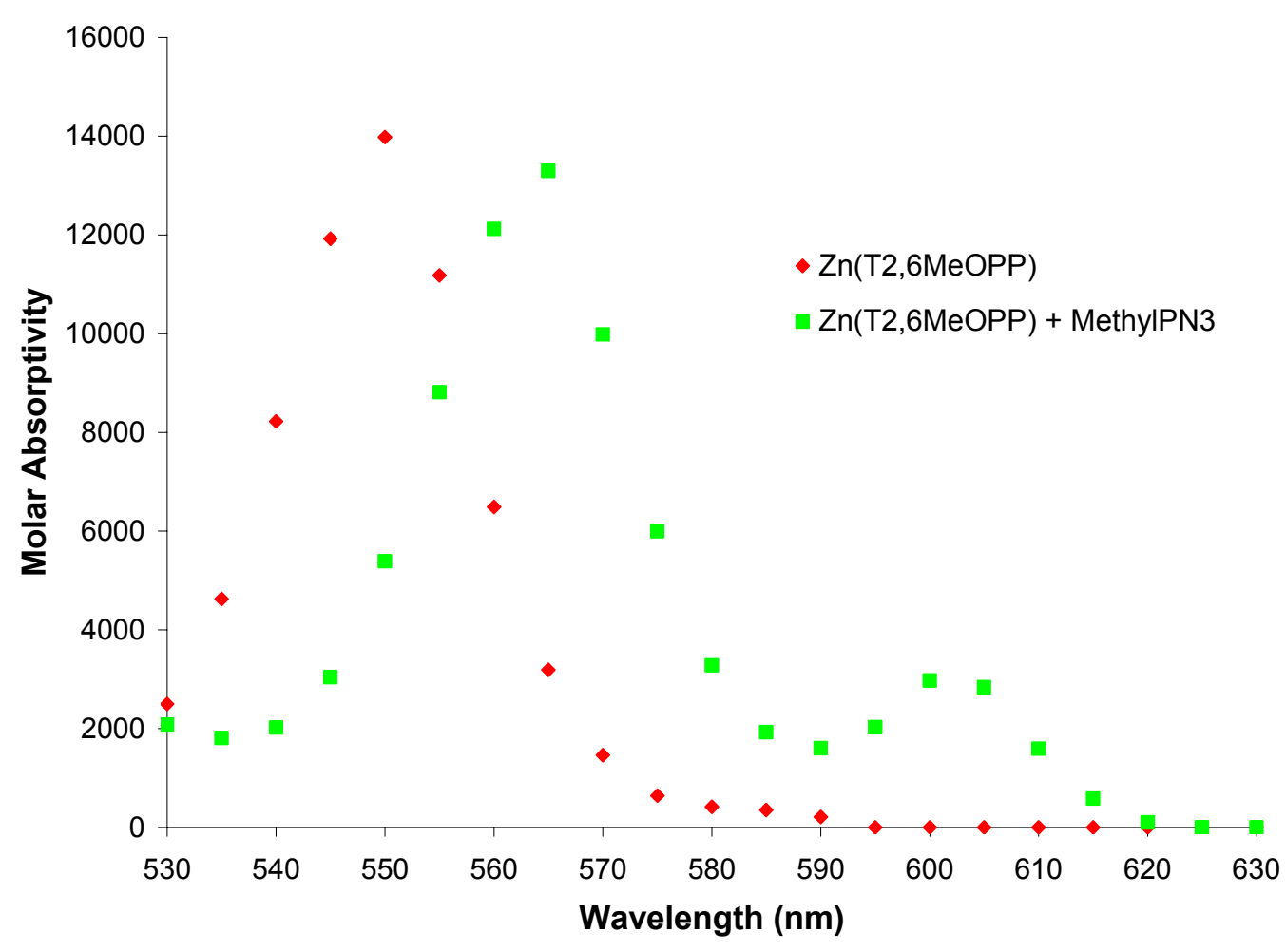




\section{Exp 245, Zn(TBPMPP) + MethyIPN3}

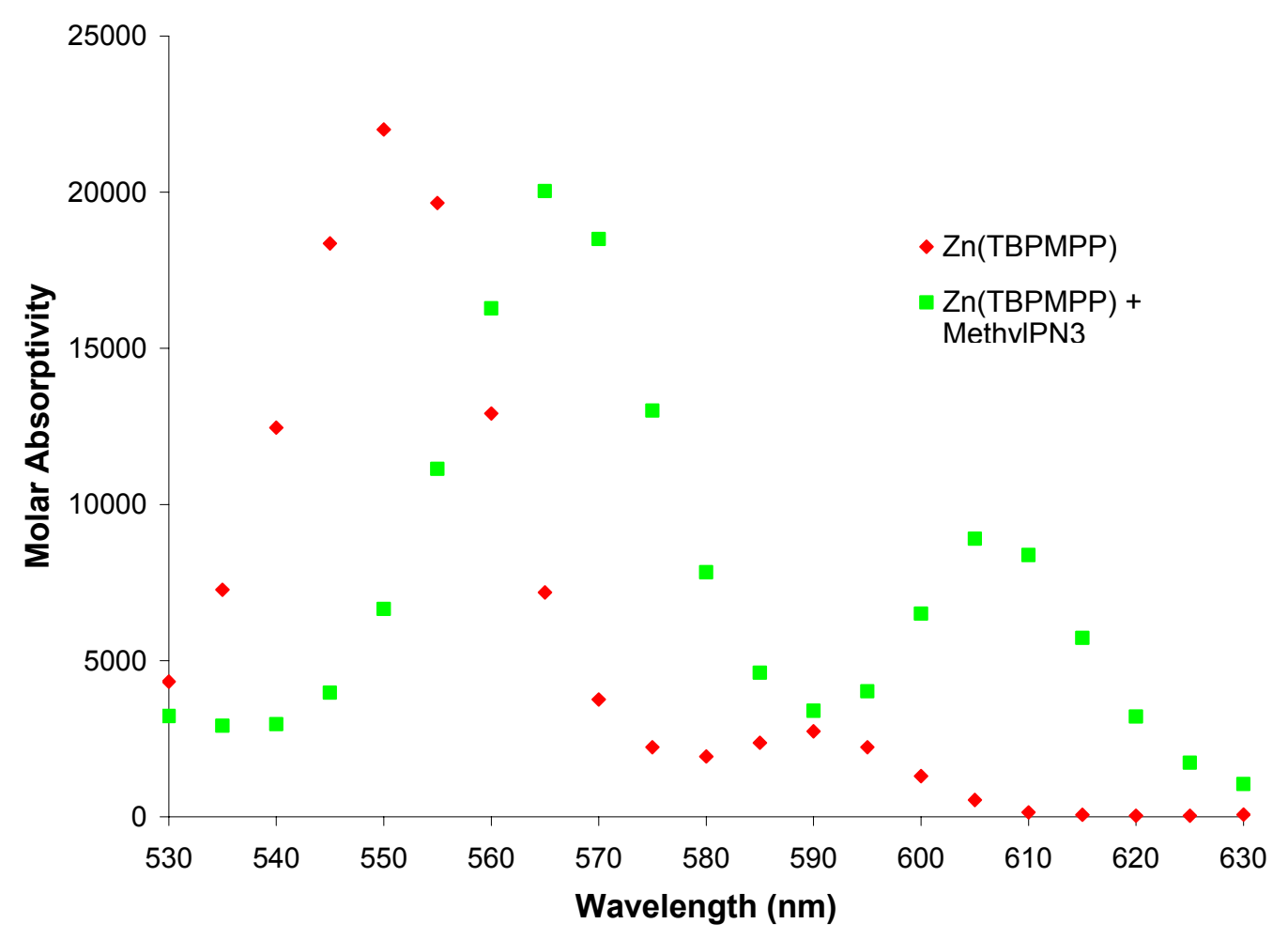




\section{APPENDIX C - COMPARISON OF SPECTRA}

\section{Comparison of Four-Coordinate Zinc Porphyrins}

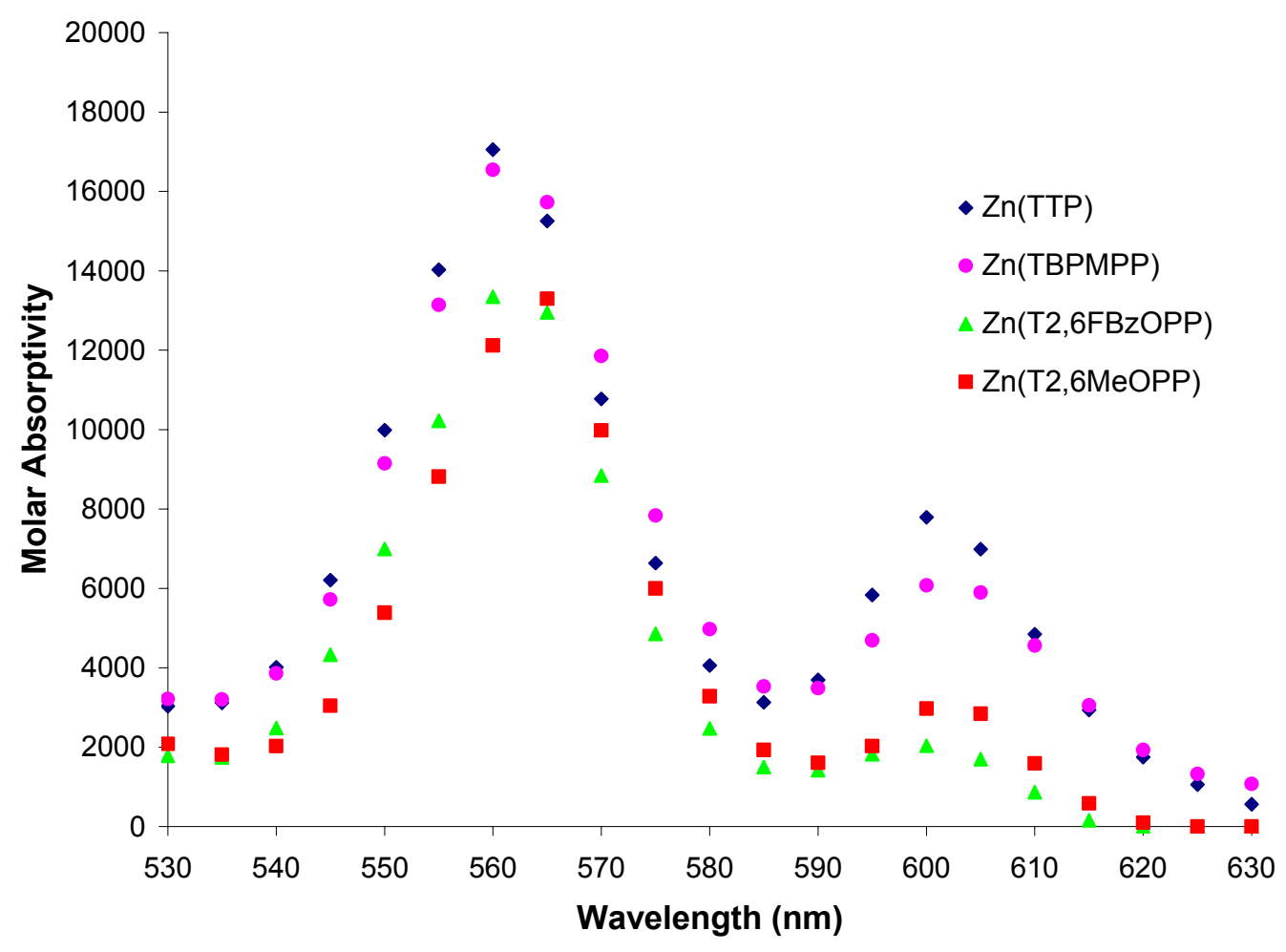




\section{Comparison of $\mathrm{Zn}(\mathrm{TTP})$ and $\mathrm{Zn}(\mathrm{TTP}) \mathrm{L}$}

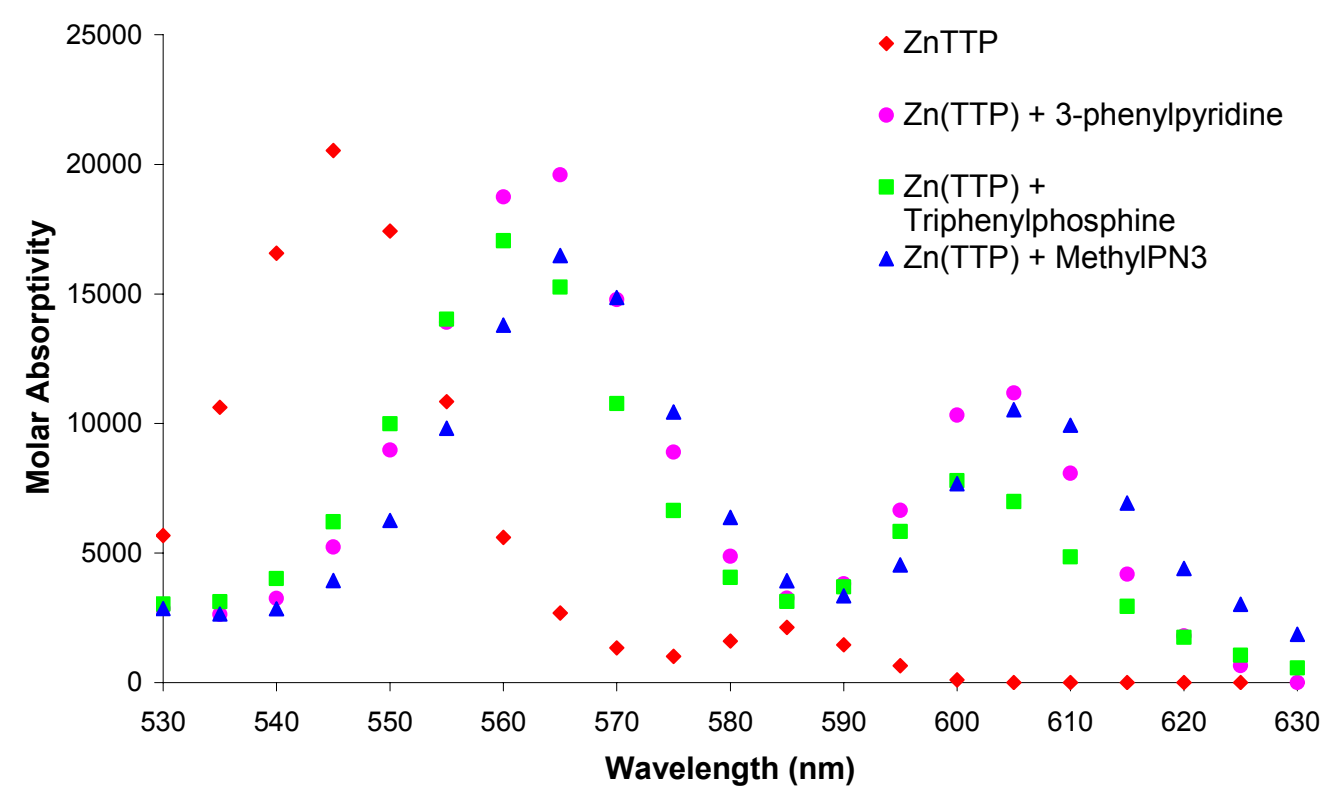




\section{Comparison of 3-Phenylpyridine-Zinc Porphyrin Complexes}

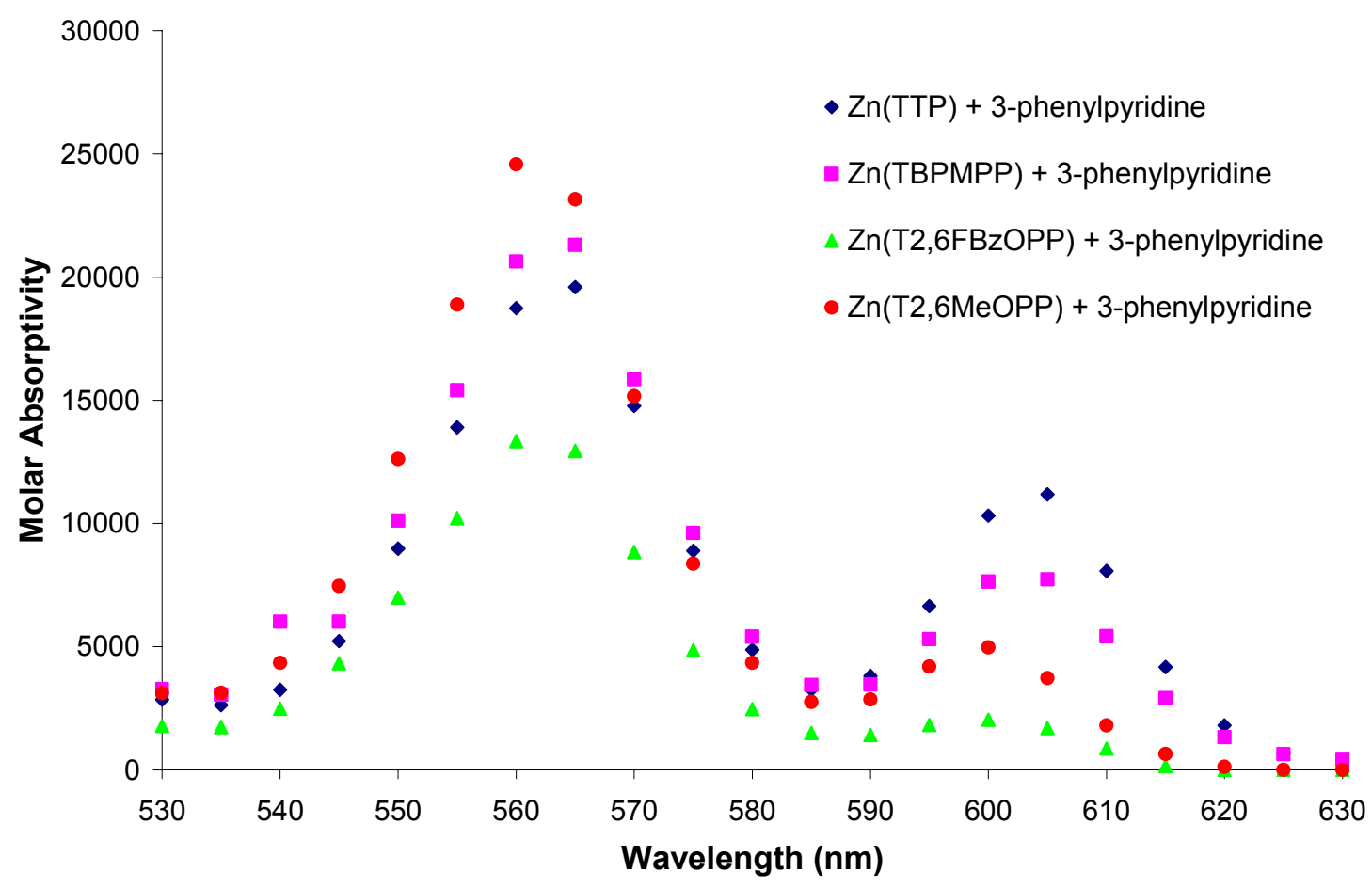




\section{APPENDIX D - EXAMPLE OF A SQUAD PROGRAM INPUT FILE}

The following is the SQUAD input file for Experiment 118, coordination of 3phenylpyridine to zinc tetra( $p$-tolyl)porphyrin.

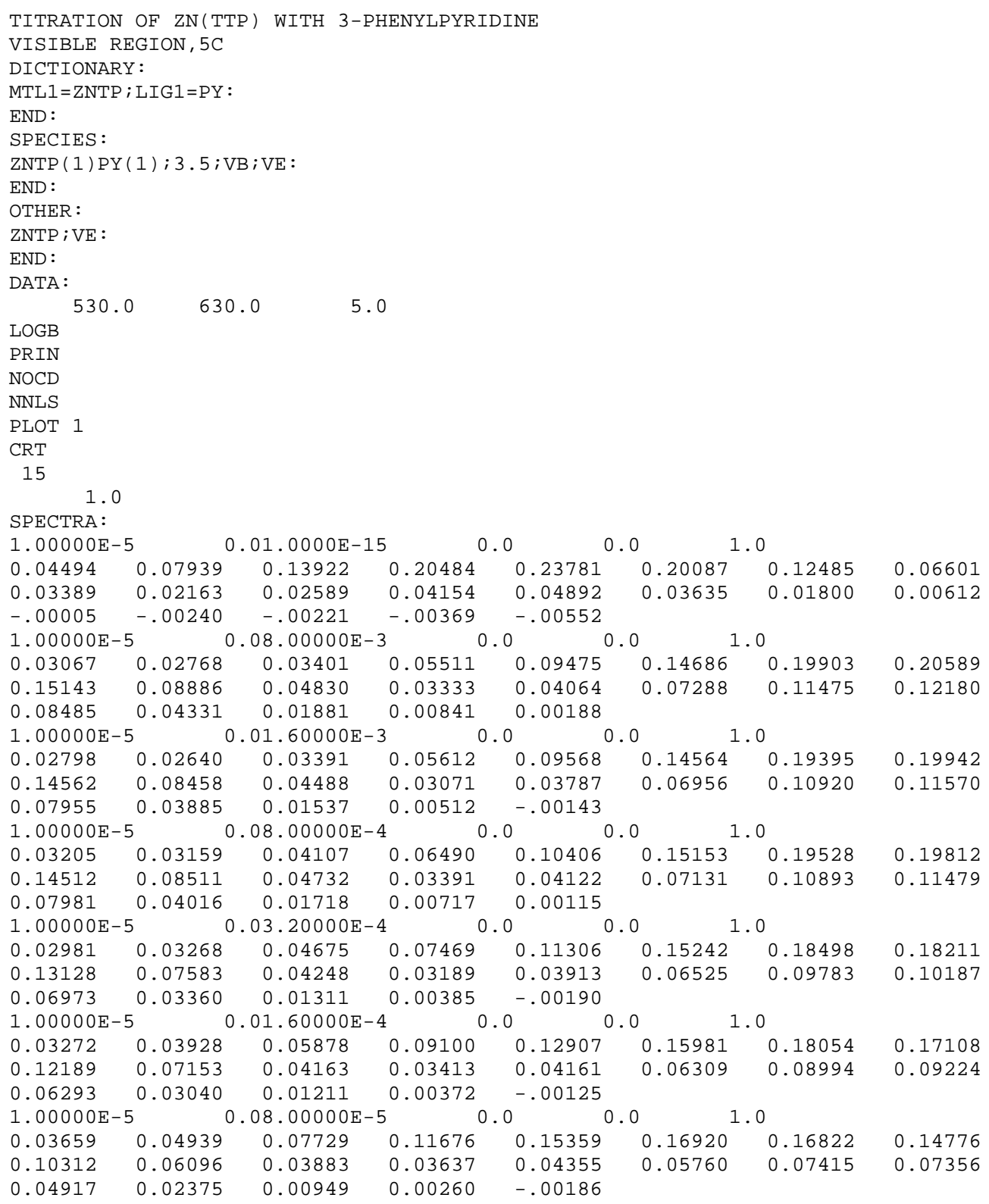

$\begin{array}{lllll}0.10312 & 0.06096 & 0.03883 & 0.03637 & 0.04355\end{array}$

$\begin{array}{lllll}0.04917 & 0.02375 & 0.00949 & 0.00260 & -.00186\end{array}$

01.0

$0.16920 \quad 0.16822 \quad 0.14776$

$-1.0$ 


\section{APPENDIX E - EXAMPLE OF A SQUAD PROGRAM OUTPUT FILE}

The following is the SQUAD output file for Experiment 118, coordination of 3phenylpyridine to zinc tetra( $p$-tolyl)porphyrin.

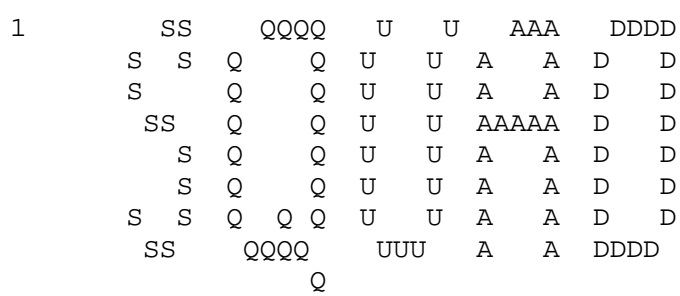

TITRATION OF ZN(TTP) WITH 3-PHENYLPYRIDINE

VISIBLE REGION, 5C

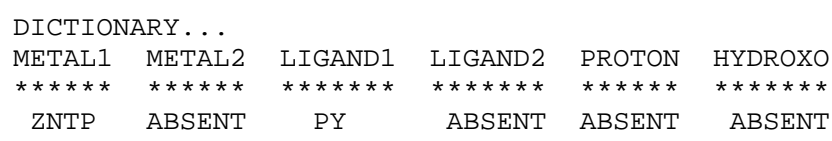



NUMBER OF METALS $=1$ NUMBER OF LIGANDS $=1$ NUMBER OF COMPLEXES $=1$

NUMBER OF CONSTANTS TO BE VARIED $=1$

NUMBER OF SETS OF MOLAR ABSORPTIVITIES TO BE FOUND $=2$

THE FOLLOWING MOL. ABS. OF THE COMPONENT(S) WILL BE VARIED.

I.E... ZNTP

THE MOL. ABS. OF ALL OTHER COMPONENTS WILL BE FIXED

THE FOLLOWING SPECIES AND/OR COMPLEXES HAVE FIXED (ZERO OR READ IN) MOL. ABS.

PY

THE FOLLOWING PRINT-OUT AND CALCULATION OPTIONS ARE IN EFFECT:-

LOGARITHMIC STABILITY CONSTANTS WILL BE REFINED

FULL INPUT DATA WILL BE PRINTED OUT

NO CARDS WILL BE PRODUCED

MOLAR ABSORPTIVITIES WILL BE CALCULATED USING THE NON-NEGATIVE LINEAR LEAST SQUARES ALGORITHM

EACH SPECTRUM WILL BE DISPLAYED AS A PRINTER PLOT

*** BRONSTED CONSTANTS WILL BE CALCULATED ***

NUMBER OF CYCLES DESIRED $=15$ 
TEMPERATURE IS 25. ODEGREE C

SPECTRAL REGION COVERED IS 530.0 TO 630.๑ AT 5.0 INTERVALS

KNOWN AND FIXED MOLAR ABSORPTIVITIES

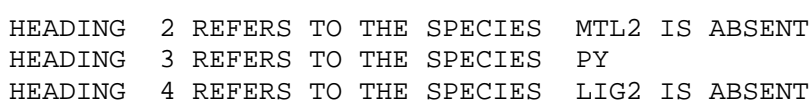

\begin{tabular}{|c|c|c|c|}
\hline & 2 & 3 & 4 \\
\hline 530.00 & $\odot . \odot \odot \odot \odot D+\odot \odot$ & $\odot . \odot \odot \odot \odot D+\odot \odot$ & $\odot . \odot \odot \odot \odot D+\odot \odot$ \\
\hline & $\odot . \odot \odot \odot \odot D+\odot \odot$ & $\odot . \odot \odot \odot \odot D+\odot \odot$ & $\odot . \odot \odot \odot \odot D+\odot \odot$ \\
\hline 40.00 & $\odot . \odot \odot \odot \odot D+\odot \odot$ & $\odot . \odot \odot \odot \odot D+\odot \odot$ & $\odot . \odot \odot \odot \odot D+\odot \odot$ \\
\hline $15 . \odot \odot$ & $\odot . \odot \odot \odot \odot D+\odot \odot$ & $\odot . \odot \odot \odot \odot D+\odot \odot$ & $\odot . \odot \odot \odot \odot D+\odot \odot$ \\
\hline $5 \odot .0 \odot$ & $\odot . \odot \odot \odot \odot D+\odot \odot$ & $\odot . \odot \odot \odot \odot D+\odot \odot$ & $\odot . \odot \odot \odot \odot D+\odot \odot$ \\
\hline 55.00 & $\odot . \odot \odot \odot \odot D+\odot \odot$ & $\odot . \odot \odot \odot \odot D+\odot \odot$ & $\odot . \odot \odot \odot \odot D+\odot \odot$ \\
\hline $.0 \odot$ & $\odot . \odot \odot \odot \odot D+\odot \odot$ & $\odot . \odot \odot \odot \odot D+\odot \odot$ & $\odot . \odot \odot \odot \odot D+\odot \odot$ \\
\hline $.0 \odot$ & $\odot . \odot \odot \odot \odot D+\odot \odot$ & $\odot . \odot \odot \odot \odot D+\odot \odot$ & $\odot . \odot \odot \odot \odot D+\odot \odot$ \\
\hline $.0 \odot$ & $\odot . \odot \odot \odot \odot D+\odot \odot$ & $\odot . \odot \odot \odot \odot D+\odot \odot$ & $\odot . \odot \odot \odot \odot D+\odot \odot$ \\
\hline.$\odot \odot$ & $\odot . \odot \odot \odot \odot D+\odot \odot$ & $\odot . \odot \odot \odot \odot D+\odot \odot$ & $\odot . \odot \odot \odot \odot D+\odot \odot$ \\
\hline & $\odot . \odot \odot \odot \odot D+\odot \odot$ & $\odot . \odot \odot \odot \odot D+\odot \odot$ & $\odot . \odot \odot \odot \odot D+\odot \odot$ \\
\hline .00 & $\odot . \odot \odot \odot \odot D+\odot \odot$ & $\odot . \odot \odot \odot \odot D+\odot \odot$ & $\odot . \odot \odot \odot \odot D+\odot \odot$ \\
\hline.$\odot \odot$ & $\odot . \odot \odot \odot \odot D+\odot \odot$ & $\odot . \odot \odot \odot \odot D+\odot \odot$ & $\odot . \odot \odot \odot \odot D+\odot \odot$ \\
\hline 95.00 & $\odot . \odot \odot \odot \odot D+\odot \odot$ & $\odot . \odot \odot \odot \odot D+\odot \odot$ & $\odot . \odot \odot \odot \odot D+\odot \odot$ \\
\hline $0.0 \odot$ & $\odot . \odot \odot \odot \odot D+\odot \odot$ & $\odot . \odot \odot \odot \odot D+\odot \odot$ & $\odot . \odot \odot \odot \odot D+\odot \odot$ \\
\hline 605.00 & $\odot . \odot \odot \odot \odot D+\odot \odot$ & $\odot . \odot \odot \odot \odot D+\odot \odot$ & $\odot . \odot \odot \odot \odot D+\odot \odot$ \\
\hline & $\odot . \odot \odot \odot \odot D+\odot \odot$ & $\odot . \odot \odot \odot \odot D+\odot \odot$ & $\odot . \odot \odot \odot \odot D+\odot \odot$ \\
\hline & $\odot . \odot \odot \odot \odot D+\odot \odot$ & $\odot . \odot \odot \odot \odot D+\odot \odot$ & $\odot . \odot \odot \odot \odot D+\odot \odot$ \\
\hline & $\odot . \odot \odot \odot \odot D+\odot \odot$ & $\odot . \odot \odot \odot \odot D+\odot \odot$ & $\odot . \odot \odot \odot \odot D+\odot \odot$ \\
\hline 5.00 & $\odot . \odot \odot \odot \odot D+\odot \odot$ & $\odot . \odot \odot \odot \odot D+\odot \odot$ & $\odot . \odot \odot \odot \odot D+\odot \odot$ \\
\hline 0.0 & $\odot . \odot \odot \odot \odot D+\odot \odot$ & $\odot . \odot \odot \odot \odot D+\odot \odot$ & $\odot . \odot \odot \odot \odot D+\odot \odot$ \\
\hline
\end{tabular}

COMPOSITION OF SOLUTIONS USED TO OBTAIN SPECTRA

\begin{tabular}{|c|c|c|c|c|c|c|}
\hline $\begin{array}{l}\text { SPECTRUM } \\
\text { NUMBER }\end{array}$ & METAL 1 & $\begin{array}{l}\text { METAL } 2 \\
- \text { MOLES PE }\end{array}$ & $\begin{array}{ll}\text { LIGAND } & 1 \\
\text { R LITER } & -.\end{array}$ & LIGAND 2 & $\mathrm{PH}$ & $\begin{array}{l}\text { PATHLENGTH } \\
\text { (CMS.) }\end{array}$ \\
\hline 1 & 1. $\odot \odot \odot \odot D-\odot 5$ & $\odot . \odot \odot \odot \odot D+\odot \odot$ & 1. $0 \odot \odot \odot D-15$ & $\odot . \odot \odot \odot \odot D+\odot \odot$ & $\odot . \odot \odot \odot$ & $\odot \odot$ \\
\hline 2 & 1. $\odot \odot \odot \odot D-\odot 5$ & $\odot . \odot \odot \odot \odot D+\odot \odot$ & 8.06 & $D+\odot \odot$ & $\odot . \odot \odot \odot$ & $\odot \odot$ \\
\hline 3 & 1. $000 \odot D-\odot 5$ & 0.006 & 1.6 & $\ominus \mathrm{D}+\odot \odot$ & 0. & $\odot \odot$ \\
\hline 4 & 1. $00 \odot \odot D-\odot 5$ & $\odot . \odot \odot \odot \odot D+\odot \odot$ & 8.00 & $\odot . \odot \odot \odot \odot D+\odot \odot$ & $\odot .00 \odot$ & 1.000 \\
\hline 5 & 1. $0 \odot \odot \odot D-\odot 5$ & $\odot . \odot \odot \odot \odot D+\odot \odot$ & $3.2000 \mathrm{D}-04$ & $\odot . \odot \odot \odot \odot D+\odot \odot$ & $0.00 \odot$ & 1.000 \\
\hline 6 & 1. $00 \odot \odot D-\odot 5$ & $\odot . \odot \odot \odot \odot D+\odot \odot$ & $1.600 \odot D-\odot 4$ & $\odot . \odot \odot \odot \odot D+\odot \odot$ & $\odot .00 \odot$ & 1.000 \\
\hline 7 & 1. $0000 \mathrm{D}-05$ & $\odot . \odot \odot \odot \odot D+\odot \odot$ & $8.0 \odot 0 \odot D-\odot 5$ & $\odot . \odot \odot \odot \odot D+\odot \odot$ & $\odot .00 \odot$ & 1.000 \\
\hline
\end{tabular}

BASELINE CORRECTION NOT APPLIED

1

INTERMEDIATE CALCULATIONS * * * * *

USER-SUPPLIED INITIAL ESTIMATES HAVE BEEN REPLACED

HESSIAN MATRIX APPROXIMATION

4. 474715D-02

ELEMENTS OF CONSTANT VECTOR

1. $067370 \mathrm{D}-02$ 


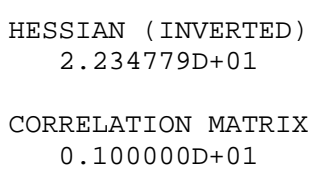

THE STANDARD DEVIATION IN THE ABSORBANCE DATA WITH THE INPUT CONSTANTS IS 5.3282D-03

THE STANDARD DEVIATION IN THE ABSORBANCE DATA IS $1.7255 \mathrm{D}-03$
4.2635
0.0082 SHIFT=
0.2385 FOR ZNTP(1)PY(1)

1 CYCLE(S) CALCULATED

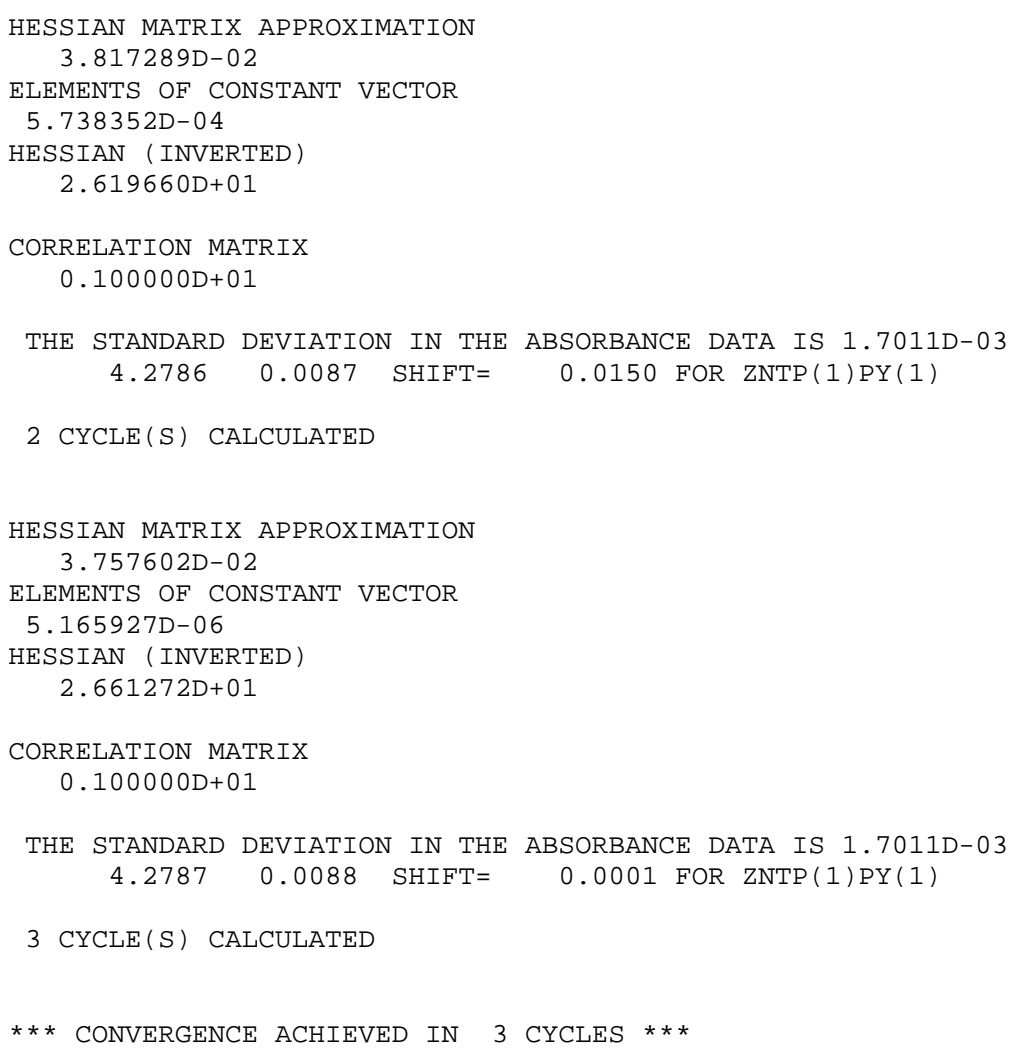

STAND. DEV. OF FIT FOR SPECTRUM NUMBER STAND. DEV. OF FIT FOR SPECTRUM NUMBER STAND. DEV. OF FIT FOR SPECTRUM NUMBER STAND. DEV. OF FIT FOR SPECTRUM NUMBER STAND. DEV. OF FIT FOR SPECTRUM NUMBER STAND. DEV. OF FIT FOR SPECTRUM NUMBER STAND. DEV. OF FIT FOR SPECTRUM NUMBER

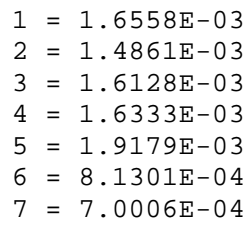

SUM OF SQUARES OF (OBSVD. - CALC. $)=3.0096 \mathrm{D}-\odot 4$ 


\begin{tabular}{|c|c|c|c|c|c|}
\hline & & FREE ZNTP & FREE MTL2 & FREE PY & FREE \\
\hline & 1 & 1. $0000 \mathrm{E}-05$ & $\odot . \odot \odot \odot \odot E+\odot \odot$ & $035 \mathrm{E}-16$ & $\odot E+\odot \odot$ \\
\hline & & $8 E-08$ & $\odot \odot \odot E+\odot \odot$ & $1 E-03$ & U \\
\hline & 3 & $3.2038 \mathrm{E}-07$ & $\odot . \odot \odot \odot \odot E+\odot \odot$ & $1.5903 \mathrm{E}-03$ & $+\odot \odot$ \\
\hline LN. & & $6.2421 \mathrm{E}-07$ & $\odot . \odot \odot \odot \odot E+\odot \odot$ & 7. $9062 E-\odot 4$ & $\odot$. \\
\hline $\mathrm{N}$ & & $1.4458 \mathrm{E}-06$ & $\odot .0 \odot \odot \odot E+\odot \odot$ & $3.1145 \mathrm{E}-04$ & $\mathrm{E}+0 \odot$ \\
\hline & Q & $2.5652 \mathrm{E}-06$ & $\odot \mathrm{E}+\Theta \odot$ & $57 E-\odot 4$ & $+\odot \odot$ \\
\hline & & 4.1516E- - 66 & $\odot . \odot \odot \odot \odot E+\odot \odot$ & $7.4152 \mathrm{E}-05$ & 0.0 \\
\hline
\end{tabular}

\begin{tabular}{lcc}
\multicolumn{3}{c}{ NSPECIES } \\
SOLN. & 1 & $1.5965 \mathrm{E}-16$ \\
SOLN. & 2 & $9.9346 \mathrm{E}-06$ \\
SOLN. & 3 & $9.6796 \mathrm{E}-06$ \\
SOLN. & 4 & $9.3758 \mathrm{E}-06$ \\
SOLN. & 5 & $8.5542 \mathrm{E}-06$ \\
SOLN. & 6 & $7.4348 \mathrm{E}-06$ \\
SOLN. & 7 & $5.8484 \mathrm{E}-06$
\end{tabular}

MOLAR ABSORPTIVITIES OF INDIVIDUAL SPECIES CALCULATED BY PROGRAM

USING NON-NEGATIVE LINEAR LEAST SQUARES ALGORITHM.

\begin{tabular}{|c|c|c|c|}
\hline HEADING & REFERS TO THE & SPECIES & ZNTP(1) \\
\hline HEADING & REFERS TO THE & SPECIES & ZNTP \\
\hline WAVELENGTH & 1 & & 2 \\
\hline 530.00 & $2.9225 \mathrm{D}+03$ & 4.4 & $1968 D+03$ \\
\hline 535.00 & $2.6367 \mathrm{D}+03$ & 7.9 & $484 D+03$ \\
\hline 540.00 & $3.2307 \mathrm{D}+03$ & 1.3 & $3917 D+\odot 4$ \\
\hline 545.00 & $5.3274 \mathrm{D}+03$ & 2.0 & $479 D+04$ \\
\hline 550.00 & $9.2900 \mathrm{D}+03$ & 2.3 & $3775 D+\odot 4$ \\
\hline 555.00 & 1. $4580 \mathrm{D}+\odot 4$ & 2.0 & $\odot 94 D+\odot 4$ \\
\hline $560.0 \odot$ & $1.9816 D+04$ & 1.2 & $500 D+\odot 4$ \\
\hline 565.00 & $2.0534 D+04$ & 6.6 & $\odot 89 D+03$ \\
\hline 570.00 & $1.509 \odot D+\odot 4$ & 3.4 & $1089 D+03$ \\
\hline 575.00 & $8.7928 D+03$ & 2.1 & $169 \odot D+\odot 3$ \\
\hline 580.00 & $4.7155 D+03$ & 2.5 & $5898 D+03$ \\
\hline 585.00 & $3.1932 \mathrm{D}+03$ & 4.1 & $506 \mathrm{D}+\odot 3$ \\
\hline 590.00 & $3.9199 D+03$ & 4.8 & $3874 D+03$ \\
\hline 595.00 & $7.2074 \mathrm{D}+03$ & 3.6 & $357 D+03$ \\
\hline 600.00 & $1.1378 D+\odot 4$ & 1.7 & $975 D+03$ \\
\hline 605.00 & $1.2086 D+04$ & 6.1 & $458 D+02$ \\
\hline 610.00 & $8.3828 D+03$ & 0.0 & $\odot \odot \odot D+\odot \odot$ \\
\hline 615.00 & $4.1431 D+03$ & 0.0 & $\odot \odot \odot D+\odot \odot$ \\
\hline 620.00 & $1.7031 \mathrm{D}+03$ & 0.0 & $\odot \odot \odot D+\odot \odot$ \\
\hline 625.00 & $6.2339 D+02$ & 0.0 & $\odot \odot \odot D+\odot \odot$ \\
\hline 630.00 & $\odot . \odot \odot \odot \odot D+\odot \odot$ & 0.0 & $\odot \odot \odot D+\odot \odot$ \\
\hline
\end{tabular}

STANDARD DEVN. OF CALCULATED MOLAR ABSORPTIVITIES

\begin{tabular}{|c|c|c|}
\hline WAVELENGTH & 1 & 2 \\
\hline 530.00 & $7.6898 D+01$ & $1.4395 \mathrm{D}+02$ \\
\hline 535.00 & $7.2253 D+01$ & 1. $3526 \mathrm{D}+\odot 2$ \\
\hline 540.00 & $7.3258 D+01$ & $1.3714 \mathrm{D}+02$ \\
\hline 545.00 & 7. $4412 \mathrm{D}+01$ & $1.3930 \mathrm{D}+\odot 2$ \\
\hline 550.00 & $7.2174 \mathrm{D}+01$ & 1. $3511 D+02$ \\
\hline 555.00 & $7.5117 D+01$ & 1. $4062 \mathrm{D}+\odot 2$ \\
\hline 560.00 & $8.9657 D+01$ & $1.6784 \mathrm{D}+02$ \\
\hline 565.00 & $9.4362 \mathrm{D}+01$ & $1.7664 \mathrm{D}+02$ \\
\hline 570.00 & $8.6331 D+01$ & 1. $6161 \mathrm{D}+02$ \\
\hline 575.00 & $7.6893 D+01$ & $1.4394 \mathrm{D}+\odot 2$ \\
\hline
\end{tabular}




\begin{tabular}{|c|c|c|}
\hline 580.00 & $6.7189 D+01$ & 1. $2578 \mathrm{D}+02$ \\
\hline 585.00 & $6.3853 D+01$ & $1.1953 \mathrm{D}+02$ \\
\hline 590.00 & $6.5827 D+01$ & 1. $2323 \mathrm{D}+02$ \\
\hline 595.00 & $6.2602 D+01$ & $1.1719 D+02$ \\
\hline 600.00 & $7.3582 D+01$ & $1.3774 \mathrm{D}+02$ \\
\hline 605.00 & $7.9074 \mathrm{D}+01$ & 1. $4802 \mathrm{D}+\mathrm{O} 2$ \\
\hline 610.00 & $7.2593 D+01$ & 1. $3589 \mathrm{D}+02$ \\
\hline 615.00 & $9.2399 \mathrm{D}+01$ & $1.7297 D+02$ \\
\hline 620.00 & $8.2203 D+01$ & $1.5388 \mathrm{D}+02$ \\
\hline 625.00 & $1.1110 \mathrm{D}+\odot 2$ & $2.0797 D+\odot 2$ \\
\hline 630.00 & $1.4995 \mathrm{D}+02$ & $2.8071 \mathrm{D}+02$ \\
\hline
\end{tabular}

1 PRINTER PLOT OF ALL MOLAR ABSORPTIVITIES

CHARACTER M IS USED TO REPRESENT THE SPECIES ZNTP

CHARACTER L IS USED TO REPRESENT THE SPECIES PY

CHARACTER 1 IS USED TO REPRESENT THE SPECIES ZNTP(1)PY(1)

$\begin{array}{lllllll}530.00 & 544.93 & 559.85 & 574.78 & 589.70 & 604.63 & 619.55\end{array}$

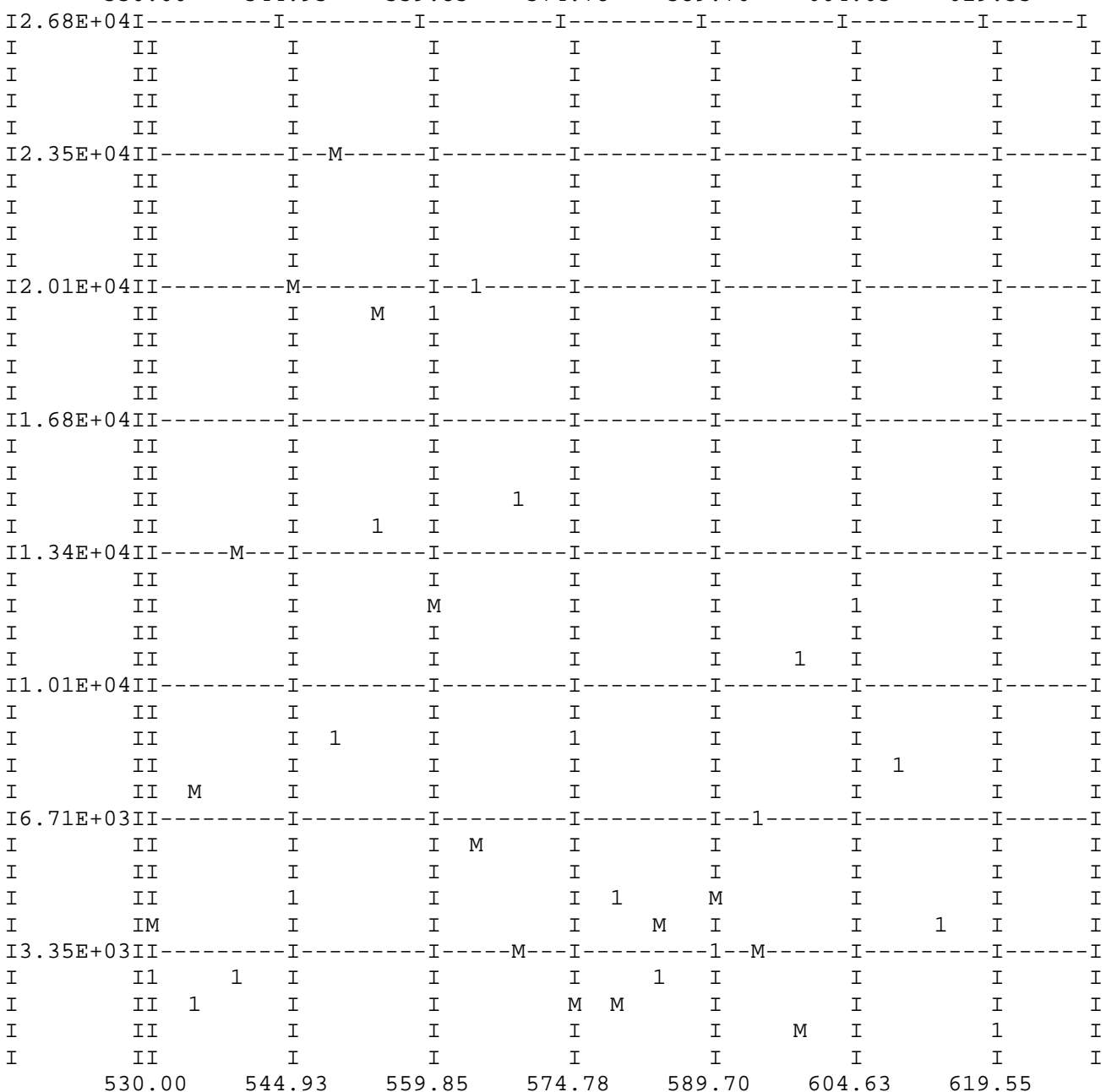

1 PRINTER PLOT OF ABSORBANCE DATA

SPECTRA 1 TO 7 ARE REPRESENTED BY SYMBOLS: -

$1,2,3,4,5,6,7$,

\begin{tabular}{|c|c|c|c|c|c|c|c|}
\hline & 530.00 & 544.93 & 559.85 & 574.78 & 589.70 & 604.63 & 619.55 \\
\hline 0.27 & I - - & $--I---$ & $---I---$ & $---I---$ & $---I---$ & $---I---$ & $---I---$ \\
\hline & II & I & I & I & I & I & I \\
\hline & II & I & I & I & I & I & I \\
\hline & II & I & I & I & I & I & I \\
\hline
\end{tabular}




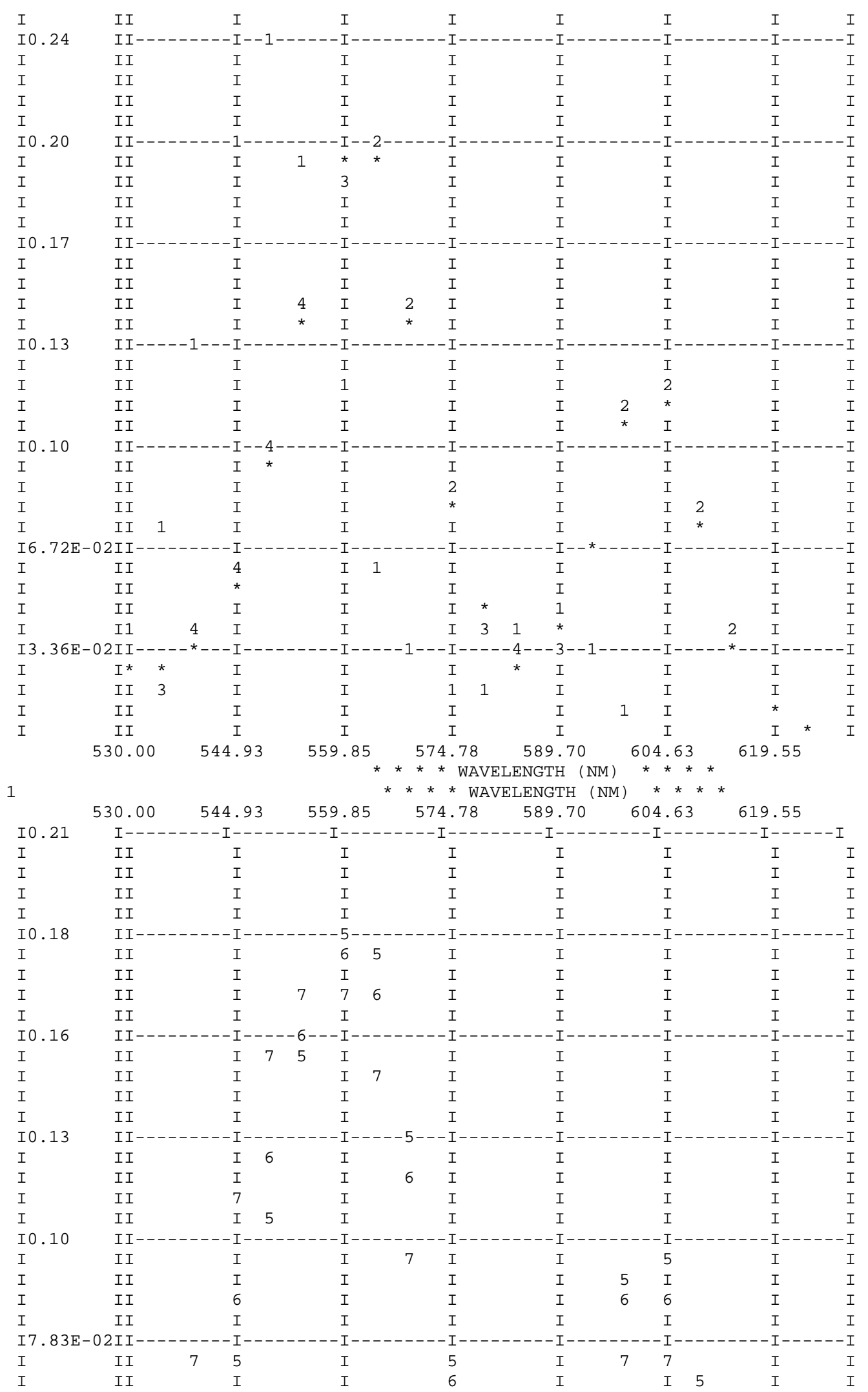




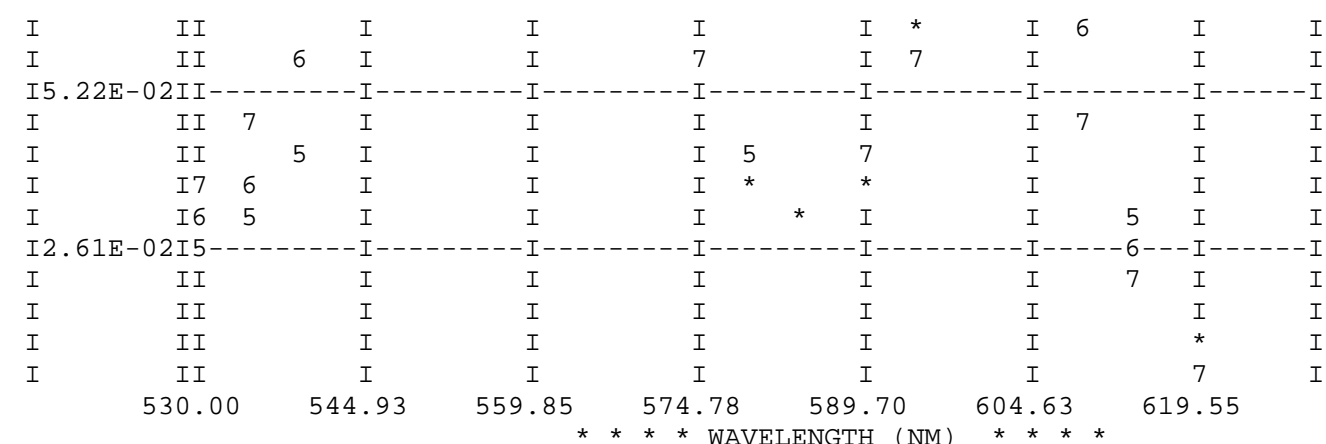

1 THE PRINTER PLOTS BELOW USE VARIOUS CHARACTERS TO SPECIFY THE FOLLOWING:CHARACTER E IS USED TO REPRESENT THE OBSERVED ABSORBANCES

CHARACTER T IS USED TO REPRESENT THE CALCULATED ABSORBANCES CHARACTER S IS USED TO INDICATE THAT A(OBS.) EQUALS A(CALC.) CHARACTER M IS USED TO REPRESENT THE SPECIES ZNTP CHARACTER L IS USED TO REPRESENT THE SPECIES PY CHARACTER 1 IS USED TO REPRESENT THE SPECIES ZNTP(1)PY(1)

1

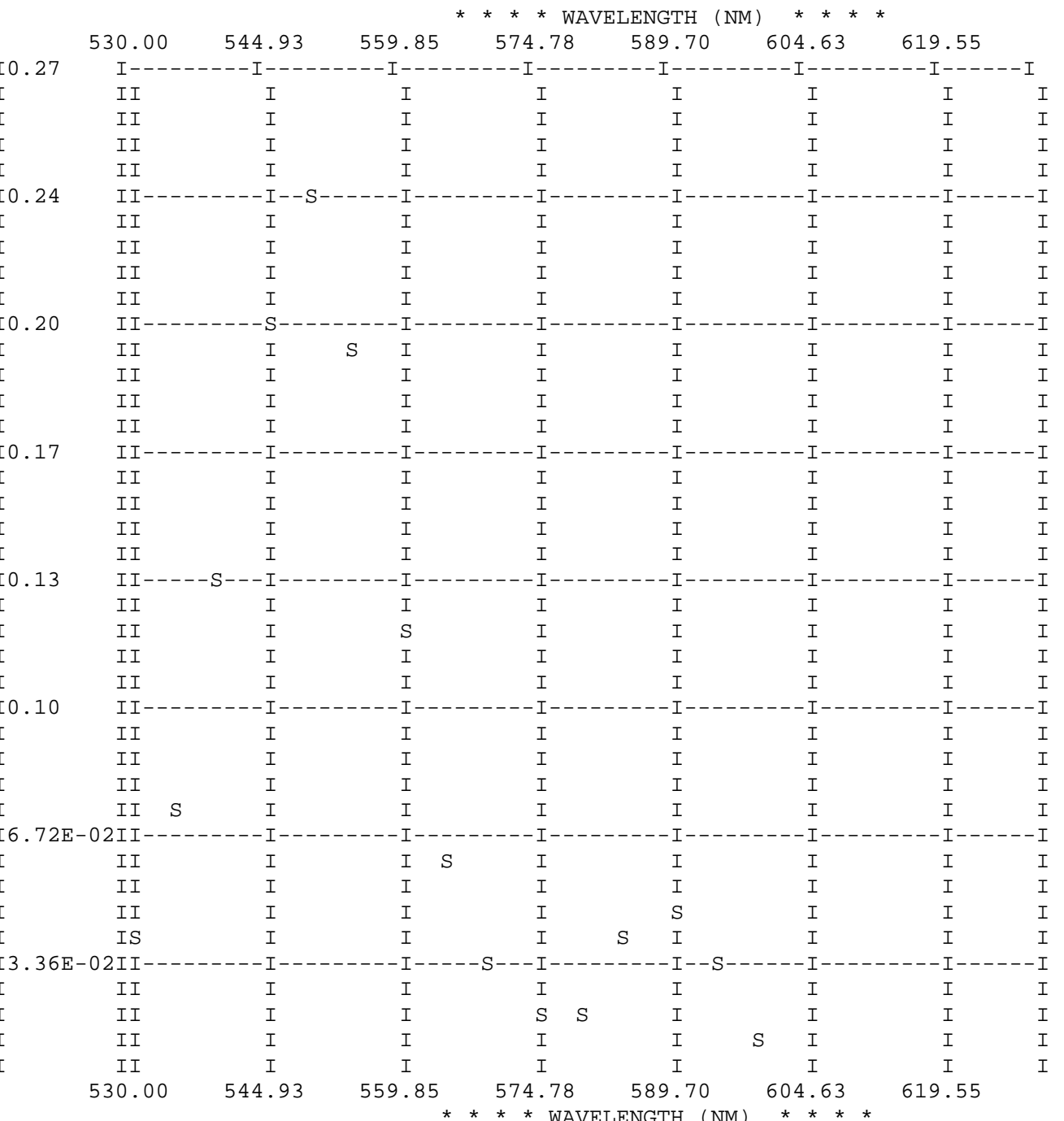

STANDARD DEVIATION OF ABSORBANCE FOR SOLUTION $1=1.6558 \mathrm{D}-03$ 
RESIDUALS FOR SPECTRUM NUMBER 1 POINT-BY-POINT

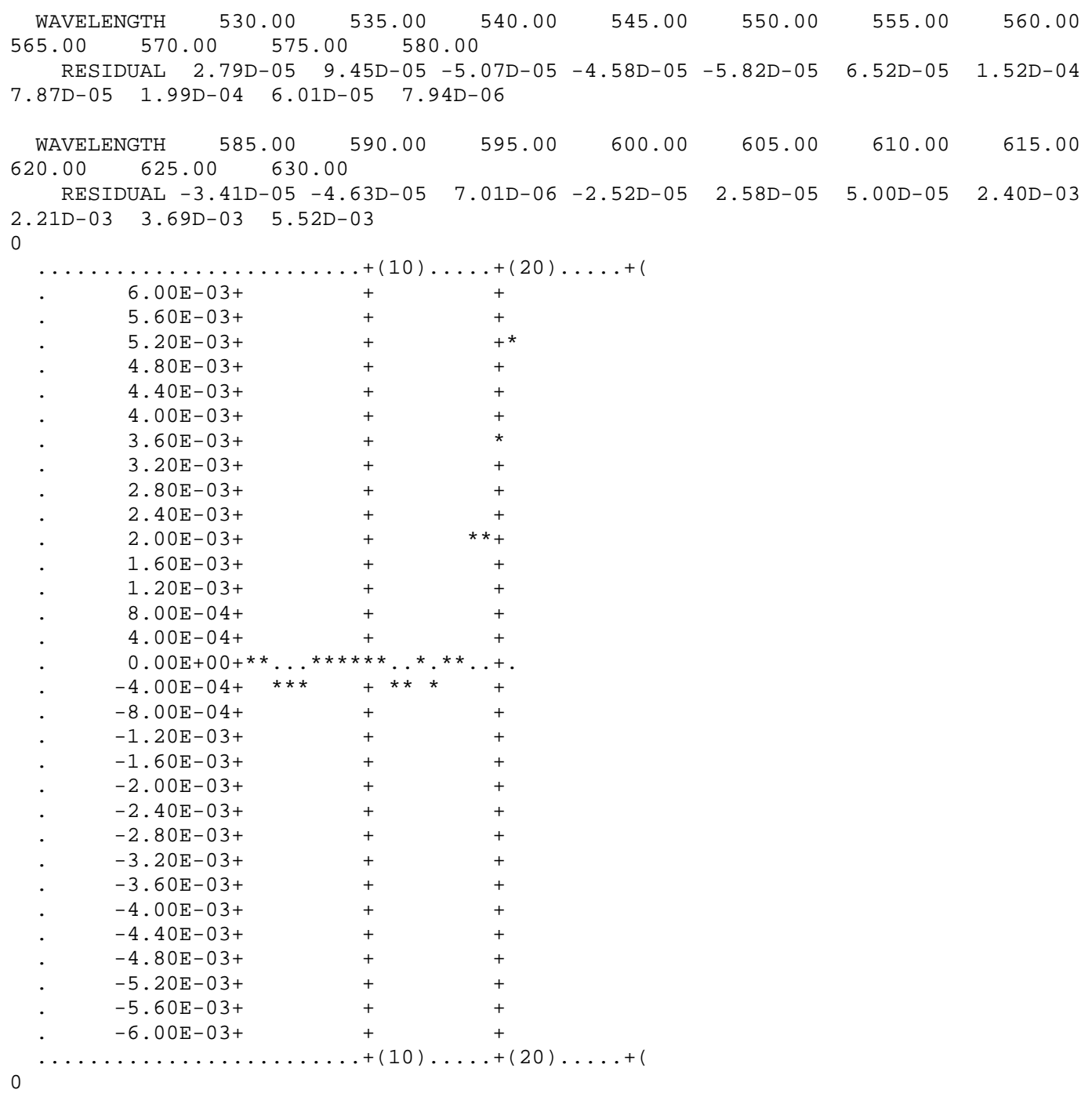

PERCENT CONTRIBUTION TO CALCULATED SPECTRUM NUMBER 1 FROM EACH SPECIES PRESENT IN SOLUTION

\begin{tabular}{|c|c|c|c|c|c|}
\hline & FREE ZNTP & FREE MTL2 & FREE PY & FREE LIG2 & - \\
\hline $530.0 \odot \odot$ & $10 \odot . \odot \odot \odot$ & $\odot . \odot \odot \odot$ & $\odot . \odot \odot \odot$ & $\odot . \odot \odot \odot$ & $\odot . \odot \odot \odot$ \\
\hline 35.000 & 63.867 & $\odot . \odot \odot \odot$ & $\odot .0 \odot \odot$ & $\odot .0 \odot \odot$ & $\odot .0 \odot \odot$ \\
\hline 40.000 & 52.791 & $\odot .0 \odot \odot$ & $\odot .0 \odot \odot$ & $\odot .0 \odot \odot$ & $\odot .00 \odot$ \\
\hline $545.00 \odot$ & 43.721 & $\odot . \odot \odot \odot$ & $\odot . \odot \odot \odot$ & 0.000 & $\odot .00 \odot$ \\
\hline $550.0 \odot \odot$ & 33.668 & $\odot . \odot \odot \odot$ & $\odot . \odot \odot \odot$ & $\odot .0 \odot \odot$ & $\odot . \odot \odot \odot$ \\
\hline $555.00 \odot$ & 22.151 & $\odot . \odot \odot \odot$ & $\odot . \odot \odot \odot$ & $\odot .0 \odot \odot$ & $\odot .00 \odot$ \\
\hline $560.00 \odot$ & 12.111 & $\odot .0 \odot \odot$ & $\odot .00 \odot$ & $\odot .0 \odot \odot$ & $0.00 \odot$ \\
\hline 565.000 & 6.018 & 0.000 & $\odot .000$ & $\odot .0 \odot \odot$ & 0.000 \\
\hline $570.0 \odot \odot$ & 3.011 & $\odot . \odot \odot \odot$ & $\odot . \odot \odot \odot$ & $\odot .0 \odot \odot$ & $\odot . \odot \odot \odot$ \\
\hline $575.0 \odot \odot$ & 1.880 & $\odot . \odot \odot \odot$ & $\odot . \odot \odot \odot$ & $\odot . \odot \odot \odot$ & $\odot . \odot \odot \odot$ \\
\hline $580.0 \odot \odot$ & 2.195 & $\odot .0 \odot \odot$ & $\odot .0 \odot \odot$ & $0.00 \odot$ & 0.000 \\
\hline $0 \odot \odot$ & 3.398 & $\odot . \odot \odot \odot$ & $\odot . \odot \odot \odot$ & $\odot .0 \odot \odot$ & $\odot . \odot \odot \odot$ \\
\hline $0 \odot \odot$ & 3.848 & 0.000 & 0.000 & 0.000 & $\odot .0 \odot \odot$ \\
\hline $595.00 \odot$ & 2.783 & $\odot . \odot \odot \odot$ & $\odot . \odot \odot \odot$ & $\odot . \odot \odot \odot$ & $\odot . \odot \odot \odot$ \\
\hline
\end{tabular}




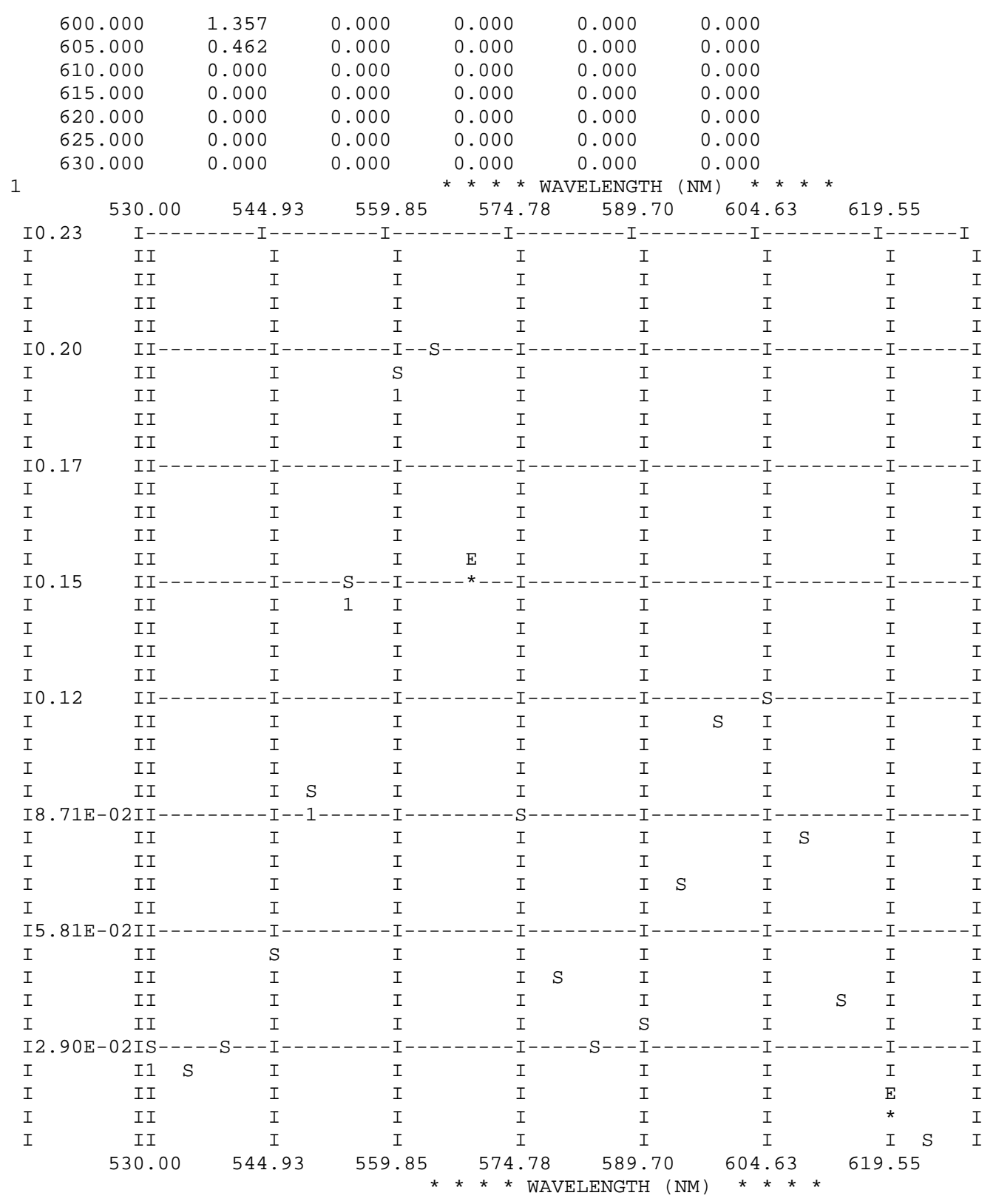

STANDARD DEVIATION OF ABSORBANCE FOR SOLUTION $2=1.4861 \mathrm{D}-03$

RESIDUALS FOR SPECTRUM NUMBER 2 POINT-BY-POINT

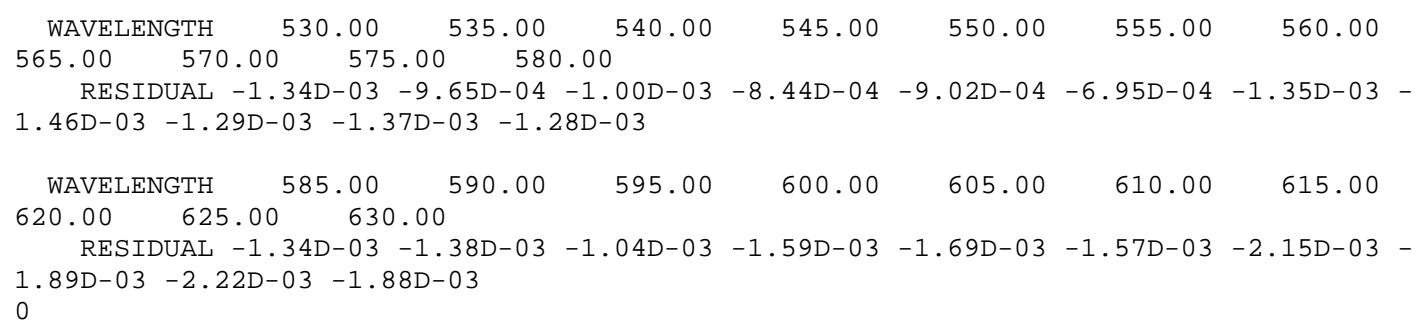




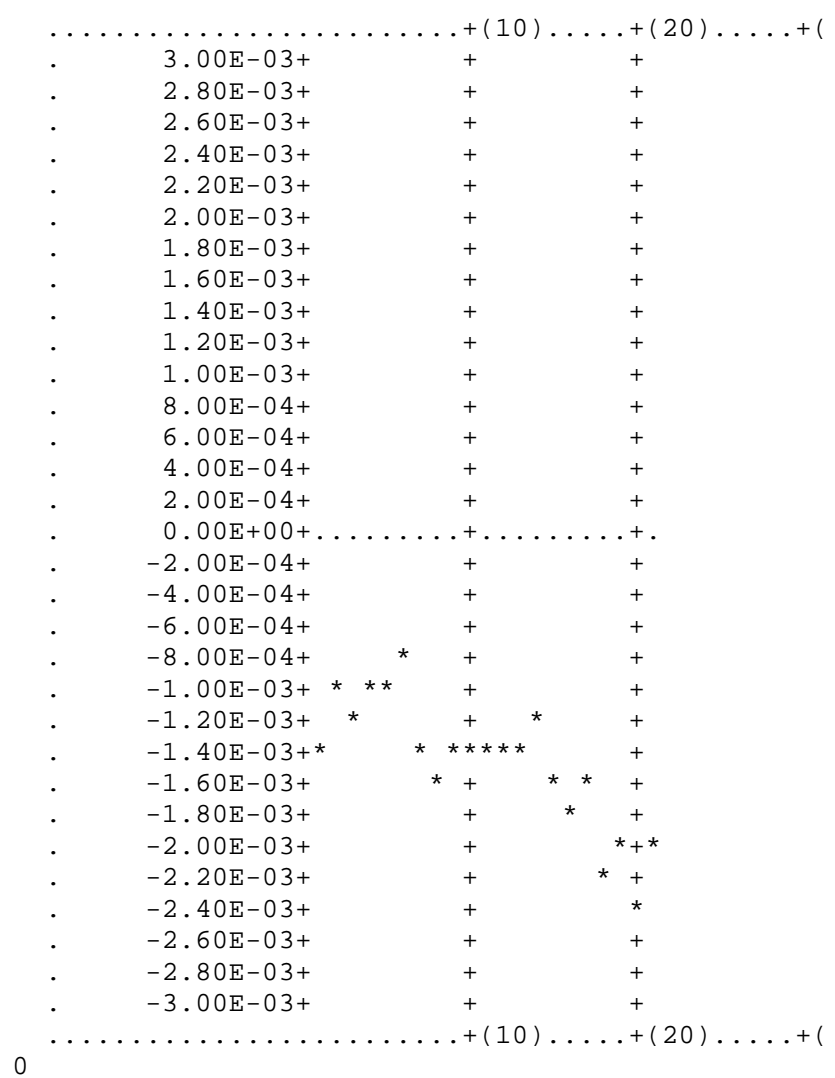

PERCENT CONTRIBUTION TO CALCULATED SPECTRUM NUMBER 2 FROM EACH SPECIES PRESENT IN SOLUTION

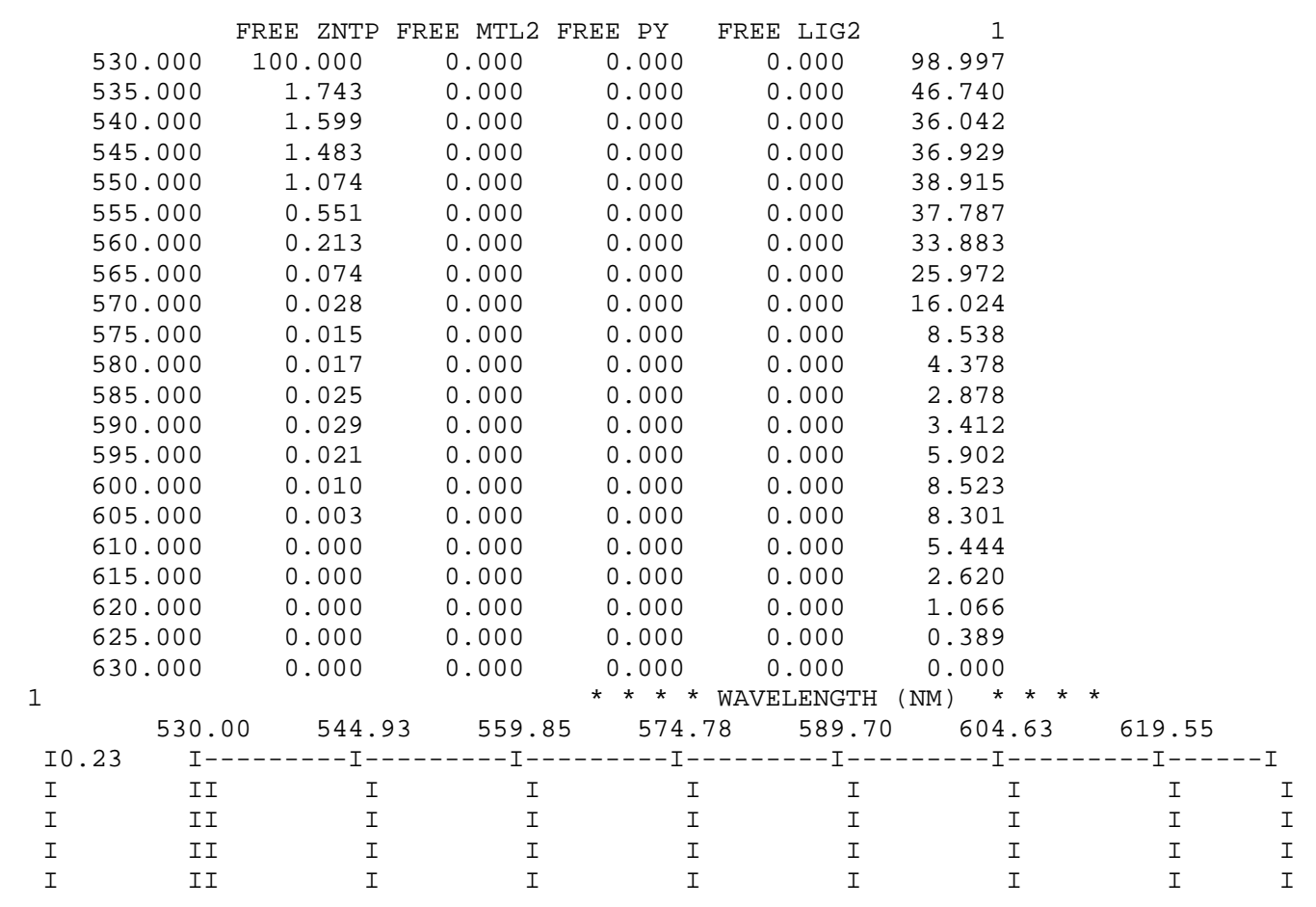




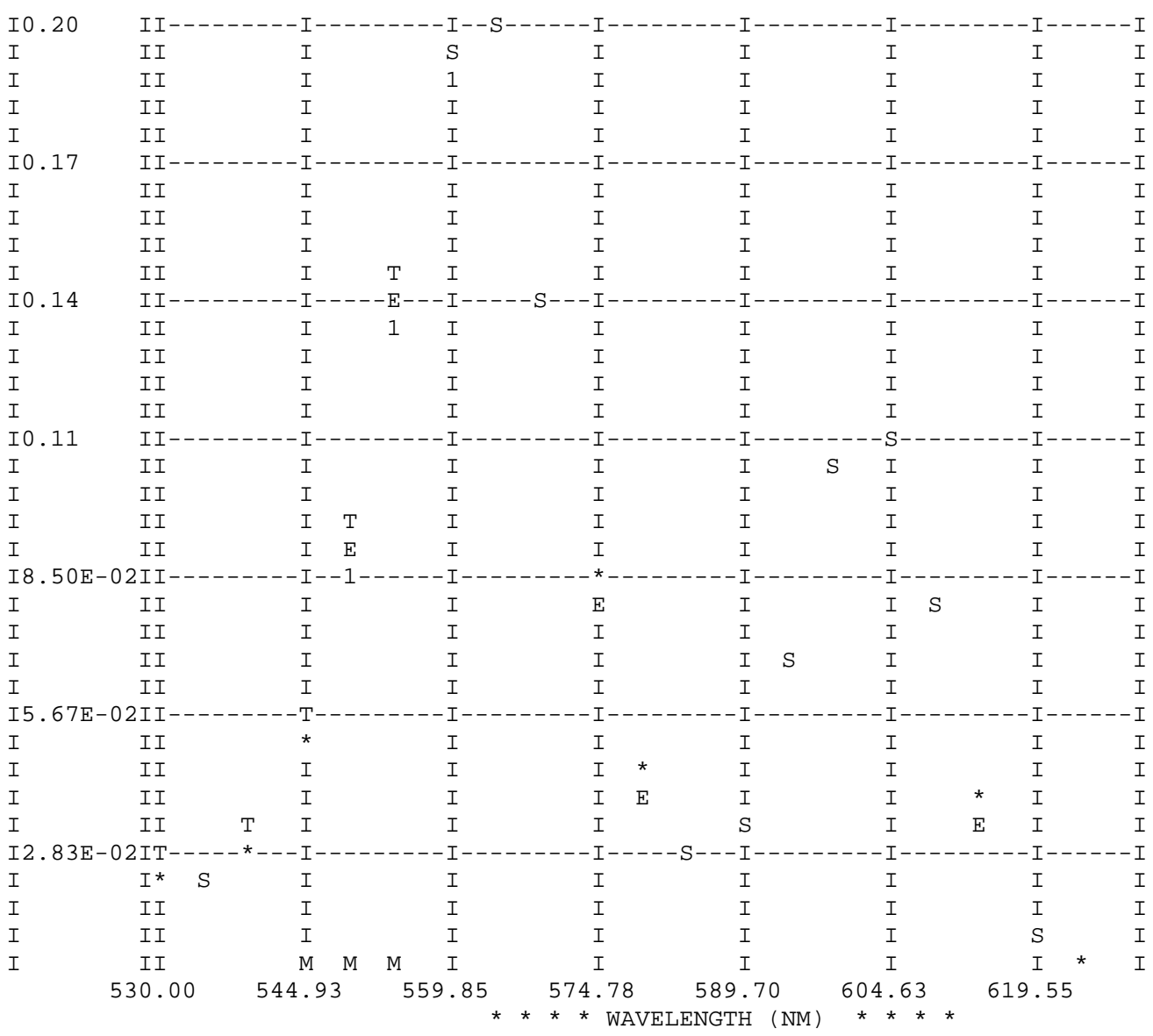

STANDARD DEVIATION OF ABSORBANCE FOR SOLUTION $3=1.6128 \mathrm{D}-03$

RESIDUALS FOR SPECTRUM NUMBER 3 POINT-BY-POINT

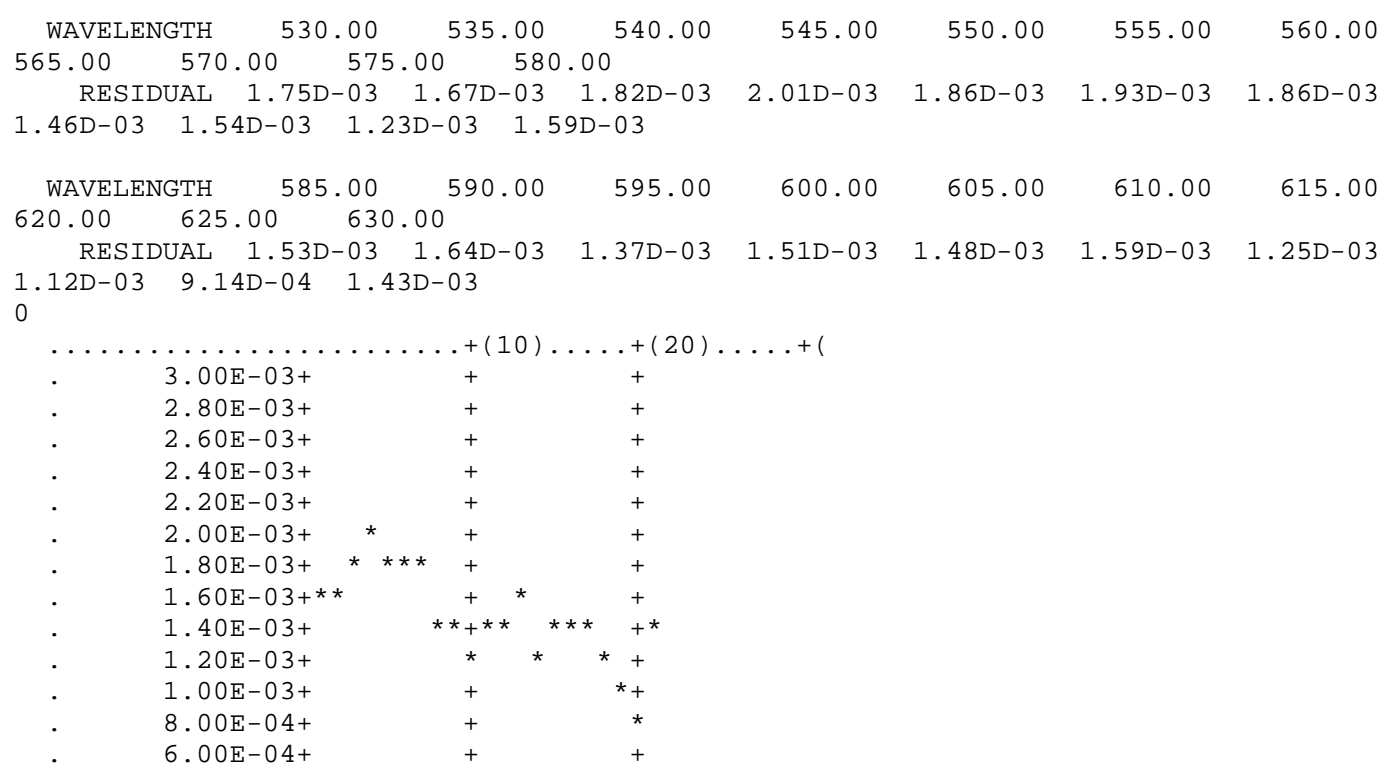




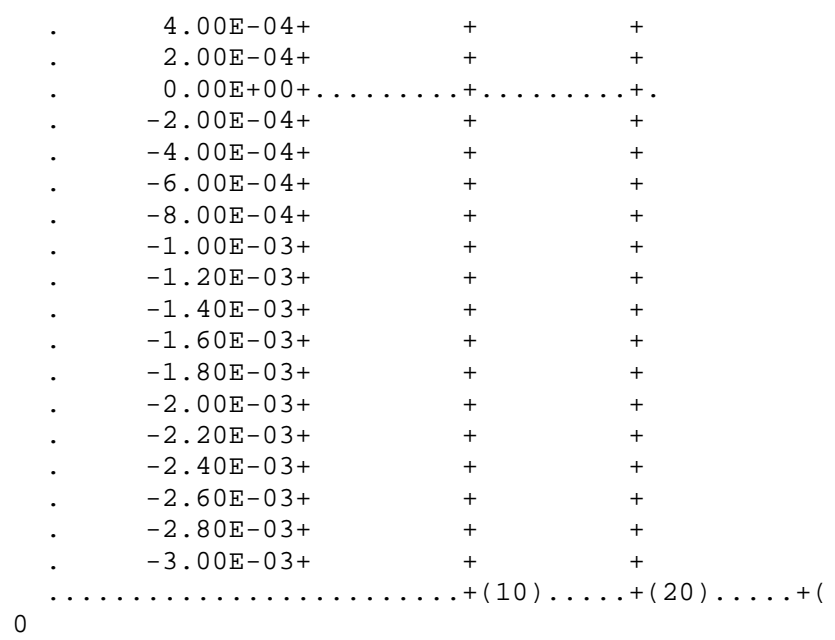

PRESENT IN SOLUTION

PERCENT CONTRIBUTION TO CALCULATED SPECTRUM NUMBER 3 FROM EACH SPECIES

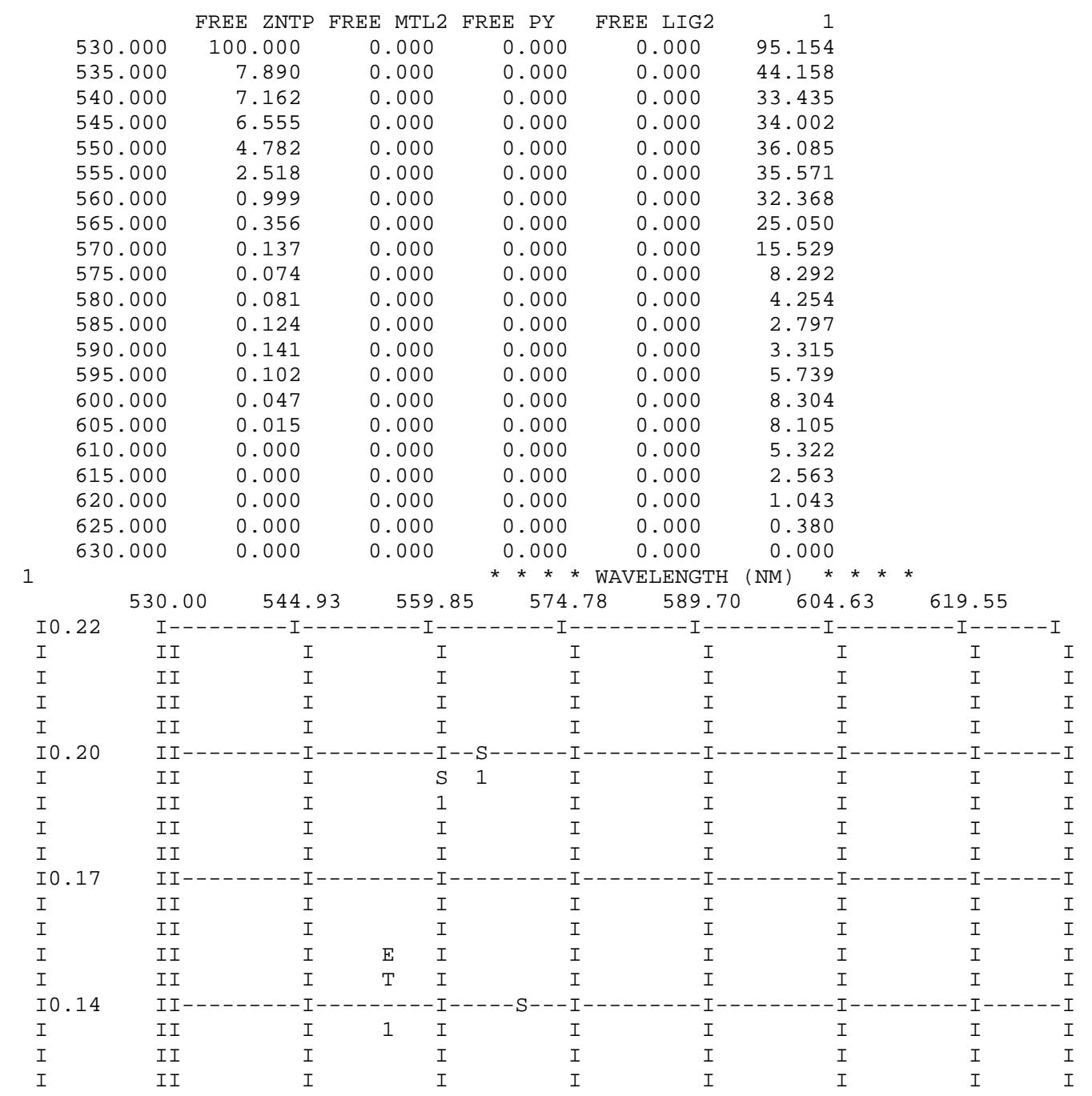






\section{STANDARD DEVIATION OF ABSORBANCE FOR SOLUTION $4=1.6333 \mathrm{D}-03$}

RESIDUALS FOR SPECTRUM NUMBER 4 POINT-BY-POINT

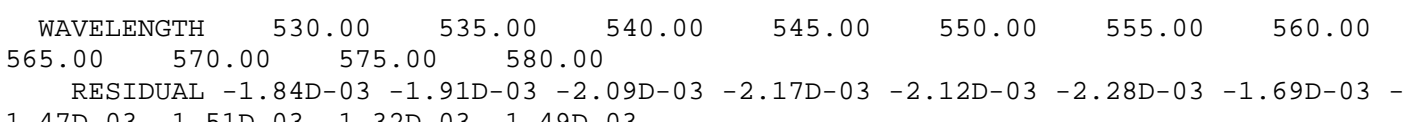
1.47D-03-1.51D-03-1.32D-03-1.49D-03

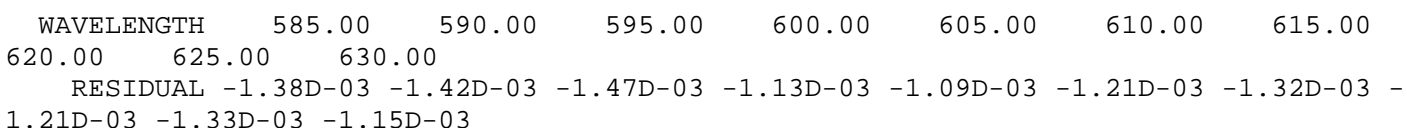
$1.21 \mathrm{D}-03-1.33 \mathrm{D}-03-1.15 \mathrm{D}-03$






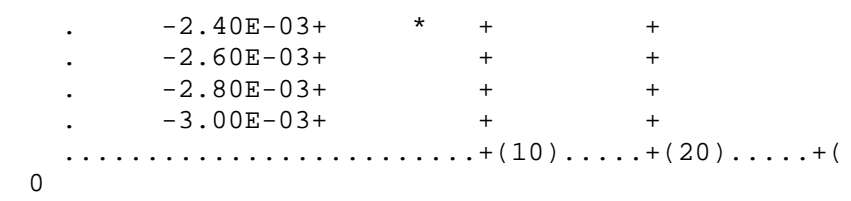

PERCENT CONTRIBUTION TO CALCULATED SPECTRUM NUMBER 4 FROM EACH SPECIES PRESENT IN SOLUTION






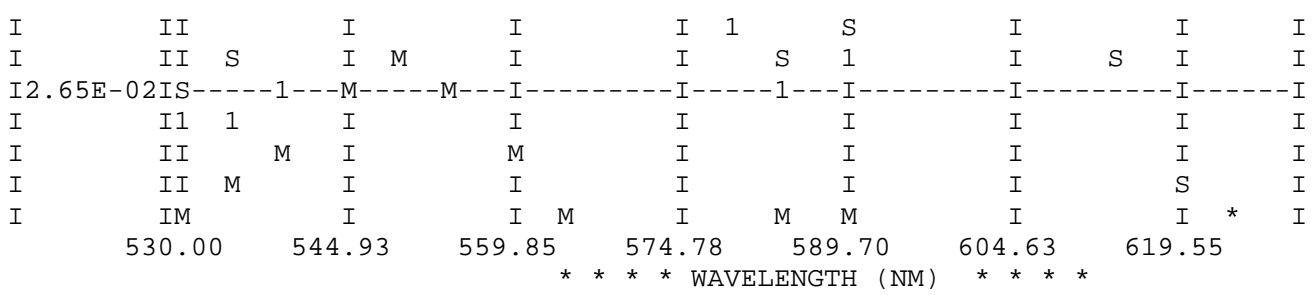

STANDARD DEVIATION OF ABSORBANCE FOR SOLUTION $5=1.9179 \mathrm{D}-03$

RESIDUALS FOR SPECTRUM NUMBER 5 POINT-BY-POINT

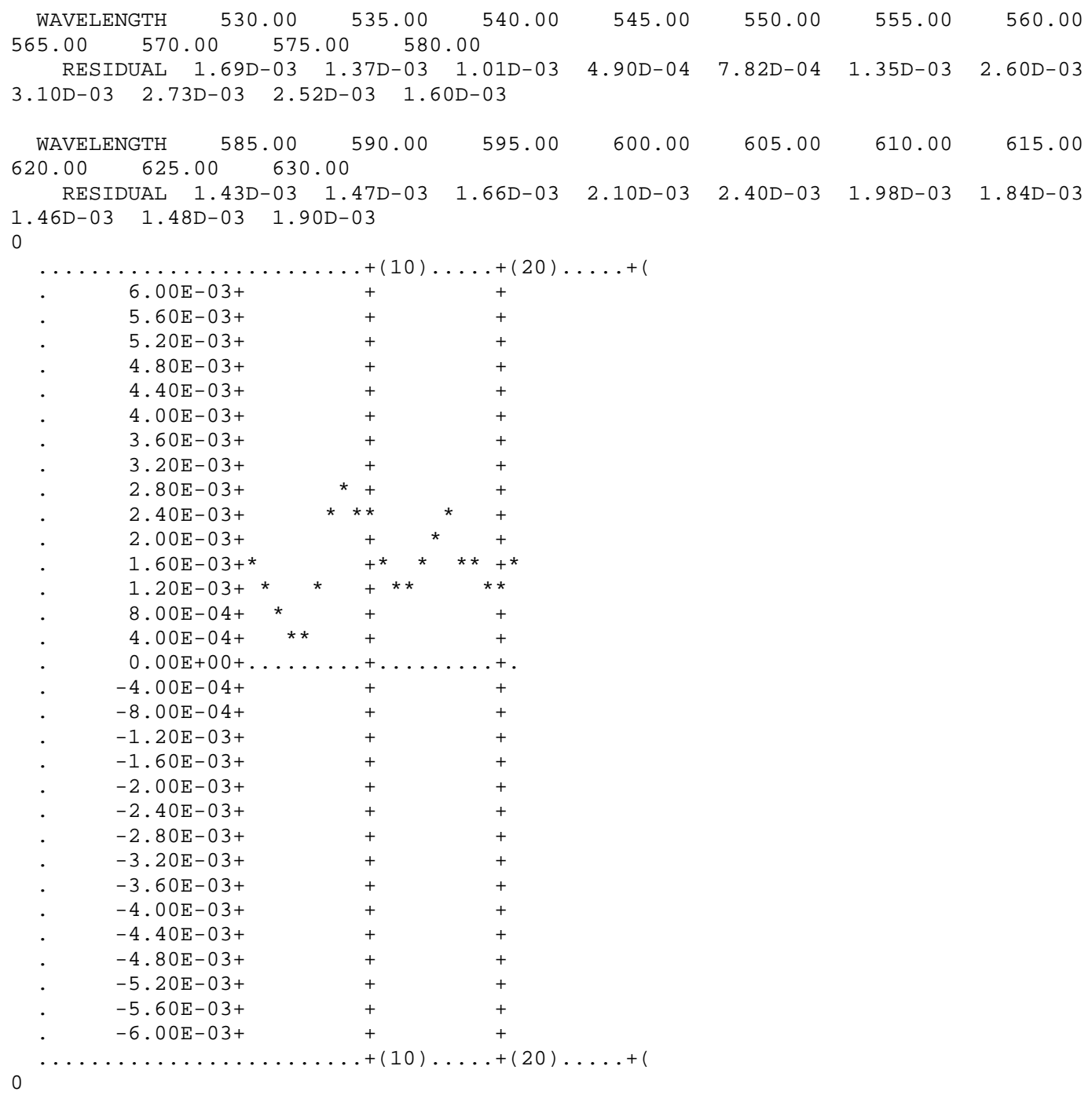

PERCENT CONTRIBUTION TO CALCULATED SPECTRUM NUMBER 5 FROM EACH SPECIES PRESENT IN SOLUTION

$\begin{array}{cccccr} & \text { FREE ZNTP } & \text { FREE MTL2 } & \text { FREE PY } & \text { FREE LIG2 } & 1 \\ 530.00 \odot & 10 \odot .00 \odot & 0.00 \odot & 0.0 \odot \odot & 0.0 \odot \odot & 79.362 \\ 535.00 \odot & 26.729 & 0.00 \odot & 0.00 \odot & 0.00 \odot & 34.410\end{array}$




\begin{tabular}{|c|c|c|c|c|c|}
\hline 540.000 & 23.486 & 0.000 & $\odot .000$ & $\odot .00 \odot$ & 24.391 \\
\hline 545.000 & 20.718 & $0.00 \odot$ & $\odot . \odot \odot \odot$ & $\odot . \odot \odot \odot$ & 24.178 \\
\hline $55 \odot .0 \odot \odot$ & 15.424 & $\odot .00 \odot$ & $\odot . \odot \odot \odot$ & $\odot . \odot \odot \odot$ & 26.286 \\
\hline 555.000 & 8.767 & $\odot .00 \odot$ & $\odot .00 \odot$ & $\odot .00 \odot$ & 27.346 \\
\hline 560.000 & 3.811 & $\odot .00 \odot$ & $\odot . \odot \odot \odot$ & $\odot .00 \odot$ & 26.334 \\
\hline $565.0 \odot \odot$ & 1.463 & $\odot .00 \odot$ & $\odot . \odot \odot \odot$ & $\odot . \odot \odot \odot$ & 21.191 \\
\hline $57 \odot .0 \odot \odot$ & $\odot .591$ & $\odot .00 \odot$ & $\odot . \odot \odot \odot$ & $\odot . \odot \odot \odot$ & 13.406 \\
\hline $575 . \odot \odot \odot$ & 0.325 & $\odot . \odot \odot \odot$ & $\odot . \odot \odot \odot$ & $\odot .00 \odot$ & 7.224 \\
\hline 580.000 & 0.358 & $\odot .00 \odot$ & $\odot .00 \odot$ & $\odot .00 \odot$ & 3.717 \\
\hline 585.000 & $\odot .550$ & $\odot .00 \odot$ & $\odot . \odot \odot \odot$ & $\odot .00 \odot$ & 2.442 \\
\hline $59 \odot .00 \odot$ & 0.628 & $\odot .00 \odot$ & $\odot . \odot \odot \odot$ & $\odot . \odot \odot \odot$ & 2.893 \\
\hline 595.000 & 0.451 & $\odot .00 \odot$ & $\odot . \odot \odot \odot$ & $\odot . \odot \odot \odot$ & 5.028 \\
\hline 600.000 & 0.211 & $\odot .00 \odot$ & $\odot .00 \odot$ & $\odot .00 \odot$ & 7.340 \\
\hline 605.000 & 0.067 & $0.00 \odot$ & $\odot .00 \odot$ & $\odot .00 \odot$ & 7.228 \\
\hline 610.000 & $\odot . \odot \odot \odot$ & $\odot .00 \odot$ & $\odot . \odot \odot \odot$ & $\odot . \odot \odot \odot$ & 4.774 \\
\hline 615.000 & $\odot . \odot \odot \odot$ & $0.00 \odot$ & $\odot . \odot \odot \odot$ & $\odot . \odot \odot \odot$ & 2.305 \\
\hline 620.000 & $\odot .0 \odot \odot$ & $\odot .00 \odot$ & $\odot . \odot \odot \odot$ & $\odot . \odot \odot \odot$ & 0.939 \\
\hline 625.000 & 0.000 & $\odot .00 \odot$ & $\odot .00 \odot$ & $\odot .00 \odot$ & 0.342 \\
\hline 630.000 & $\odot .000$ & $\odot .00 \odot$ & $\odot . \odot \odot \odot$ & $\odot . \odot \odot \odot$ & $\odot .000$ \\
\hline
\end{tabular}

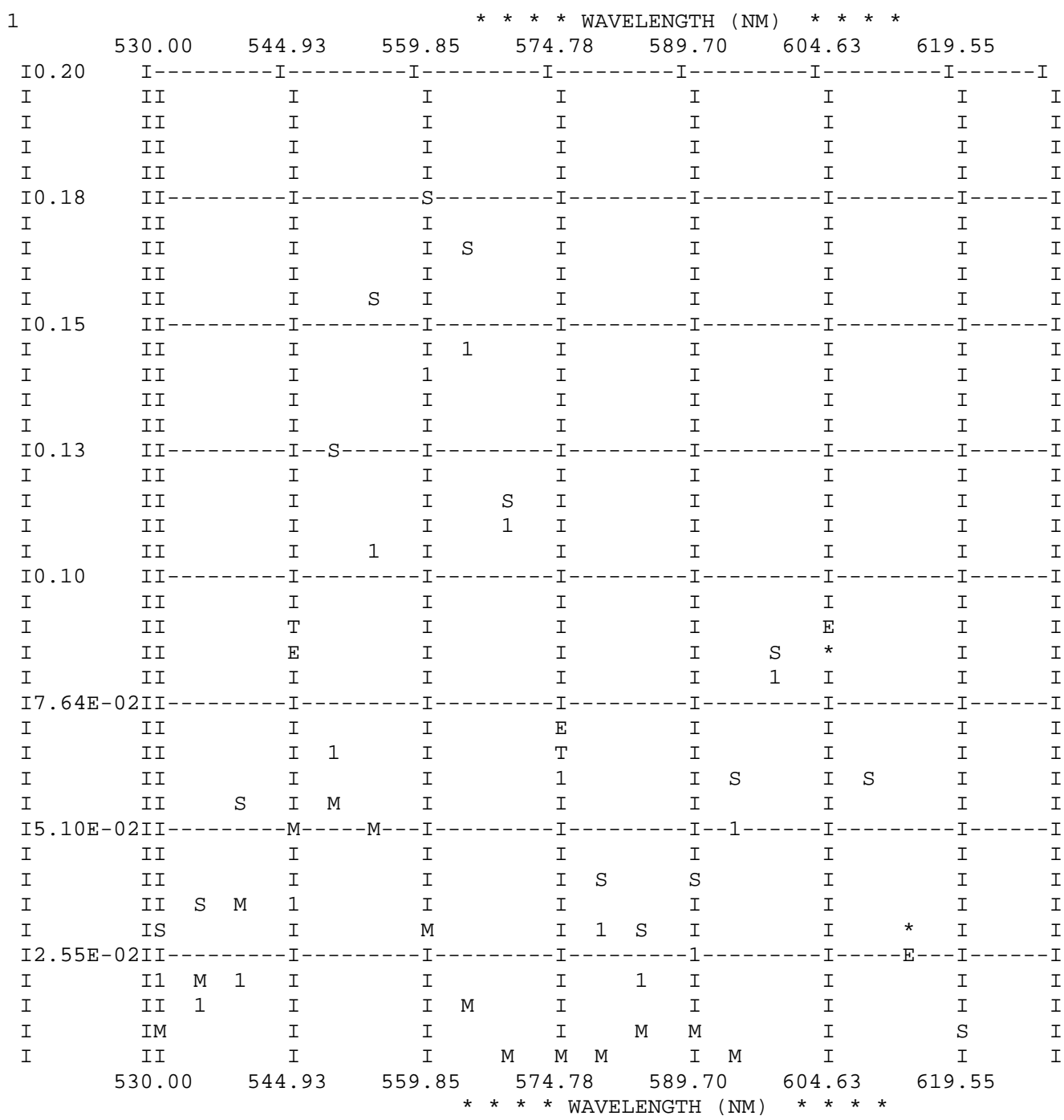


RESIDUALS FOR SPECTRUM NUMBER 6 POINT-BY-POINT

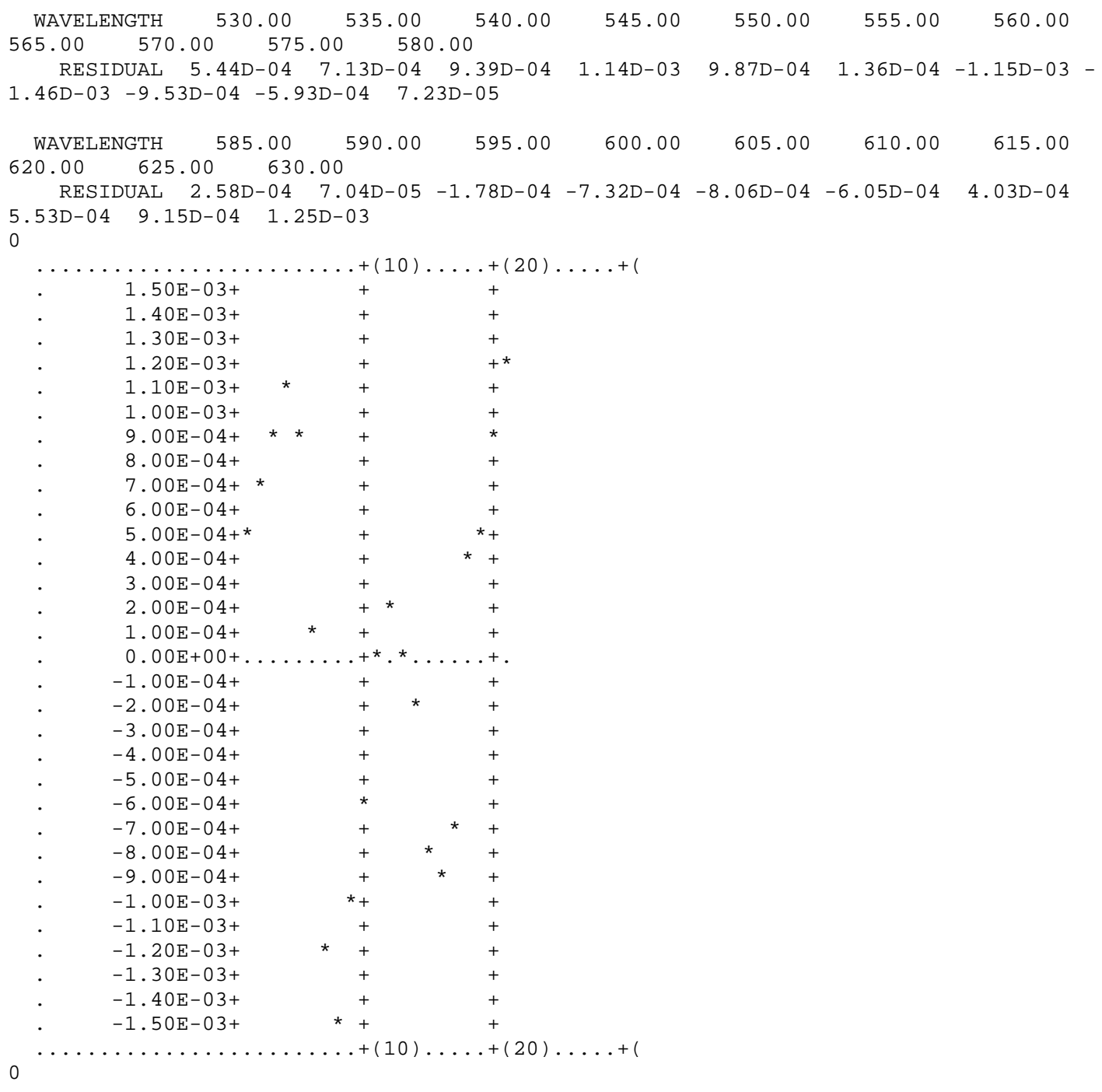
PRESENT IN SOLUTION

PERCENT CONTRIBUTION TO CALCULATED SPECTRUM NUMBER 6 FROM EACH SPECIES

\begin{tabular}{|c|c|c|c|c|}
\hline FREE ZNTP & FREE MTL2 & FREE PY & FREE LIG2 & 1 \\
\hline $100.00 \odot$ & $\odot .0 \odot \odot$ & $\odot . \odot \odot \odot$ & $\odot .0 \odot \odot$ & 65.323 \\
\hline 38.002 & $\odot .0 \odot \odot$ & $\odot . \odot \odot \odot$ & $\odot . \odot \odot \odot$ & 26.760 \\
\hline 32.765 & $0.00 \odot$ & 0.000 & $\odot . \odot \odot \odot$ & 18.063 \\
\hline 28.318 & 0.000 & $\odot .00 \odot$ & $\odot .00 \odot$ & 17.595 \\
\hline 21.316 & $\odot .00 \odot$ & $\odot . \odot \odot \odot$ & $\odot . \odot \odot \odot$ & 19.447 \\
\hline 12.673 & $\odot .0 \odot \odot$ & $\odot . \odot \odot \odot$ & $\odot . \odot \odot \odot$ & 21.044 \\
\hline 5.860 & $\odot .00 \odot$ & $\odot .00 \odot$ & $\odot . \odot \odot \odot$ & 21.213 \\
\hline 2.383 & $\odot . \odot \odot \odot$ & $\odot . \odot \odot \odot$ & $\odot . \odot \odot \odot$ & 17.667 \\
\hline 1.002 & $\odot . \odot \odot \odot$ & $\odot . \odot \odot \odot$ & $\odot . ๑ \odot \odot$ & 11.389 \\
\hline 0.562 & $\odot . \odot ० \odot$ & $\odot . \odot \odot \odot$ & $\odot . \odot \odot \odot$ & 6.191 \\
\hline 0.625 & $\odot .00 \odot$ & $\odot .0 \odot \odot$ & $\odot .0 \odot \odot$ & 3.194 \\
\hline
\end{tabular}




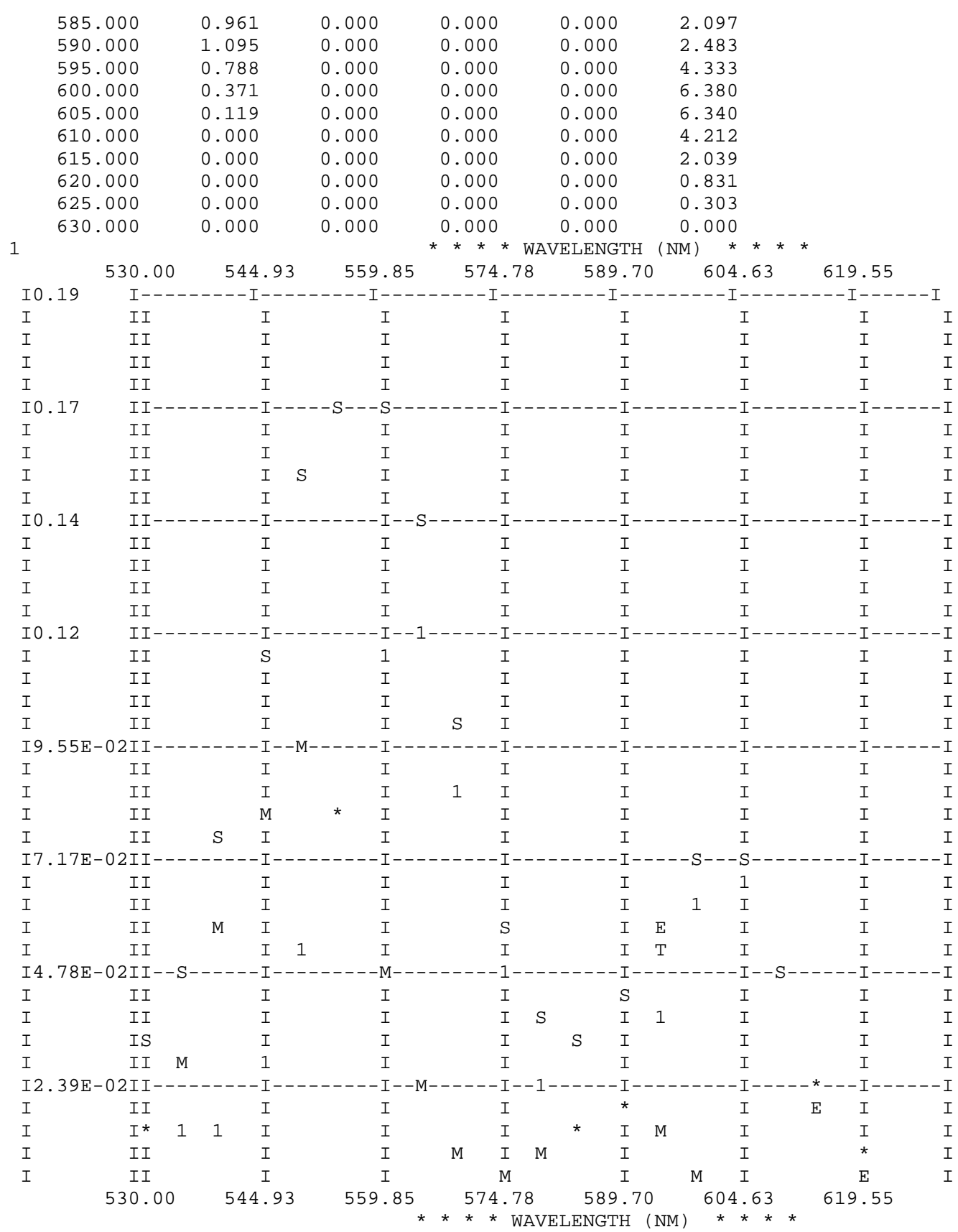

STANDARD DEVIATION OF ABSORBANCE FOR SOLUTION $7=7.0006 \mathrm{D}-\odot 4$

RESIDUALS FOR SPECTRUM NUMBER 7 POINT-BY-POINT






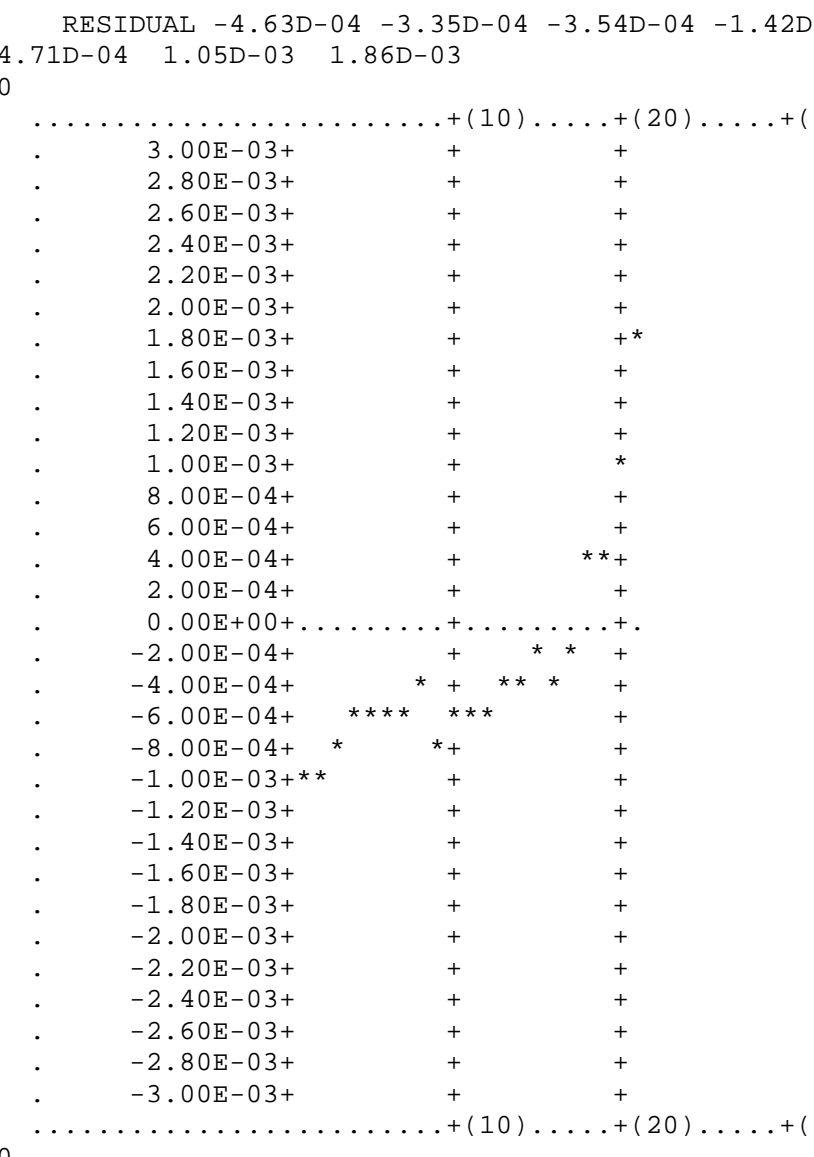

PERCENT CONTRIBUTION TO CALCULATED SPECTRUM NUMBER 7 FROM EACH SPECIES PRESENT IN SOLUTION

\begin{tabular}{|c|c|c|c|c|c|}
\hline & FREE ZNTP & FREE MTL2 & FREE PY & FREE LIG2 & $\perp$ \\
\hline $530.00 \odot$ & $100.0 \odot \odot$ & $\odot . \odot \odot \odot$ & $\odot . \odot \odot \odot$ & $\odot .0 \odot \odot$ & 47.796 \\
\hline 35.000 & 47.991 & $\odot . \odot \odot \odot$ & $\odot . \odot \odot \odot$ & $\odot .0 \odot \odot$ & 18.319 \\
\hline $4 \odot .00 \odot$ & 40.700 & 0.000 & $\odot .0 \odot \odot$ & $\odot .0 \odot \odot$ & 11.746 \\
\hline 545.000 & 34.580 & $\odot .00 \odot$ & $\odot .000$ & $\odot .000$ & 11.247 \\
\hline $550.0 \odot \odot$ & 26.270 & $\odot .0 \odot \odot$ & $\odot .000$ & 0.000 & 12.633 \\
\hline 555.000 & 16.246 & 0.000 & $\odot . \odot \odot \odot$ & $\odot .0 \odot \odot$ & 14.241 \\
\hline 560.000 & 7.976 & 0.000 & $\odot . \odot \odot \odot$ & 0.000 & 15.119 \\
\hline $565.00 \odot$ & 3.456 & $\odot .0 \odot \odot$ & $\odot . \odot \odot \odot$ & $\odot . \odot \odot \odot$ & 13.138 \\
\hline 570.000 & 1.525 & $\odot .00 \odot$ & 0.000 & 0.000 & 8.682 \\
\hline $575.00 \odot$ & 0.878 & $0.0 \odot \odot$ & $\odot .0 \odot \odot$ & $\odot .0 \odot \odot$ & 4.775 \\
\hline 580.000 & 0.989 & 0.000 & $\odot .0 \odot \odot$ & $\odot .0 \odot \odot$ & 2.473 \\
\hline 585.000 & 1.522 & $\odot .00 \odot$ & $\odot .0 \odot \odot$ & 0.000 & 1.622 \\
\hline 590.000 & 1.732 & $\odot . \odot \odot \odot$ & $\odot . \odot \odot \odot$ & $\odot .0 \odot \odot$ & 1.919 \\
\hline 595.000 & 1.248 & $\odot .0 \odot \odot$ & $\odot .000$ & $0.00 \odot$ & 3.368 \\
\hline 600.000 & 0.593 & $\odot .0 \odot \odot$ & $\odot .0 \odot \odot$ & 0.000 & 5.020 \\
\hline 605.000 & 0.192 & 0.000 & $\odot . \odot \odot \odot$ & $\odot .0 \odot \odot$ & 5.053 \\
\hline $610.00 \odot$ & $\odot . ๑ \odot \odot$ & $\odot . \odot \odot \odot$ & $\odot . \odot \odot \odot$ & $\odot .0 \odot \odot$ & 3.386 \\
\hline 615.000 & $\odot .00 \odot$ & $\odot . \odot \odot \odot$ & $\odot . \odot \odot \odot$ & $\odot .0 \odot \odot$ & 1.646 \\
\hline . $\odot \odot \odot$ & $\odot . \odot \odot \odot$ & $\odot .0 \odot \odot$ & $\odot . \odot \odot \odot$ & $\odot . \odot \odot \odot$ & 0.672 \\
\hline 625 & $\odot . \odot \odot \odot$ & $\odot .0 \odot \odot$ & $\odot . \odot \odot \odot$ & $\odot .0 \odot \odot$ & 0.245 \\
\hline 630.000 & $\odot .000$ & $\odot .00 \odot$ & $\odot .00 \odot$ & $\odot .00 \odot$ & $\odot .00 \odot$ \\
\hline
\end{tabular}




\section{INDEX}

A

Adler method, 15

Alkyl exchange, 8-10

Atropisomer, 3

Azaphosphatrane, 21-22

B

Basket handle porphyrin, 6

$\beta$-substituted porphyrin, 14

C

Caged porphyrin, 7-8

Capped porphyrin, 5

Cao, Yang, 9, 18, 45-46

Catalyzed Lindsey method, 17

Collman, James, 2-3

Computer-based determination of $K_{\text {eq }}, 33-34$

D

Dendrimer, 7

G

Graphical determination of $K_{\text {eq }}, 33-34$

I

Irreversible oxidation, 1

$\mathrm{J}$

Jurich, Jenna, 18

$\mathrm{L}$

Lindsey, Jonathan, 15-17

Lindsey method, 16-17 
M

Martinelli, Mike, 18

Meso-substituted porphyrin, 14

Metallation, 17

Momenteau, Michel, 6

$\mathrm{P}$

Proazaphosphatrane, 19-22

$\mathrm{S}$

$\mathrm{S}_{\mathrm{H}} 2$ mechanism, 8-10

Strapped porphyrin, 6-7

Stolzenberg, Alan, 8-9, 45-46, 49

Summers, Jack, 34

$\mathrm{T}$

Transannular bond, 21-22

U

Uyemura, Makoto, 7

$\mathrm{V}$

Van't Hoff plot, 38 